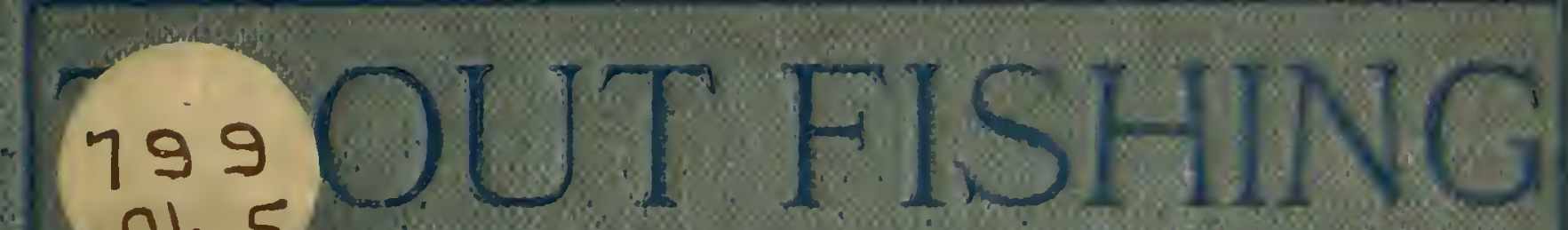
Sh 5 MORIESAND MORALS

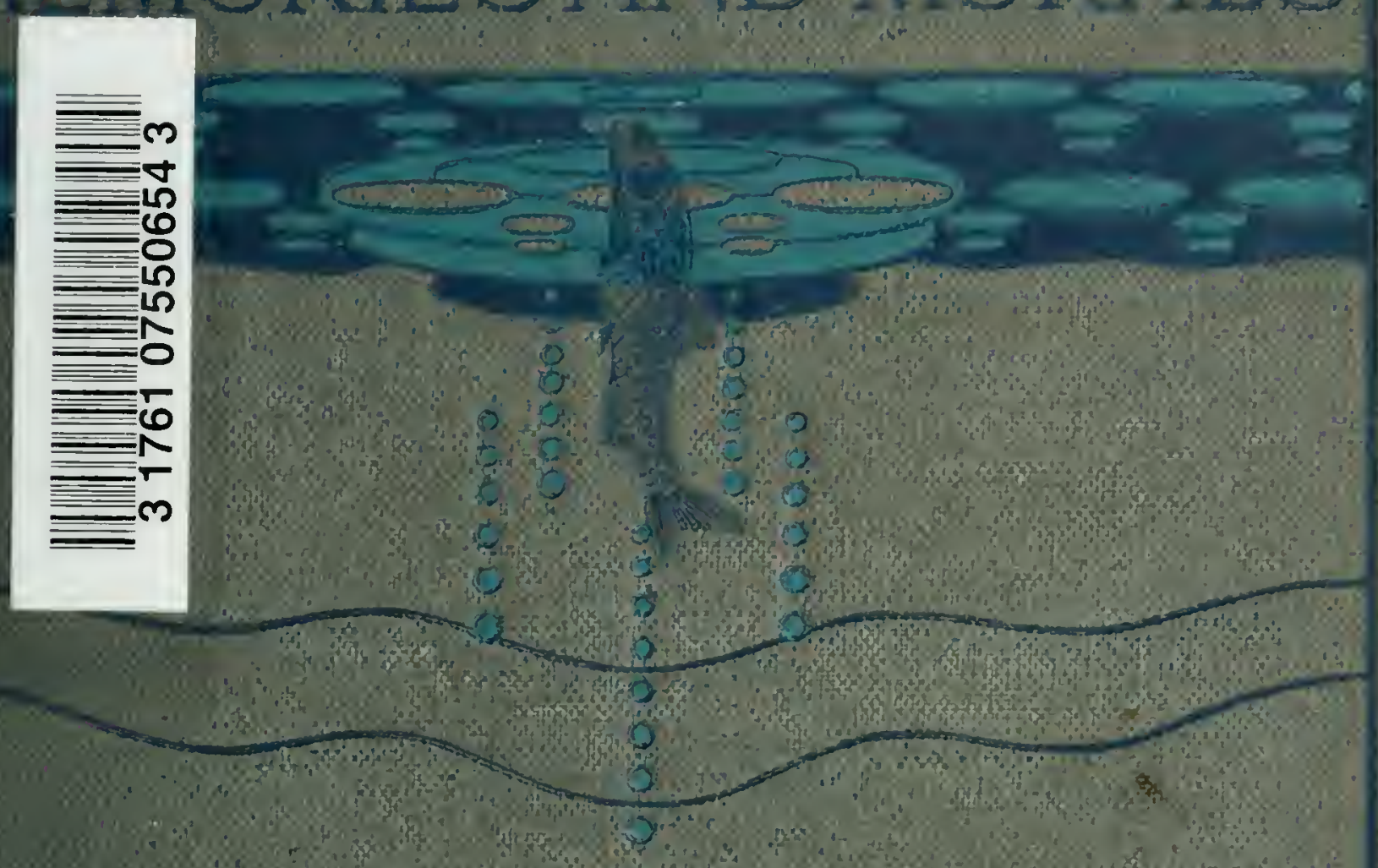

H.T. SHERINGHAM 


$$
195
$$




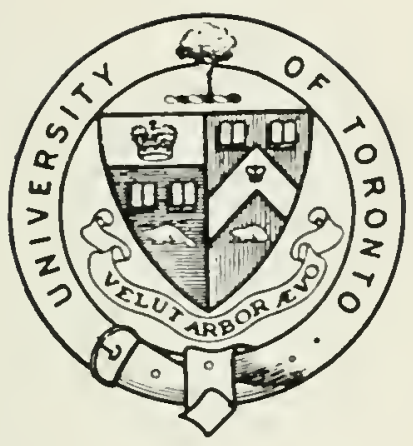

Presented to the

UNIVERSITY OF TORONTO

LIBRARY

by the

ONTARIO LEGISLATIVE

LIBRARY

1980 




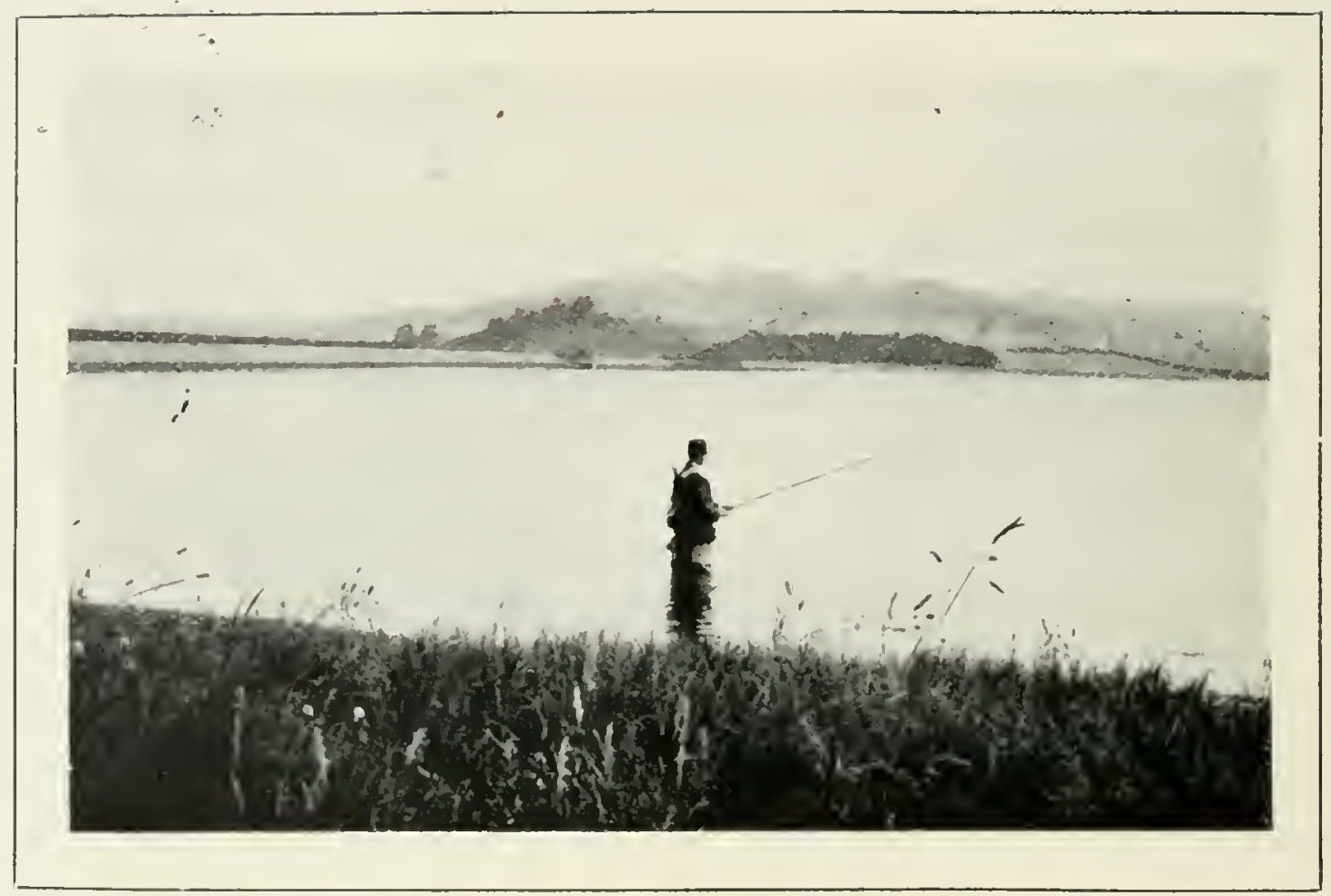

A Study of Hope at Blagdon 


\title{
TROUT FISHING
}

\section{MEMORIES AND MORALS}

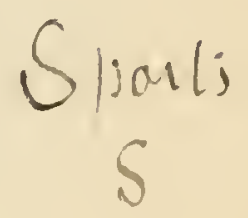

\author{
BY \\ H. T. SHERINGHAM

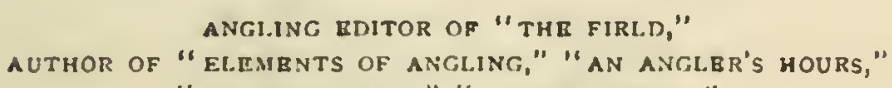 \\ "an OPEN CREEl.," "COARSE fishing," \\ "SVI.LABUB FARM," ETC.
}

HODDER AND STOUGHTON LIMITED

LONDON

16920 
$=$ 
TO

GUY c. POLLOCK

"We twa hae paidl't i' the hurn

From mornin' sun till diue ..." 
? 


\section{PREFACE}

The framework of this book was put together in the year 1915, the building of it being to a great extent a distraction from the stresses of war. For various reasons the book could not be completed till last year, when many changes had come about. So speedily, however, do things move nowadays that it now goes out into a world which is vastly different, not only from the world of 1915, but even from the world of a few months ago, and $I$ am in some doubt whether it should not have contained an appendix of trout-fishing economies-the wonderful priees achieved by split-cane rods, the kaleidoseopie ehanges in the ownership of lands and the waters thereof, the ridiculous new position of sixpenee, the inadequate size of fishing inns, the dearth of trout for restocking, and so on.

But I have decided that worthy handling of some of these interesting phenomena is beyond me, while others will receive adjustment at the hands of time and so do not call for special consideration. Henee I add no appendix.

The world, by the signs of the day, is turning, or being turned, upside down, and in a few years we may all be at the Antipodes of our former states, as old Sir Thomas Browne might have said. But it is some comfort to me that the real Antipodes are now very well furnished with trout. 
That being so, the figurative Antipodes will surely not be without them. The future, therefore, need not be wholly strange and alarming.

I find comfort, too, in another reflection. The number of anglers has increased prodigiously in a short year or two, and they will ecrtainly look after their own interests. That problem of ncw waters to which I give bricf and inadequate consideration in the fourtcenth chapter will no doubt be solved within the next generation. Obviously trout-fishers must fish somewhere. As for the rest of it a will must find a way. Here is a moral. Some of the prettiest little fly-rods I ever saw were made by a friend of mine out of the canes you use in gardening as supports for chrysanthemums and other herbage. The material for them cost about $2 s$. $6 d$. per rod all told. Now I suppose it would cost $5 s$. But we can save up.

Anyhow, come what may, even a tax on the air we breathe and a rise in the price of the dust in which we walk, we trout-fishers will somchow manage to go on fishing. And, if it be not indecent to say so, I hope we shall all go on reading books about the sport!

March 1920.

H. T. S.

Note.-I have to express my gratitude to The Field for permission to employ a good deal of material which I originally published in its columns, and to The Corntill Magasine for similar indulgence in regard to Chapter III. 


\section{CONTENTS}

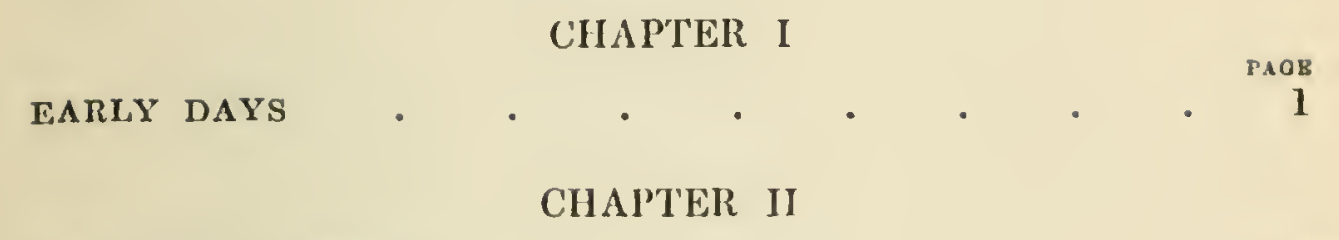

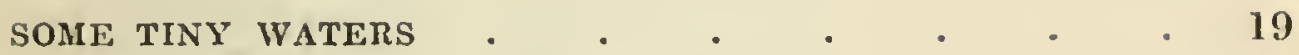

CHAPTER III

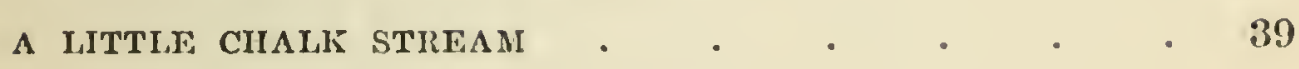

CHAPTER IV

THF FISHING DAY

CHAP'TER V

TIIE EVENING

\section{CHA I'T}
CHAPTER VI
CHAPTER VI

TIIE FLY QUESTION 
viii

\section{CONTENTS}

CHAP'TER XI

TIIE DUFFER'S FORTNIGHT •

CHAPTER XII

$\Lambda$ PECK OF TROUBLES • • . • • . • . 224

CHAPTER XIII

WEATIIER AND WIND . . . . . . . 251

CHAPTER XIV

NEW WATERS

CHAPTER XV

ODDS AND ENDS . . . . . . . . 283 


\section{CHAPTER I}

\section{E A R L Y D A Y S}

The confession is, perhaps, ignominious; but for some time after I first made the acquaintance of the trout I pursued it with what the law calls " engines." A set-line, a butterfly-net, a fishing weir or "obstruction," a landing-net-it is an unholy progression from bad to worse. There is, however, one sin which I have not upon my conseicnec, the sin of tickling. Proudly I can assert that never in all my days did I tickle a trout. In a lower tone, if any one insists on the point, I may add that $\mathbf{I}$ never succeeded in finding a trout that would abide the preliminaries to the operation. The fault no doubt was mine. But mine, also, is the honour. I find in the Fly Fishers' Club and other centres of efficiency that there is a certain distinction attaching to the man who has never tickled a trout. That he should have arrived at a fair comprehension of the dry fly without this previous training in subtlety is a somewhat notable thing. But he would never do for a chairman at the annual dinner. He would have nothing, or almost nothing, of which to repent him with tears in his voice. 
All the same, I remember that my fishing weir was an ingenious and effective thing. I built it on a tributary of the Tweed one foot wide, and afterwards applied the principle to a more considerable river in Gloucestershire which needed a bucket earnestly used in the after-emptying. But the net result of both engineering feats was only one trout about four inches long, the same which I had marked down in the daughter stream of Tweed, and which set me on the building of my dam. And at this time of day I will not swear that even that trout was not a parr. It had lovely red spots, and I tried in vain to keep it alive in some receptacle as a pet. The Gloucestershire foray was troutless, but not therefore a failure. What eels! My heart warms to the thought of them.

Dear reader, if you have never, at the age of nine or thereabouts, pursued an eel about the liquid mud of a nearly baled-out pool in a little Gloucestershire brook, you have, I assure you, never really lived. Shouting with excitement, a "mask of mud" (as old-fashioned domestics used to put it), you pursue the creature from corner to corner, from end to end, often getting a sort of grip of him, as often losing it. It is some time before you appreciate the inwardness of eel-catching, which consists in getting your hooked fingers under his middle where he balances and hoisting him promptly ashore. 
There your companion swiftly transfers him to a sack, that is if you are the master-mind. If not, if there is no great difference in ruling eapacity between you, your companion will probably be in the mud, too. And two eels out of the three will eseape over the lower dam. There is a third alternative which places you on the bank, but it is less dignified, and I will not dwell on it, even though it means an eel or so more in the narrative.

Besides, there will be quite enough ecls in the narrative ere I have finished. Onec in it, they are as bad to get out as they are in a nearly-baled pool. There was great plenty of eels in that part of Gloucestershire, and many a time did I set out to capture them from one of the insignificant ditehes into which they made their way. I used to wonder how they came there, for, take it all in all, it was a fishless part of the world. The brook I have mentioned, and two or threc ponds-I cannot remember any other waters close at hand whirh held anything. But in all the ditehes, however small, which contained water there were small eels, whose presenec I understand well enough now. The boundary of the county was not far away, and it was nothing less than the Severn, the greatest elver river in the land. It was tidal down there, to be sure, but doubtless the elvers ran up every streamlet which joincd it, and so made their way as far as they could get. 
There were two or three even in the Holy Well, a wonderful little pool of crystal water lying behind a bush on the right hand of the road as you go from the vicarage to the church. What a road to a child newly escaped from London! The very dust seemed to be sweet-scented. And there were dogroses in the hedges, and baby rabbits which you could very nearly eatch. But the eels were the greatest adventure to me. I could not cateh them either, the well being too deep. I remember them with affection, with the delightful dust and the dogroses. Referat si Jupiter annos!

To try and get back to somewhere within range of my subjeet-the eel is in my opinion almost the worst enemy that the trout has. Not nearly enough stress has been laid upon him by the professors of aquiculture. They have thundered against the chub and fulminated against the pike, but about the eel they have, for the most part, said little or nothing. This is probably because about the eel they know little or nothing. I do not know much myself, but very early in life and within a short half-mile of the Holy Well mentioned, I had an experience which taught me the abilities of the eel. There was an old fish pond which had formerly been made for a small monastic establishment, and was now the property of a farm. It was full of fish-carp and roach-and there was reason to suspect that it also 
held some pike-the disappearance of ducklings and other phenomena had to be accounted for.

With grown-up assistance I made an attempt to catch one of these alleged pike, using live roach which eame from the pond and such primitive tackle as was available. We got plenty of runs-in fact, it was a rare thing for the bait to be in the water for more than half an hour without being attacked. I had small knowledge of pike in those days, or I should have suspected the curious and vacillating bchaviour of the float, its bobs and dips and bricf inconclusive movements of a foot or two at a time. But, as things wcre, when, aftcr many runs which came to nothing, we succecded in landing a great cel of some three pounds, I was much surprised. We got others afterwards, but nothing much bigger, though one or two breakages suggested the presenec of monstcrs in the pool. What has remained in my mind chicfly, however, is not the sum total of success, but the broad facts of the ease. These were that the baits we used were not less than seven or cight inches in length, that the cels would attack them in broad daylight and also in mid-watcr, and, further, that this cannot have becn for lack of food because the pond, as I have said, was plentifully stocked with roach. All this proves conclusively, to my thinking, what a ravening creature the ecl is. I am not at all surprised that the cels of New 
Zealand, which grow to a weight of thirty pounds or so, have the reputation of being dangerous to human beings, seizing them by the foot as they swim, drowning them, and, later, devouring them piecemeal.

The trouble with the eel, so far as trout preservation is concerned, is that you may never know he is there at all. A friend of mine stocked a pool with yearling rainbows. They disappeared, and the misfortune was not unnaturally attributed to the habit of the race, which is to disappear. But it seemed odd that they should have answered to the call of the blood so young-as a rule they tolerate existence in an inclosed water till they have attained their fourth year. And, doubtless, they would have done so in this case also, but when the water was drained off on the chance of another solution, a colony of threc-pound eels was discovered, and it was evident where the little rainbows had gone to. In a river or a big lake the presence of eels may not be so much of a danger, but it is obvious that a small pool may be quite unfit habitation for trout until steps have been taken to eradicate the eels. How this is to be done depends on circumstances. If the water can be run off easily the eels can be got out wholesale. If not, night-lines and eel traps may gradually thin their numbers. Of course, the draining of the pond would be best, because it 
would serve a double purpose. The ecls would be abolished and, if the bed of the pool were left dry for a few months, a plentiful crop of weeds would spring up, and the trout when introdueed would start their carecr with splendid feeding grounds.

How are you to find out if there are eels in a pond? Obviously by setting half a dozen night-lines every cvening for a weck in July or August. Bait them with lobworm, and if there is no sign of a bitc and no eel on a hook at the end of the week you may pretty safely conclude that there are no eels in the water. It is not only ecls that may escape notice in a pool. I onee caught eight pike in a day, and ran a good many others, on a small lake in which, as every one supposed, there were only pereh and roach of no great size. On another day I got about a dozen eels there. Of course, the water had hardly ever been fished, or the pike, at any rate, would soon have been noticed, being rather visible objects when basking in hot weather or when on the feed in cold.

It does not follow that when you have abolished your cels you will have abated the nuisance for ever. Probably others will appear when the pond is filled up again. Elvers can creep in anywhere, and if that be not cnough, I have no doubt that mature ecls can and will travel overland on dewy or moist 
nights. There is no accounting for the presence of eels in some places unless this ability of landvoyaging be conceded. But even if the creatures do get back in time the trout will at any rate have had a fair start, and a chance of making enough growth to be secure from attack. I faney that eels in ponds do not gain weight so rapidly as trout, and a three-pounder has probably been in his pond for a considerable time. But it is risky to give opinions about eels. Their life-history is even less intelligible than that of the salmon, of which it is the diametrical opposite in the matter of migrations and breeding. Old big eels in fresh watcr are said to be barren, but that is not, to me, a very satisfactory solution of their long sojourn in fresh water. When you eome to think of it, it is hard to support a charge of barrenness against any fish at all. Habit of intermittent or deferred breeding, perhaps, but barrenness? The word is too lightly employed. I almost doubt if it is in Nature's dictionary, unless man's civilisation and man's fool-trieks have added it in the supplement of improvements.

Of late the cel has received much attention as a useful item in the national food-supply. I do not question his merits, even in opposition to some other fresh-water fish-roach, for instance. But if it eomes to weighing his importance against that of trout it is obvious that he is the less valuable fish. 
As a result of war there is a tendency now to calculate things in terms of market-supply, and there, it may be, cels make a braver show than trout. But the sporting factor counts for a great deal and, I hope, always will. There the trout has the advantage. After all there is plenty of room in this country for developing the ecl-fisheries very greatly without interfering with trout, so there is not likely to be any danger of a conflict of interests. But enough of ccls.

One of the bravest days that ever I had was on the same brook near the Severn Sea. Another boy and two landing nets formed my assistants, the other boy really being the prime mover. Oddly cnough, I have forgotten both his name and face, which is ungrateful of me, for he was a handy fellow with a net in a brook, and I believe he let me take all the trout-a dozen there must have been-home with me. I remember the fishing much more vividly than anything else, how we prodded under trec roots and sloping banks, and how ejected trout came with a thud into the waiting net. I remember, also, a little fall near the farm which we drew blank, and were much surprised thereat, until we discovered a sort of secret drawer at the back of the foam. Thenec eame the biggest trout of the day. I have always considered him a pound and a half. He bulked large among the others. 
I remember that day also, because some years later I sat down to immortalise it in what I considered prose, and because to my intense pride the result was actually published by _- , but I will not give the journal away for doing a kindness to me. I am sure the article must have been full of " spotted beauties," and "finny denizens," and "old Sol," and things of that kind. It should have joined my other early efforts in the waste-paper basket or the fire. But, under Providence, I believe it set me on the business of writing instead of some useful occupation, such as studying torts and turbary, whereby men rise to affluence and office.

I believe, also, that the day which it purported to describe made me for ever a lover of small streams rather than big ones, of odd corners rather than the open river. I love to find a trout cruising about with his nose just outside the scum at a hatch, I glory in a fish which lies with his head pointed the wrong way by reason of some back-wash, and if it is at any time possible to pursue a by-stream instead of the main river I pursue it. There is the additional reason that $I$ think the fish are easier to catch, and sometimes rather bigger, in the carriers, but there is a genuine affection for insignificance which moves me too.

Nearly forty years of angling give a man a host of memories, and I remember many tiny streams in 
the landscape of the past, all faseinating in their way, and some of them curious. There was one which meandered into the sea in a Pembrokeshire bay, tolerably well known now, but in those days a long way from railways and the general public. I do not remember ever catching a fish out of that stream.

It ran-at any rate, all of it which I exploredsinuously through the marshy flats and its banks quaked like anything. Even the most cautious approach to the water seemed to spread a panic among its inhabitants, and I could see their vanishing forms just leaving every corner when I got to it. The tragedy of it was that they were much longer than the forms which used occasionally to vanish before me in the proper river a mile away. Doubtless they were not very big fish, but very likely they may have averaged a quarter of a pound, which is considerable for that part of the world. Just often enough to keep my determination alive I got the pull of one, usually by dibbling a worm over the bank before I approached it, a proceeding calling for self-restraint. The pull would be full of vigour and impressive, but it never came to anything. I was a trout fisher then of the fortiter in re type, which scores no great suceesses in cireumstanees where subtlety is required. Besides, the exeitement of a bite after long disappointment 
no doubt made me previous as well as violent in striking.

It is curious how places and events are associated in one's mind with odd scraps of irrelevanee. When I was fishing that stream I was also every morning engaged in the business of constructing Latin verses under the eye of my dear old grandfather, whose chief ambition it was, so far as I was concerned, to make a scholar of me.

"Carpite dum liceat vos nymphæ scrta rosarum."

Never while I live shall I forget that rendering of Herriek's "Grather ye rosebuds while ye may." I think it must have becn my rendering after it had been "castigated," but I am not surc. It may have been a model line out of Arundines Cami, or one of the other authorities, in which ease I ought not to speak of it with disrespect. But the useful little word "vos" coming in so pat to ease the scansion reminds me of my own Latin verse policy, which followed lines of least resistance, especially when I thought of the trout in the stream with rush-grown, quaking banks. "Old Time is still a-flying." I am afraid I used cordially to endorse that statement many a morning in those lodgings by the sea. Time was flying, I thought, and though I was no amateur of roses I badly wanted to be gathering trout, which eame to much the same thing in point of philosophy. 
Boyhood has no prescience. What would I not give new for a morning's verse-making with the dear old gentleman, or even-which used to be perhaps, and would now be certainly, more terrifying-an hour or two of wrestling with the obscure and tedious narrative of Thucydides!

But in the afternoon, the tasks all done, I would ecrtainly make my way to that strange streamlet and endeavour to prove that the years which have robbed me of almost every particle of Greek have done something to improve my fishing. I think I know how to catch those trout now. It is a slow business, but it can be done. The angler has to grow into the landscape like a post or a willow tree. After a time the fish get accustomed to him and return to their places. Then he delivers his orange partridge or his blue upright with an underhand cast, and lo, the legend of their being uncatchable is disproved.

It is casy, you may say, to theorise when one is safe removed from an cmergency by many years and much country. And so it is. But it is not all theory. I have proved this waiting game often cnough, and in all kinds of watcr. 'The shallows of a tiny brook, the sluggish reach with quaking banks, the dead unruffled flat-such places are often a secne of tumult on an angler's approach, and long ere he can extend enough line to cover them. His 
policy in each case is to select a point of vantage and wait there till the trouble is over. It wastes time no doubt if he is for filling the creel, and he might do better in point of numbers if he sought easier places. There is, however, a great satisfaction in solving a problem.

I have often chuckled at the theologian who, meeting a difficulty, looked it boldly in the faceand passed on, but I can seldom emulate him in trout fishing. I always have to prove that the difficulty is my master before I can pass on. Sometimes, of course, there is a happier issue to the contest. Therc was once a singularly perfect cast which I made on the Windrush in Mayfly time. A good trout was rising in a ficndish place, between two willows which both drooped into the water, and under a low bough. My fly evaded the willows, shot under the bough, and floated beautifully over the desired spot, the amount of slack line required having been calculated to a nicety. "Ah," said my friend and host, "if only that had happened ten casts ago!" There had been previous attempts, I must own, and perhaps even a little splashing. The trout, for all I know, is still in the same holt.

Of another tiny stream I have also an oddly detached memory which is associated with a regret. It, too, was on the coast, running into the sea within view of the Isle of Wight. I had fished it for a 
fortnight on and off during tropical weather and had had remarkable sport considering everything —one of the things to be eonsidered being that it was apparently a discovery on my part that it held trout at all. The particular memory, however, is not so much of the fishing as of a notable thunderstorm which raged the whole of one night. We were awake for hours watching the lightning as it played about the Needles, a wonderful sight. It was not, however, this impressive display alone that kept me awake, it was the thought of the fishing which would follow such welcome rain. I made sure of a day which would beat all my previous records and which would prove my theory correct that a brook but a yard wide may contain pounders and better if you put it to the proof. Alas, I never did put it to the proof for unexpected events made it necessary for me to depart on the day after the storm. I think I had touched fourteen ounces, however, which was something.

I have another odd memory of the same stream. One day as I was following it up, fly-rod in hand, I came on another youth of somewhere near my own age who was engaged in a queer form of fishing. He was apparently employing expensive gut casts as set-lines, and scemed to have adorned each with fragments of cork. He had no rod, and I came to the conclusion that he was the sort of individual who 
would be a poacher if he knew how, but who, fortunately, did not know and would have some difficulty in learning. I scorned him silently and passed on. Oddly enough, some years later, I traced this amateur poacher in a valued friend of later date, and found that he retained a memory of an offensive person with a fishing-rod who had once passed him on the side of that little stream. A casual naming of the locality made the incident leap to both our minds. My friend certainly is no fisherman, so my early instinct had been correct. But it was a good thing that I did not give expression to it, for he has ever been a singularly capable boxer, and my first introduction to him might have been less propitious than it was.

One learns something new from every fresh water one visits if Fate is at all amiable. I remember one lesson which that streamlet taught me, I think for the first time, the lesson that sometimes one must depend entirely on the sense of touch for notice of a risc. There was a deep run under a high bank (of course, to bring the water " to seale" I ought to insist on inches rather than feet), and it turned a sharp corner at the bottom end. Two or three times I had spoilt my chances there by trying to see over the bank as I fished, to the great consternation of the half-pounder which I yearned to eatch. At last I decided that I must cast round 
the corner upstream at a venture and tiust to luck for the issuc. This plan succeeded. I do not know how I became aware that something was withholding my black gnat from me, but I did become aware of it, the rod went up, and the halfpounder in due course was mine. After more than twenty years that fish still gives me a thrill of satisfaction.

In those days I had not yet come to the dry fly so the black gnat was fished wet, but sinee then I have occasionally had a similar experience with a floating fly. It is, however, much harder to detect a rise round a corner in dry-fly fishing unless you can hear it or catch sight of the advance party of the betraying rings. I do not pin much hope on a round-the-corner attack as a rule. With the wet fly there is more chance. The line is, or should be, fairly taut from the rod-point, which is raised as the fly comes downstream, and when a fish takes the fact may be notified by a check to the line, or possibly by a definite sensation of stoppage which is perceptible to the hand. A very slight thing ought to be perceptible if an angler is on the alcrt, and though he possibly could not express it more exactly than by saying that "something is different somehow," it has enough effect to make him strike, which is all that is wanted. The scnse of touch is much more delicate than most people suppose, and it 
may even be possible that a small vibration is set up from the fish to the hand, enough to give warning of a rise without the need for anything so definite as a pull. Often one knows, just too late, that a trout has been at one's fly though one has never seen or definitely "felt" the attack. 


\section{CHAPTER II}

\section{SOME TINY WATERS}

IT would take me several volumes to record at all adequately my gratitude to the lesser streams which have given me delightful days in various parts of the country. Some of them have wandered slowly through the heavy land of the Midlands, and their trout have been few and far between, but all the more prized for that. When the worm-for I take no shame in owning to the worm for some of these brooks-has been cannily dropped through the opening between the thorn branches, has trickled down the narrow neck into the little round pool, and then come to rest, there is a time of anxious expectation before you decide that the pool is tenantless, and that you had better go on to the next likely spot. Or you may have the good fortune of an almost immediatc bite, which takes the form of a preliminary twitch, another, and then of a steady pull, which makes the line cut the water as the fish moves off with the bait, probably taking it back to the retreat whence he emerged. If you strike when he is fairly on the run with it you ought to have him, 
especially if you are using Stewart or Pennell tackle, though I must own that, as a rule, I have found two hooks somewhat too many for these brooks, which are apt to contain far more snags than trout.

They sometimes contain other things, too. The very last time, I think, that I fished such a streamit was not long before the war began--my day's fishing yielded one small dace, a ridiculous eel, and a fat minnow. The last was the result of much patient work in a very promising pool under a willow. I was induced to persevere by occasional twitches at the rod-point, which suggested a trout of vacillating disposition-I have known plenty of fish like that in free and unpreserved waters-but in the end the minnow somehow got attached to the hook, though it was rather a large one. After that of course I fished with him, but it was of no avail. But for a momentary glimpse of a three-quarterpounder, which fled from a shallow corner at my approach, I had no experience of trout that day.

Yet it was by no means a day wasted. I counted, as I fled from, at least a dozen wasps' nests. I had a leisured lunch in the sun on a comfortable sheepbridge, and all the time I gloried in the minuteness of the stream. It was no more than six fect wide anywhere, and it made me a boy again for the time being. As I came to each pool in turn I had the 
old thrill of exeitement. "There must be a trout here. If I can only dodge that bramble and get the worm under the root...." The mental process will be the same if one lives to be a hundred and is still capable of angling then.

I have, of course, often wished that these odd neglected little brooks had been rather better supplied with fish, and yet I am not sure that their very poverty is not part of their attraction. If one could be sure of pulling a half-pounder out of cvery pool the pursuit would, perhaps, lose some of its zest. But when thirty pools yicld no more than three bites or other signs of fish, a trout becomes an event. "I got two trout from the brook on Tuesday," you will say in a tone of studious modesty, and the other fellow will return a "Did you, though?" which is more than a little gratifying.

This is not the best conceivable state of such a brook, of course, and if I had the opportunity of dealing with one freely I should make an carnest cndeavour to improve it and make it into a fly-water of an amusing, if insignificant, kind. Very much could be done in this way by introdueing suitable weeds-a property in which many such streams are lacking-cutting bushes and boughs, though not too lavishly, and clcaring the pools of some of their rushes and other uscless cneumbrances. Here and there small dams would be uscful, here and there a 
few minutes with a spade would improve the tiny shallows; here and there it would be a good thing to remove some mud. When one had worked faithfully for a week or two it would pay to introduce some more trout, yearlings if one had patience to await their growth. And in the end, with a small rod and, say, a ten-inch limit, one might have very pretty sport and occasionally capture a fish of good size. On the brooklet where my chief capture was the minnow some one once had a four-pounder, and several have been taken over two pounds. The stream is certainly one of the smallest which optimism could associate with trout at all.

I do not know how many small trout streams of this kind there are in the flatter portion of England, but I think they must be quite numerous, a large proportion of them being hardly realised. Travel out of London in any direction, and you will sce frequent lines of willows which mark the course of some streamlet of the same type. It may, of course, be polluted and useless, or it may be too nearly allied to some coarse-fish river to give the nobler species a chance. But in, I believe, the majority of cases every such brook is potentially a trout stream and capable of giving sport of a kind not to be despised. For the moment, of course, I speak of districts away from the chalk. In the chalk districts the trout-bearing possibilities of 
every rill are well enough understood. The sparkling water is in itself a proof of them.

But the brooks of the elay and other less promising loealities look more like the sluggish rivers which they ultimately join, and suggest bream and cels. Unless, therefore, a man has by some chance discovered that they may hold trout, it would not occur to him to study them with that object. They are bound to be found out and developed in time, since the demand for trout fishing in accessible places is much greater than the present supply, and the man who onee tries it will probably find that the sport provided by such streamlets has features of its own which are not to be matched in any other kind of water. The very difficultics of fishing, which are often immense because the water is nearly always much bushed in places, are an attraction. Possibly the survival of the trout at all in a brook of the kind is due to this growth on the banks. It is worth remembering that herons are rather shy of the much-bushed parts of little streams. Herons ean play the mischief with trout which have no protection. From the fishing point of view I would always have a brook pretty difficult. "Plenty of fish, but very hard to eatch" is, it seems to me, a very good character for a small stream to have.

The description of a day on another brook, slightly 
bigger than that which yielded me a minnow, a dace, and an eel, and much better furnished with trout, may be worth giving, since it illustrates some of the difficulties which attend the brook-fisher.

"Difficulties," I said to myself airily, "add to the fascination of angling. This stream was quite beyond me last time, but now I'm prepared for it and know what to expect." Last time had been five years before and a rod of ten feet three inches had been greatly prejudicial to success. For the brook winds along like a very sinuous serpent between lofty banks on top of which is an almost unbroken succession of trees and bushes. It presents a delightful little pool at every corner with a pretty little ripple running into every pool, but all my efforts had failed to get a trout out of it; though several had come at a cochybonddu, when I managed to get it onto the water after many struggles, all had kicked themselves off before I had made up my mind how to get them out. I came home "clean," and with a great respect for the accomplished angler who, as I had been told, always managed to get a dish whenever he visited the place. I had noted his traces here and there in the clearing that had been done. It was enough to make some of the pools approachable for a very clever fisherman with a very little rod, but it was of no use to a bungler with more than ten feet of split cane in his hand. 


\section{SOME TINY WATERS}

At my second visit I was more suitably armed so far as the rod went, a little gem of seven feet which was really the result of that earlier experience. Though I had not had to fish such a stream since, I had determined not to be found unprepared in the event of such an opportunity coming my way. And meanwhile, on more open though equally small waters, I had tested the tiny rod's qualities and found them most satisfactory. So, if the rod could do it, the stream was going to learn who was master. There was about threc-quarters of a milc of water at my disposal (so curly that a straight line from top to bottom would be but 600 yards or so) and I determined to get in at the bottom and fish upstream wet or dry as circumstances might suggest. Here and there it might be too deep to wade, in which case I could clamber out and start again above.

I began "as per programme," having solved the problem of reaching the water at the boundary by tobogganing involuntarily down the high bank and entering the stream with a splash and a severe shock to my system. Whilc I was recovering from the resultant palpitations I was startled by the sound of some great animal rushing down upon me. "The bull," I ejaculated in horror and surprise. For I had, as I thought, located that animal two mcadows away, and had very carefully left him undisturbed. 
The gates were open but I had hoped he would stay where he was. So far as I know he was staying there. It was not the bull, but merely the bank, which had caught the infection from my example and was tobogganing on its own account.

I then felt a nervous desire to imagine the sort of story Mr. Algernon Blackwood or Mr. Hope Hodgson might make out of the incident. There is a pool on a salmon river of my acquaintance which is called "Sliding Braes," and it occurred to me that a peculiarly frightful ghost story might be hung onto such a name. Imagine the angler, in the gathering dusk, pursued by a bank! "And then, in that extraordinary hush, which I can only describe as a vortex of silence in which I was the helpless centre, I knew that something was going to happen Looking up from where I was, waist-deep, I saw as it were an undulation, an expanding and contracting of the solid clay that frowned down upon me. Frowned-that is the word. It was literally a frown. If you can imagine eycbrows twenty yards long! What happened afterwards I shall never clearly remember. That portentous face scemed to grow upwards and outwards. It bulged at me as you may have seen the face of Acolus bulging in old prints. Great swollen cheeks! And then came the sliding down. The great slab lips ..." 
However, I am not telling the story of Sliding Braes, if there is one, and I had better get on to what I am telling. The first pool, one of the best on the water as I had been told, was too much shaken up by the violent approach of me and the bank, so I made as if to wade through it, so that I might approach the next. But it was just too deep, and I had to clamber out again at once, no light job. I began to realise that the atmosphere was oppressive and thundery, when I found the net clinging to a briar and the rod entangled in a low-hanging oak bough. Eventually, however, I was up and out and able to descend, a second time, above the pool. Then I began my fishing.

The manner of the fishing was this. Crouching as low as possible $I$ got into position for the glide at the tail of a pool in which instinct assured me there would be a half-pounder waiting all ready for the cochybonddu. It might be a matter of four yards away. So far arrived I began to lengthen line for the cast. When line was about half lengthened there was a hitch. The cochybonddu had come to rest overhead. At that moment I saw my half-pounder. He was procecding upstream, to vanish beneath a root under the left bank. Drawing myself up to full height (as they do in the novels, but seldom, I warrant them, with such relicf to the smalls of their backs) I eaught hold of the line 
and tugged, first gently, then with more determination. Later I looked out a fresh cast and a clcan cochybonddu. After these delays I canac to the ripple at the head of the pool, got a fly onto it at the twelfth attempt and was rewarded by the sort of "wink under water" that recalls the proverb Ars longa trutta brevis, which means, the longer you take to cover a fish the shorter he rises.

The next pool was round a corner. I prospected with one eye (no more) and had the pleasure of sceing scurrying forms. Nothing more happened there, for it was only a small pool and they scurried all over it. Above was a short stickle and then deep dark water on which I could sce beautiful spreading rings often repeated. I could hear the "plopping" of a really noble trout. Nothing under a pound makes all that noise. But these manifestations were happening in the middle of a bush. Not only could a fly not be got into it; it even stopped the onward progress of a by now infuriated angler who had to clamber out of the ravine once more.

How often I got in and out during the next quarter mile I do not know. It was very often. Now and then a pool was too deep to be passed, now and then it was choked with boskage, now and then a fallen tree lay all across it. One thing had become 
disconecrtingly plain. The clever angler had done no clearing this long while. The stream had been difficult enough five years before. Now it was appalling. I shudder to think what it cost me in cochybonddus. Occasionally I got the fecblest kind of ofier from some fish whose isolated position prevented him from knowing about the panic which possessed all the others. But the sort of rise he made proved that there was suspicion in the air. The whole business was of course aggravated by the impossibility of casting what you could call a line. The trees and bushes were so thick and mostly hung so near the water that the only method by which a fly could be got out was by "catapulting" it. And that can only be done with quite a short line. I had one consolation such as it was. The periodical thunder showers that enlivened the earlier hours came at me viciously but quite in vain. Not theirs the power to penetrate the jungle in which I crept.

It would be about 3 p.m. that I decided that I was beaten and climbed heavily out to the upper air. I would have no more of that sub-silvestrian foolishness. I would go home and say that there was thunder in the air, on which account the fish were out of humour. As I went I would look into such pools as were approachable and sec what might be seen. I approached the first and gazed boldly 
down into it. There was a trout immediately below me, and we were apparently looking at each other. Sardonically I plumped the cochybonddu down onto his nose. He took it. I pulled him out of two bushes and a hole and swung him up the precipice into the meadow. He was quite half a pound. This occurred again a little higher up, and I had a bracc. Presently I had two brace. And then I sat down on a knoll overlooking a half-moon shaped pool two yards and a half wide and five or six yards long. Comfortably and leisurely I dibbled three more here. And from a pool just below it I got a beautiful pounder. I should mention that I happened to have a worm with me, and I may as well confess that there was another worm as well and that another fish fancied it. But all the others were caught on the artificial fly, if it can still be so called in spite of the manner of its presentation. If it had not been for tea time I am confident that I should have got the catch up to double figures. There may have been a third worm in the tin. Also I had found myself the brook's master in spite of everything.

But how or why it happened like that I cannot explain. I had another day there afterwards, pursued the same bold policy of the successful afternoon, and terrified the trout into non-existence. Just one fish rewarded me and for him I crept and 
crawled most abjectly. It is a very queer little brook indeed.

Mostly, as I have hinted, I have found the worm the best and easicst bait for the brooks. The artificial fly may be of service in places, but it is much more limited by the geography of the stream. Probably, if you stick rigidly to the fly, you will have to leave a good half of the water untouched, since you simply cannot get a fly to it. A worm, however, can be insinuated into almost any nook, and, if not, it can be swum downstream with the aid of a small float. Other methods of getting at the fish are dapping with a bluebottle, grasshopper, or other handy insect, and drop-minnow fishing. Both are more artistic than worm fishing, but dapping may be a slow business if the trout are searee. The drop-minnow is perhaps the best thing of all for brook fishing if you can get the baits. I prefer the old-fashioned hook for it in such waters, a No. 6 or No. 7 with a leaded shank. You can make an efficient hook yourself casily with a little lead wire. The hook link is threaded through the minnow from mouth to tail, the lead lies in the gullet, and the hook point projects from the mouth. You can strike with this hook quite as quickly as you do with a worm, and there is no great danger of a small fish gorging the bait. For more open waters, however, I rather prefer a drop-minnow 
tackle which has a triangle somewhere outside the bait; there are several good patterns on the market.

Very different from these south-country streamlets are their cousins of the north and west, the threads of moisture that make their way down from the moors to join some rapid mountain stream. It is marvellous how some of these burns manage to support a head of trout at all. When they are dry they are very, very dry; what little watcr remains in the depressions, which by courtesy one ealls pools, scems almost too stale, as well as too shallow, to keep anything with gills alive; one realises the value of water weeds by sceing what happens to a little burn, where there are none, after a drought. Weeds must be almost as important to oxygenate water as movement and exposure to the air. But these burns have no weeds, and they get very stale, indeed, so stale that I think their trout must forsake them and wander away into the heather. At any rate, if you follow the stream up in low water I will defy you to see anything over the status of a fingerling, a little-fingerling, if I may so put it.

But when the hills have been lost in grey wool for half a day, when the thunder has crashed about the roeks, and the good rain has poured as if it knew its duty, then the trout all come back again 
out of the heather and lic at every corner, behind every stone, assimilating worms as fast as jaws can work and stomachs digest. Set out while the water is still porter-coloured-and you will scldom find it more definitcly tinged at these altitudes, where there are no road-washings-and ply your wormtackle, and you will find that the neighbouring heather must have becn alive with fish, some of them brave fellows of five and six ounces. I do not remember ever getting a veritable halfpounder in one of these mountain burns, but I have had fish not far off that weight, and sometimes two or three in a day to help out the average.

Now and again I have had very pretty fly-fishing in one of these tiny streams, generally after two or three wet days, when there is a good volume of clear watcr coming down, but occasionally, too, when the effect of a spate has almost passed off. Once, I remember, when the Penydwddwr was in thick red flood, having come down upon us rather suddenly, I was caught unawares. It was much too thick for the fly, and I had neither minnows nor worms. Also, I had a very wet jacket and was generally feeling morose, especially as I knew that Caradoc and the rest of the party, who always go prepared, must be having inglorious but solid sport in the eddies lower downstream. So when I came to the Forsaken Burn, and the sun came 
out, I hung my coat to dry on a bush and meditated.

The Forsaken Burn, which comes out of the west, was an odd contrast to the turbid Penydwddwr, being at its lowest. It looked lifeless and its pools were in parts positively bescummed as a result of the dry weather. Evidently the storm had been very local, and the western hills had known nothing of it. By way of doing something while my coat dried in the sun and wind, I made a cast into the nearest pool, and, to my surprise, immediately rose a good trout, which gave a run, a jump, and was off. After that I fished carefully upstream for some little distance, and in each pool had a very similar experience. Altogether I must have spent an hour on the stream, and hooked quite a dozen trout of decent size. But I did not land one. It was a curious, though unsatisfying, adventure, and I returned to my coat in a worse temper than ever. But the day turned out not so badly after all. I put on the biggest and darkest flies I had, a zulu and a cochybonddu on No. 5 or No. 6 hooks, and started to fish my way homewards. And at once $I$ discovered that the Penydwddwr was not too thick, after all. The trout simply raced after the flies, and I made a good basket of twenty-two in a comparatively short time, besides losing a good many, which were, of course, the biggest. 


\section{SOME 'TINY WA'TERS}

But the Penydwddwr, though no Amazon, is too wide a water for this chapter, which should contain nothing across which a young man could not jump pretty often in each quarter of a mile. I should like to include in it some of the extraordinary little streams which I have seen in the New Forest, and which, I am told, contain trout. They are very curious trickles, and should provide some difficult and tangled fishing, but I have never been in the way of trying one. Worthy of separate classification, perhaps, are the mill-leats, which are often to be found beside the wet-fly streams of Devonshire, Wales, and other districts. Many anglers pass these places by with scorn. Nor will I seck to dissuade them, for there is not much room on a mill-leat for more than one rod, and there is no reason why it should be bruited abroad that the fish in it are better than those of the main river, brighter, fatter, and heavier in proportion to their length. Besides, it would be no use telling them that the mill-leat has a bright gravel bed and quite an abundance of food-producing weeds. They look at it, perhaps, and they see that what with its natural narrowness and the drooping grasses at each side, it offers no more than a foot of water on which to place a fly. So they say "Pooh !"

But what battles I have had with the quarterpounders and six-ouncers in that foot of water! 
What half-pounders, aye and better, have I not lost ! I live in hopes of some day really doing justice to the possibilities of a mill-leat, and getting at least a dozen fish out of it, averaging three to the pound. It certainly could be done with luck and a steady hand. That is, perhaps, the trouble. As one works the fly downstream-upstream fishing in so small a water, which is relatively deep, does not seem to rouse the fish so effectually-the trout come at it with a bang, and the hand involuntarily responds with violence, so that the fly is missing aftcrwards, or, at best, the trout is off after a flounce of surprise The fish should in such a place be allowed to hook themselves, the angler doing no more than hold the rod-point steady when they rise. But it is much easier to preach this doctrine than to practise it, and my progress down the leat has always been a story of catastrophe. Occasionally I have had three or four nice little trout, but what are they to the splendid creatures that I ought to have had?

Also to be ineluded in the category of jumpable streams are, I think, the top reaches of some of the chalk streams, and many of the carriers which feed the water-meadows all along their courses. But these are too important to be squeezed in at the end of a chapter, and I have spent so many happy days on them that I owe them a better compliment, which I hope presently to pay. 
Here, however, I may touch on a topie which to some extent concerns them, as it conecrns all the others, the question of a rod for small stream fly fishing. I have found, and, I think, others would find, that the possession of a really small rod adds immensely to the pleasure and interest, and, in many cases, to the comfort, of angling in tiny watcrs. I began to fish them with a weapon of about nine fect. Then I came down to cight feet six inches. Then, to cope with a Yorkshire beck which ran mostly under an avenue of bushes, I dropped to six feet six inches, getting a short handle made for the two upper joints of a small greenheart. Later, however, I discovered the rod mentioned before in this chapter, a baby split cane seven feet long, which Hardy Brothers had built to a pattern prescribed by that good French sportsman, Prince Pierre D'Arenberg, and which bears his name. I made myself a present of one of these and am now suited, as they say in domestic circles. The rod weighs something infinitesimal, and is small enough for practically all purposes, and yet it will cast a surprisingly long line if you need it, as you sometimes do on the smallest stream. Also, it will handle a fish with tact, a point on which I shall have something to say later, but also, if required, with firmness. At this, I suppose, one ought not to be surprised, if Dr. Mottram's theory, set out in his interesting 
38

\section{TROUT FISHING}

book, Fly Fishing: Nerw Arts and Mysteries, is correct; viz., that the shorter the rod the more strain you put on the fish. All the same. I am always surprised when a small rod puts up a valiant fight. 


\section{CHAPTER III}

\section{A LITTLE CHALK STREAM}

IT would be hopeless to attempt a celebration of all the carriers and drains which have given me hours of delight on the Itchen, Test, or Kennet, though they come under the category of little streams. Each several one would tempt me on to a lingering description of its features. There are carriers whose every yard almost has some special significance to me, as the scenc of the capture, or loss, or sight of some particular fish. It may be noted that a fish which one has only seen may live quite as long in memory as a fish which has actually been caught.

I could, too, dwell lovingly on memories of the small upper reaches of one or two of the lesser chalk streams, such as the fascinating Gloucestershire Coln round about Ablington, the Lambourn near Boxford, Driffeld Beck above Sunderlandwick, or the Dun at Hungerford. They all have delightful characteristics and each would require a volume to do it justice. The art of catching trout in a chalk stream which runs very shallow over a relatively wide bed-the upper Coln and the Dun 
are of this character-might in itself be expounded in a treatise of many pages, though I should not be competent to write it.

Instead of attempting to set down the catalogue of days which I have at one time or another enjoyed on these small waters, I will give some impressions of a season on a little river which has been less described in print than most of our southern streams of any note, though it should perhaps have received frequent celebration, beeause it was the stream by which Izaak Walton must have spent many days during the later part of his life. This stream is the Meon, and anglers who are curious to trace Walton's association with it should study the chapter on "Izaak Walton at Droxford," in Canon Vaughan's delightful book The Wild Flowers of Selborne. It gives some information as to the old man's Hampshire life and friends which I have not found elsewhere.

The Meon must have been a trout stream after his own heart, if it had the same eharacter in his day that it has now. In the part which I know, at any rate, it may be described as a chalk stream in miniature. Lower down it may be more considerable, but I do not know the reaches near the sea. Near Droxford, which was Walton's abode, it is like the Test writ very small, with all its features clear but tiny. There are intoxicated little ripples, 

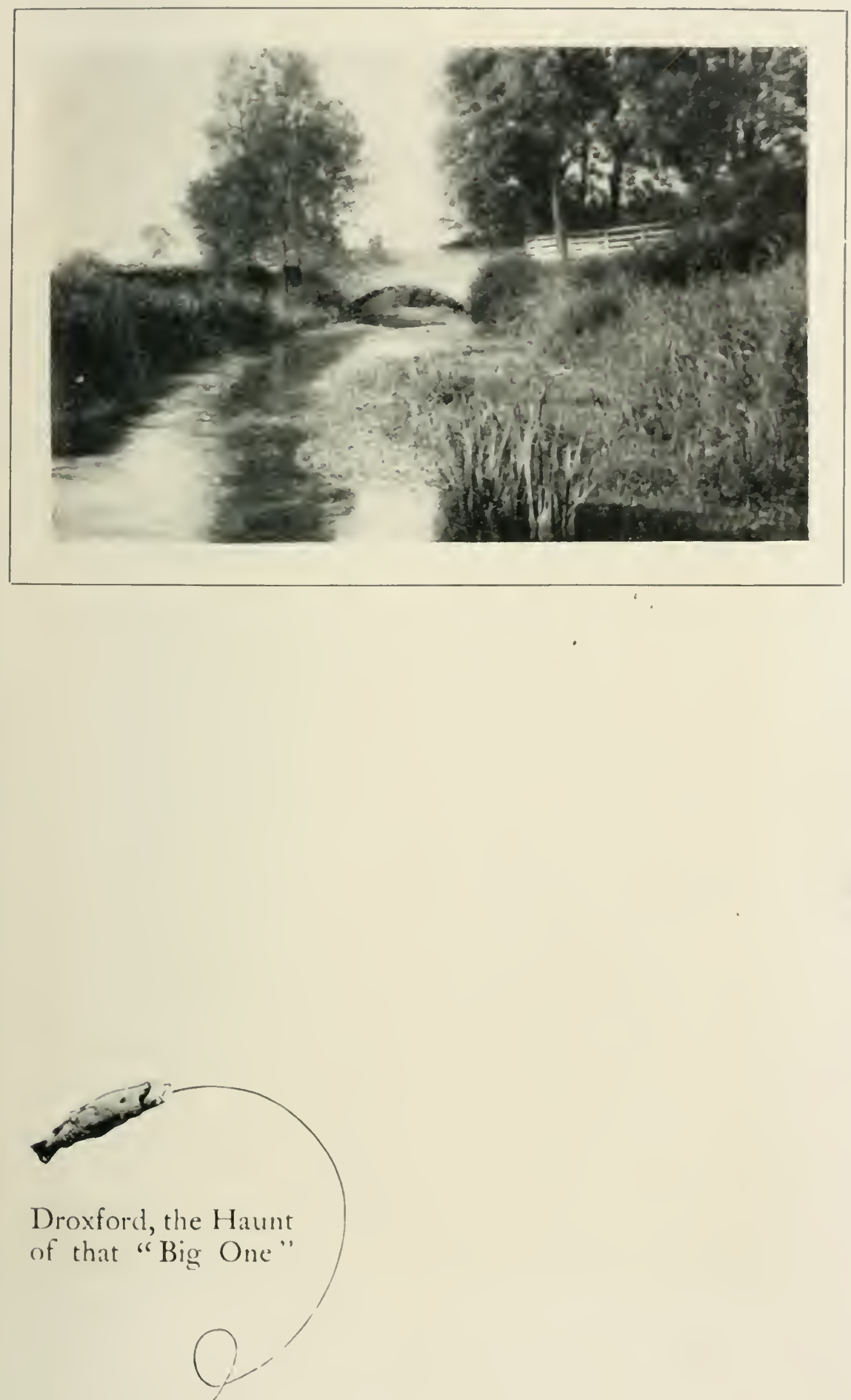



\section{A LITTLE CHALK STREAM}

sober little pools, contrary little eddies, turbulent little hatch-holes, and all the rest of the scencry complete. The weed-beds are circumscribed but vigorous, the accumulations of mud insignificant yet definite, and in places the banks quake like their betters, while a man may subside into little quagmires just as he would in more important places. Happily he does not subside very far, so he gets a sense of adventure without undue risk or discomfort.

As the river so the trout. They also are built on a small, though perfect, scale. Their average weight is about ten ounces-by that I mean the average weight of trout killed on the fishing which I have specially in mind. In some parts of the stream the average may be a little lower than this, half a pound perhaps. Nowhere, probably, is it very much higher. A pounder is looked upon as an achievement, and the biggest caught by any rod on the water in question during two scasons did not exceed a pound and a quarter. For a chalk stream such weights are small, and there are mountain streams which could show almost as good an average in parts of their course, which certainly yield bigger fish occasionally. The Usk in Wales and the Deveron or Don in Scotland would possibly not suffer by comparison with this Hampshire stream.

Size, however, is not the only eriterion of merit, 
and smaller trout often have qualities denied to big ones. That is certainly the case with these. If the two-pounders of the Test behaved with their impetuous vigour on feeling the hook, the diaries of Test fishermen would show much less imposing totals. It is on the whole fortunate that big fish in weedy waters are not given to acrobatics; otherwise they would seldom be landed with the little hooks and fine gut that dry-fly fishing makes necessary. It is not the trout that runs far and fast that is dangerous to the tackle, nor is the trout that dives into a weed-bed and stays there necessarily a lost fish; a gentle coaxing with the hand on the line itself will in most cases persuade him to come out again.

The really awkward opponent is the trout which goes off at a burst for six or seven yards, turns sharp to the left going slap through a patch of weed, takes another burst straight upstream, turns to the right into more weeds, dashes out on the other side, and finally comes to anchor, having, for greater sccurity, taken two turns with the gut round a convenient rush. This-with certain modifications according to circumstances - is the customary procedure of the trout here. They are greatly helped by the nature of the stream, since they need never travel far to find some device for giving the angler pain. It follows therefore that their capture, when 
they are hooked, is anything but a certainty, which adds of course enormously to the interest of the game. It may be said, in fact, that these small fish are just as hard to land as their heavier brethren in bigger streams, and this is equivalent to a statement that they are entitled to just as much respect.

If a man wants to make the most of the small fish in streams like this (for it is by no means the only one in the chalk system) he can modify his tackle, or, at any rate, his rod. A miniature rod, such as I have before deseribed, scems designed specially to match those miniature rivers, and its use certainly makes the fishing seem more important. I began the season with a bigger rod, but one day took down the little one in order to fish in a backwater which is so overhung with trees and so beset with bushes that a longer rod would not avail there. I found the toy to answer so well and to handle the fish so cunningly that I afterwards took it to the more open water, and for the rest of the season used nothing else there. These tiny rods rather tend to get you hung-up behind if you attempt a long line, so they necessitate an extra amount of crecping and crawling in the approach of rising fish. As the dry-fly man ought to creep and crawl-it is part of the fun-that does not matter. A certain advantage is to be found in the delicacy with which such a rod responds 
to the movements of the fish; it may stop him from doing some of the more outrageous things that he has in his head, by making him think that his less elaborate devices are succeeding-till he finds, too late, that he has wasted his time and strength on futilities.

Expert dry-fly men generally counsel the novice to " bustle" his fish, to be as hard on him as the tackle will allow, and to get him to the net as quickly as possible. This is sound enough for some occasions but not for all. Sometimes a trout may be hooked in a place where his escape is an absolute certainty if he chooses to put out his strength and exercise his speed. A little, clear pool with trec-roots or trailing brambles at its sides is such a place. Unless the angler's tackle is strong enough for a sheer pulling match, as it seldom is, his only chance is to play the trout as though the cast was made of cobveb, to yield to his every movement and humour his every whim. It is surprising how often and how quickly that treatment will bring the fish peacefully, and without fuss, to the net. With a small, light rod it is much easier to play a fish in this way than with a long, heavy one. The susceptibility of trout to gentle treatment shows that this violent behaviour is due as much to shock and sudden alarm as to the fact that they have been hooked. If you have struck quietly and kept the lightest strain on after- 
wards, the fish secms to be hardly aware of anything wrong. If, however, you have struck hard and begun to pull hard, he becomes a violent opponent at once.

In one important feature our little chalk stream differs from some of its pecrs-the difference is possibly more noticeable on this part of it than on others-and that is in the matter of fly, and the consequent rising of the fish. I should hardly like to say that fly was less plentiful, but it is certainly less concentrated. The time of the rise is not nearly so well defined as on the Itchen, for instance, and it is not often that you could lay your hand on your heart and say, "Why, every trout in the stream is on the feed." On the other hand, it is not often that you could say with gloomy ccrtainty, "Not a blessed trout is moving anywhere." For nearly always there is something moving, or willing to move, somewhere, and you can get rises at any time of day if you are persistent and alcrt. You can catch fish, moreover, by speculative casting in likely places, a method which is of doubtful value on the Itchen in most parts that I know.

This freer habit of the trout is wholly commendable to busy men whose fishing days are few, for it means that less hours are absorbed in mere contemplation. The catch may not be more numerous in the endan Itchen rise is often a busy and crowded time-but 
it will have been more evenly distributed over the day, and that counts in the balance of enjoyment.

Why, it may be asked, is there such a difference in the habits of trout in two rivers not many miles apart? Several explanations may be given with some confidence. One is that the little river is rather shallow and rapid, a character which makes for greater alertness in its inhabitants. Another is the fact that its trout are smaller. Half-pounders are everywhere easier to rouse than fish of twice or three times their weight. But most important, I think, is the character of the food-supply. This little stream is certainly richer in "oddments" than a bigger one would be, or at any rate the oddments make a braver show and stimulate more fish. Plenty of beetles, catcrpillars, crane flies, ants, and other irregular fare must reach the trout of a big river, but only as a rule those trout which lic close to the banks. In a narrow stream such as this, however, the fish which lie in the middle expect a share in the good things too, and no doubt get it. So the proportion of what may be called casual feeders is greater than in the bigger rivers, and the angler's chances are accordingly more numerous.

Where all is delightful it is hard to declare a preference for one bit of the stream over another. Looking back on that past season I get a series of precious memories, from the first day when I hurried 


\section{A LI'TILE CHALK S'TREAM}

down the great field which slopes from the ehurch to the ford (on a very hot day you can bear to the right and have the grateful shade of an avenue of elms for most of the distance), to the last day in September when I hastened uphill along the road from the top of the water, not without misgivings as to the time left for eatehing the last train.

Near the ford, which is practically at the middle of the water, is the choicest spot for luncheon that Nature ever devised. Five big trees, chestnut, elm, ash, oak, and beceh, there combine to ward off the sun, and then the stream, always in the shade, babbles round three sharp corner's with the impctuous fuss of a mountain brook. With a brace in the creel, or without it, an angler could never fail in that spot of a divine content. Hard-boiled eggs, a crisp lettuce, bread and butter, and a bottle of amber ale a-cool in the water at his feet-what could appetite want better in so "smiling a corner of the world"?

And (let me but whisper it) if by lunch time the ereel is quite empty, and if a fish or two are urgently required for some kindly purpose, and if last night the evening lise was all sound, sight and fury, signifying nothing, and if-but the fisherman knows these if's well enough to dispense with the list. Granting the if's, there is the stream rippling along under the boughs and over the gravel, as it had 
been in Devonshire. What more natural than to respond to so obvious an invitation, and to see what a blue upright or Greenwell's Glory may achieve fished wet downstream? A wrong proceeding, I grant you, yet not without the palliation of difficulty, for the rod must be kept low and the line switehed cunningly to avoid the overhanging boughs. And the fly must hang seductively in the eddy behind the ash roots, must move convineingly across the stream, and must be made to tarry here, to hasten there. There is more in the wet-fly business than contemptuous prohibitions would secm to allow, especially in a place like this. And when the tug comes, and a fierce fish is gone away downstream and round the corner, the angler is prepared, puffing and splashing after, to vow that never did trout hooked on orthodox dry fly make so fast a run or pull so hard. It is surely the not impossible two-pounder at last.

It is well that two anglers should be on the fishery together, because there is then no difficulty as to which part of the water it were best to visit. For two rods there is an obvious division into an upper beat and a lower. Alone, I sometimes knew fearful indecisions, and if, after much turning of the swift mind this way and that, I went upstream, there would presently come a craving for the lower water. If my feet carried me to the bottom hatch where the 
boundary is, my heart would surely fly to the bridge right at the top where, close against the brickwork, would be rising that big one which I could always move and never catch. Positively to get full advantage of a very varied bit of fishing a man needs to be "two gentlemen rolled into one," but capable of unrolling at need.

If from the luncheon corner one goes up, one comes to the water which is perhaps most typical of a dry-fly stream, and the higher one goes the more tempting does it become. There are two little weirs, three bridges, and several stretehes with a steady and smooth current where rises and flies can be easily seen. $\mathbf{A}$ good deal of the lower water is too swift and broken for comfort of vision, and frequently one has to guess at the exact position of one's fly. Even keen-sighted and experieneed anglers probably have to do this more often than the beginner suspeets, but they are never quite happy about it. It leads sometimes to distressing incidents. I shall never forget a vast 'Test trout which on a very windy day took my fly four several times. My eyes on cach occasion were carnestly fixed on a natural fly which floated hard by the artificial, and on cach occasion I found out the mistake just too late. A brisk ripple on the water made spotting the right fly a matter of sheer luck. 
There are several very difficult bits on this upper water. In two or three places a willow leans across the stream, and under each is a deep hole with an eddy behind the trunk. Practically the trout in these strongholds are not to be caught. Occasionally one may be hooked by the arduous process of dibbling through the network of twigs, or by casting a very short line just over the tree trunk upstream. But an immediate retreat to the shelter of the roots very soon frees that trout, and probably teaches his fellows wisdom; at any rate it is quite a rare thing even to get a fish on in these places.

Another difficult place is a delightful glide under some bushes on the far bank. The bed of the stream shelves gently here so that the water is only an inch or two in depth on this side and perhaps two or three feet on the other. For some reason connected with the light it seems almost impossible to get a fly to any rising fish in this piece without alarming him. No matter whether you crawl close to the edge or grovel out in the meadow, something-your head, your arm, the flash of the rod, or the curving lineis perceived by the trout, and he withdraws as quickly as may be. None the less the angler will certainly waste a lot of time here, because the place is so tempting to his eye.

For the sake of the basket it were wiser to go on a few hundred yards to a part of the stream which 
is somewhat deeper and formed into a suceession of little runs and pools by beds of weeds. Here the trout are not easily scared, and when the fly is hatching they rise very frecly, half a dozen or so in cach pool and two or three in cach run. At the first sight the angler says to himself " $\mathrm{Ha}$ ! they are delivered into my hand," and probably forms a resolution not to take too many. Sueh a simple and confiding folk deserves chivalrous treatment. But when he has been pegging away for half an hour or so with no result but a few short and splashy rises his mind is altered. He desires, and desires very badly, to knock one or two of these fish on the head. The trouble here is the drag. Owing to the irregular growth of weeds the current varies in pace with every few inches, and the result is that the fly is made to do all sorts of unnatural things. The drag can be overcome by very careful use of slack-linc but only after much study and expcriment. Onc learns to regard a brace of fish caught in this reach as a solid and satisfactory hour's work.

It is not so very far from this point to the road bridge, which may be called the top of the water. Having attained to this the angler commonly begins to think of tea, and of the little low-browed inn which may be reached in five minutes, or perhaps a little more, since the road winds uphill, and waders and brogues make slow going. First, though, he 
must spread his elbows comfortably on the parapet and gaze into the deep pool below. Let me here tell the story of the great fish. It was " no fisher but a well-wisher to the game" (in Sir Walter Scott's phrase) who discovered the great fish, and who made, so to say, no small song about it, for it was creditable in a well-wisher to have detected a monster which the fishers had completely overlooked. So long it was (hands two feet apart), and it lay just to the right of the strongest stream, in the very deepest part of the pool. The fishers, much perturbed, at once set out to test the matter, for a two-foot trout is a six-pounder at the least. Sure enough there in the spot mentioned was a shape, broad and dark and obscure by reason of what Blackmore might have called the "nebules" in the water. "Golly" and "Great Scott," said the fishers, and they went away.

But at dusk for several evenings a stealthy form would approach the pool from below, there would be a swishing in the air, and presently a sort of plop, as a sedge suitable to six-pounders hurtled on to the surface of the water. Nothing came of it, but every morning there was the dark form in its accustomed place to inspire new stratagems and provoke fresh efforts. Then at last came a morning of bright sun and unusually low water-a mill above was perhaps holding the stream up for an hour or two. 
And the murder (it might almost be called that) was out. A child's toy boat lay waterlogged and derelict on the river bed. Its lines were not at all unlike those of broad-backed trout, and a straggle of weed made a very passable tail. It was immediately evident that precious evenings had been wasted and there was a sudden transference of affection from the upper to the lower water, where men were not mocked by simulacra.

For beauty the lower water could not compare with the upper, being almost destitute of trees, and open to sun and wind. But for interest it might be held superior. The main stream is somewhat swifter, rather deeper, a little narrower. Its fish are, maybe, an ounce or two heavier as a rule and perhaps rather better fed. One remarkable trout, caught almost at the boundary, weighed a pound though it was only twelve inches long, an exceptionally deep, fat fish.

To me, however, the interest of the lower water lay not only in the main stream. Here the meadows are kept pretty constantly irrigated, "under water" as it is somewhat largely termed, and the result is that there are many carriers and side strcams criscrossed about. In most of these you may find trout, often, too, bigger trout than are commonly caught in the river itself. The older fish of all ehalk streams secm to have a tendeney to wander into the irriga- 
tion channels where no doubt they get very good feeding of minnows, slugs, beetles, and other sustaining things. To me there is something very fascinating about these outliers, and fishing the carriers is a joy. These carriers are the more amusing because they are so tiny. Getting a threequarter-pound trout out of a runnel two feet wide and eighteen inches deep is the queerest adventure. It is not orthodox fishing as a rule, for the fish seldom rise-there is no hatch of fly to speak of. But deft casting in the likely spots will often fetch up a fish whose existence was only hypothetical.

One day in one of these carriers I saw what looked like a dimple under a dockleaf. I put a ginger quill on the place, had an immediate rise, and then for about five minutes walked solemnly up and down in attendance on the biggest trout I ever hooked on the fishery. He never hurried himself, but cruised to and fro, and in the end the fly came away just as I was wondering whether it would be a matter for the taxidermist. I think that trout was a twopounder, though, of course, estimates of lost fish are suspect by general consent, and it does not do to be rash. Anyhow, I can say without hesitation that I was filled with grief that bordered on despair.

One of the two biggest fish I caught during the scason was the result of long-continued efforts on 
what is known as the backwater-in reality a little side stream which joins the river near the ford. Near the point of junction it is quite considerable, though almost without current. Herc big trees shade it from the sun nearly all day, tall rushes grow along the bank, and the trout cruise about in droves lazily sucking in gnats, spinners and other trifles, and occasionally splashing at the sedges which are tempted out by the subdued light. There are a couple of hundred yards of this still water, and one can casily spend a morning here pecping through the rushes and occasionally dropping a fly in front of a fish which comes within reach-they patrol the place like peaceful pickets. On a very hot day this waiting game is to be commended, and a brace of trout may be caught without too much hard labour.

Ordinarily the fish are no bigger than those elsewhere in the fishery, but one day I became aware of a mighty one which smacked great jaws as he fed, and made great commotions as he moved about. Presently I saw him, and he had fiftecn or sixteen inches to his credit. And then I rose him and hooked him; the water heaved as he rolled over, and the fly came away. For several week-ends I pursucd that fish in vain. He was sometimes in one place, sometimes in another. Occasionally he would make a pretence of rising, but he would 
never really take a fly again till a day nearly at the end of July, when I overcame his caution by a trick which was probably very wrong. I put on a fly with a long straggling hackle and placed it before him. He came, looked, mocked, and went away. I withdrew the fly and waited for some minutes till he returned on his beat. Then I cast it in front of him and as he came to look again twitched the point of the rod ever so slightly. The fly waggled on the water, the fish perceived that there was something which had life and movement, opened his jaws wide, closed them-and in duc course weighed one pound three ounces. Without prejudice, he should have weighed a pound and a half, for he was not in good condition.

Higher up, the backwater gets smaller and smaller till at last it has no obvious existence at all. Its course is absolutely choked with coarse rushes and other vegetation, and most of the little pools are screened with impenetrable bushes and protected by drooping boughs. Yet in some of the clear spots there are trout, and good ones. I used occasionally to get one here and there at the expense of scratches from thorns, stings from nettles, an aching back, and very undignified attitudes.

It was not bad fun but it was laborious, so one day early in June I decided to make the place fishable, and put in some perspiring hours with a 


\section{A LITTLE CHALK STREAM}

billhook, a saw, and an iron rake. By tea time there was a real improvement visible, and for nearly half a mile the stream was approachable at regular intervals. Alas, for human aspirations! A month later when I inspected the water, things were worse than ever. I could not get a fly on to it anywhere. The nettles, rushes, bushes, and trees had acquired so mighty an impetus from my pruning that they had combined to choke the little stream altogether. Perhaps it was not the pruning, but the power of growth which is natural in the valley of a chalk stream.

I do not resent my defeat by incensed Nature. The experience in retrospect is even pleasant, for it blends with the other impressions given by a scason on a Hampshire river, all of them testifying to the wonder and beauty of life. 'Nowhere in England could one get impressions more varied or more vivid. The plovers which made a routine business of trying to persuade one to leave the lower meadow, where they had family affairs; the little company of stoats which one day played like kittens round a broken hatch-board; the tiny dabchick which had just left its shell, and scemed in danger of drowning till a landing-net rescued it, and helped it to a patch of weeds; the fricndly carthorses and placid cows - all these things combine with the flowers, bees, butterflies, and 
other lesser creatures to make up a rich feast for memory.

Fair sights, sweet sounds, the scent of may or meadowsweet, and a clear river rippling in golden sunshine-has life anything better to give? 


\section{CHAPTER IV}

\section{THE FISHING DAY}

Noт long ago I got into a smoking-carriage and found already seated therein, with his rod and bag above him, a distinguished fisher who considers himself one of the veterans of the angling world. He often insists, to the surprise and protest of his friends, that he was, so to say, in his young prime during the consulate of Plancus. And we have to admit that he seems to have a personal knowledge of what a Berkshire keeper of my, and a good many other people's, aequaintance delightfully calls "times been gone by," which argues not a few decades beneath the sun. "I should be afraid to say," obscrved my friend, "how many years I have been coming up and down now. And do you know"-here his face took on a slightly ashamed, yet happy, expression-"every time I get into this train I enjoy it more. I fecl like a schoolboy just off for the holidays." As my friend steps into that train at most weck-cnds during the trout season it is obvious that his sensations have not lost their keenness by being often repeated. Nor was there 
any less fire in the narrative which soon followed of last week-end's " pretty two-pounder" than there has ever been in his tales of triumph, or any less enthusiasm in the description of the birds that were noted during the visit. To feel once a week like a schoolboy going home for the holidays is a wonderful aid to the preservation of enthusiasms.

And of course my friend is not alone in that. He is, indeed, one of a great company. All trout fishers, who are really fishers by nature and not merely because sporting fashion prescribes a few days with the rod as an essential to the complete sportsman, must know the intense joy of being on the way to their fishing with all its excitements and thrills in prospect. For the time being they are detached from the rest of life with its worries and troubles, and every one they meet, everything they see, the whole tangible and visible world is more or less in keeping with the peaceful and blameless nature of their errand. I often think it can hardly be possible that the inhabitants of certain delightful fishing resorts are quite perfect. There must be some little flaw in them somewhere, because they are human beings. But on a fine fresh May morning as one takes one's way to the river the streets certainly seem to be peopled entirely by the pick of humanity. Even the small boys proceeding schoolwards with shining faces would appear to be decorated with 


\section{THE FISHING DAY}

halos. That in itsclf easts a serious doubt on the value of one's conclusions, because as a matter of fact small boys are never, or very seldom, decorated with halos. Still it is none the less pleasant so to picture them for a few blissful minutes.

The trout fisher's day should by all means begin at seven, or not later than a quarter past, and I hope I offend no prejudiees by suggesting that a eup of tea and a slice of eountry bread and butter should greet the awakening. The boots should say "Nice drop of rain last night, sir," when he brings them in and at the same moment a gleam of sunshine should make its way into the room to show that there is no fear of the rain spoiling the day. The morning tea after rain and in the sunlight inspires the happiest imaginings as to what will come about. Many is the noble brace of trout (or round dozen of trout; it depends on the locality) that I have eaptured soon after seven in that blessed half-hour of prognostication.

Breakfast should be at eight, and the only communications that have come by post should be personal and of an eneouraging nature. "I do hope you will have good weather, and I should eertainly stay till Wednesday if . .." That is the kind of tone needed to start the day. It confirms you in your opinion that you are doing the eminently right and proper thing in taking a holiday. The 
sort of letter which has a business complexion and speaks of its writer's being "greatly disappointed at missing you to-day" and hopes "that you will be able to find it convenient" to make an appointment within the next two days - that sort of letter ought to be lost in the post. It casts a gloom over everything, makes you suspicious of its writer, and gives you the bother of composing and sending a non possumus telegram. It may even delay your starting for five minutes. Of the letter which causes you to return to town by the next train I will not speak. I hate that letter too much.

The only excuse for not being on the water by nine is a visit to the local tackle shop if there is one. Ten minutes there spent in selecting flies and casts and hearing about fishing things in general are by no means wasted. They serve to whet the appetite, already keen, for the day that is coming, especially if you receive full and particular intelligence of ecrtain big fish which have frustrated all local efforts. About 9 a.m. on the first morning you naturally have your own opinion as to local efforts. They are perhaps the only local things that have not that quality of perfection already noted, which but makes them the better from your point of view and fits them the more happily into the general scheme of joyousness.

In due course the water is reached and with the 
first glint of it comes perhaps the finest sensation of the day. Some men save a morsel of time at this moment by being quite ready, the line being threaded through the rings and the cast with the fly or flies attached to it. I do not blame them at all. Time was when I would have gone even farther and extended line as I crossed the meadow so as to hasten events by a few seconds. But now I think I prefer the slight check that comes by not having made the final arrangements. Very occasionally it happens that I become aware that the rise has begun the moment I get to the water, and then there is a delightful feeling of running a race with time. Perhaps, one feels, one of these early morning rises of which one has heard may have happened and this may be the tail-end of it. But at the same time the alarm is not too acute. There is underneath a comforting conviction of the probability of being busy for a good many hours.

Of course if you are late on the water it is different. Once I remember getting to the Itchen about noon and finding the rise well on. I caught the first three trout that I covered all in a few minutes, and then every movement ceased. There was nothing more to be done all day till the evening rise began. On another less prosperous oecasion I got to the Kennet at Hungerford in what should have been good time, about ten o'clock, to see what I verily 
believe was the last Mayfly honestly taken by a trout that day. Between nine and ten there had been a splendid show of rising fish, probably the best of the season, and the only angler out so early had made a fine basket.

It is curious how little definite information there is among dry-fly men as to what goes on on their rivers before the dignified hours at which they think proper to begin their fishing. Nine o'clock may be considered the earliest imaginable time for them to reach the water, ten or half-past being much more usual. Of course they have been led to this not by dignity alone. It depends somewhat on the time of year, but as a general rule they do not expect to find fish rising much before ten. What I should much like to know myself is what happens in the early hours of a hot July or August day, or rather not of $a$ day but of the day, for isolated occurrences are not much of a guide. Are there at all commonly a hatch of fly and rise of fish before, say, eight o'clock? It so happens that for two summers I frequently had to cross the Kennet a few minutes before eight in order to catch a morning train. And on likely mornings I always saw a fish or two rising as I hurried past-the nature of things forbade a leisurely inspection, because these early trains take such a lot of catching. I had a strong wish to reach the spot about 5 a.m. some fine morning 
and to study what happened between then and eight. My suspicion is that what I saw at the later hour was but the end of important doings, well worthy of the dry-fly man's consideration.

But here even more is the nature of things a hindrance to action. Besides, I suppose it might be open to question whether a dry-fly man would consider himself, and still less another fellow, a dry-fly man at 5 a.m. Anyhow, the fact remains that I do not remember ever fishing on a chalk stream much before nine. Nor do I know more than one stream on which an effort has been made to solve the problem. Some of my friends have returned thence to breakfast carrying rods, but they have uniformly given short answers, which I hesitate to accept as evidence one way or the other. I think the weather has mostly been unpleasant when I have seen them so returning, and, anyhow, that stream is hardly typical, being subject to the vagaries of a mill and apt to hold very little water early in the morning.

The wet-fly morning by common consent may begin soon after daybreak, but here again I have little or no expericnee. I know that in hot weather and with low water there is a fertile period which ends just as I begin. Often enough have I had a brisk little bit of sport for half an hour or so, which has ceased abruptly as the sun has got on to the 
water. But somehow I have never, at any rate for many years, risen much earlier on account of this knowledge. And most of my wet-fly fishing has been done in the early part of the season when trout are more reasonable in their feeding hours. Nine o'clock seems to me a good Christian hour at which to begin, with the wet fly or the dry. And when, as sometimes happens, having begun at nine, you are still waiting for encouragement to continue at one, you begin to doubt whether on the morrow you need be quite so early. The morrow comes and you are there by ten, to find that, as in the instance I have recorded, the fun to-day really did begin at nine and is now just over. Fishing is an uncertain business.

Time was when I held firmly to the belief that the important part of the trout fishing day (setting aside those possible hours in the company of the lark, as to which I have confessed that I know little or nothing) was the morning. The period from ten till one was, I long considered, worth all the rest of the day put together, with the exception of perhaps an hour at the end of it. And if it came to be lunch time with my creel still empty I had all the feelings of depression which may be summed in the words, "Well, here's another good day wasted." And, for that matter, I still cannot rid myself quite of the old notion, and I still feel pretty desperate if there 
are no trout to be admired or counted during the luncheon interval; while, as for starting out in the aftermoon and getting to the water at two or thereabouts, I cannot rid myself of the old notion that it is bound to be a complete failure.

Yet I have had plenty of proof that the trout fishing day is by no means necessarily over at one o'clock. Often and often have I eaten luncheon in gloom and fared rejoicing to tea. I remember a lovely July day on Driffield Beck some years ago when I sat almost desperate beside one of the little weirs which give charming variety to the water above Sunderlandwick. My desperation was not so much due to the fact that trout had not been rising as to the fact that they had, and that I had been extremely unskilful or, at best, horribly unlucky. Fish after fish had been hooked and lost, and the climax had been reached by the loss of a real beauty in that very weirpool. I may have had one sizeable trout in the creel-I think I had-but that was as nothing in comparison with those which were not in it and ought to have been if I had had my rights. So I ate my sandwiches and cake for no more satisfactory reason than that one has to keep exhausted nature going. How different is such a repast from that seasoncd by the honest hunger which comes of carrying a fairly heavy basket! 
And then, after I had thrown away the last fragment of cake from a sensation of pure boredom at having to eat it, the whole complexion of the day changed. The trout which had been so hard to catch before suddenly became easy. They took hold of the ginger quill with determination and were all duly played to the net. I shall never forget that afternoon, the glorious warmth of it, the myriad hum of insects, and the fat golden trout rising so confidingly in the clear spaces between the weeds. It was one of the days on which $I$ have occasionally had to pause and exclaim gratefully to smiling Nature, "How I am enjoying myself!" I remember spending a long time over one really big fish, probably a three-pounder, which was rising, to all appearance recklessly, in a deep swirly place below a thick bunch of weeds and above a clump of rushes. Five or six times I got that fish up to various flies, but he never seemed actually to take one. At any rate I never felt him. Probably the swirly nature of his feeding-ground made the fly drag a little every time, enough to make him suspicious, though not cnough to be perceptible to me. It was some consolation, however, to be sure that if I had hooked him he would almost certainly have broken me in the weeds or rushes.

And even though I failed with him I had done very well by the time I turned downstream with an 
eye to tea at the keeper's cottage. I had killed two and a half brace since lunch and they averaged very nearly a pound and a half, which was extra good for Driffield Beck at that time. The biggest was a fat specimen of one pound fifteen ounces, as high a weight as Driffield ever gave me, during visits continued several years running. Though I believe there were monsters (and no doubt still are) in the lower part of the river, in the upper part two-pounders were not often caught. The weight of the fish, however, seemed to be going up by all accounts, so perhaps two-pounders are more plentiful now.

In the same year, by the way, I had another good day with the ginger quill, also getting most of my sport in the afternoon. That was on the famous shallows at Longparish on the Test. On that occasion too I had troubles, not in losing fish, but in finding a fly to suit them. When found the fly proved irresistible, and at last I began returning fish through sheer saticty. All the trout seemed to run about the same size, about one pound two ounces each, and I could find nothing bigger to fish for except two or three tailers which were unresponsive. My companion that day, the good R.B.M. so well known to angling fame, had an exactly similar experienec. With the exception of one fish I think our united eatch would not have varied more than an ounce or two, and it would have been hard to 
find a more level lot of trout. The exception was a rather ill-conditioned trout of a pound and a half caught, not on the shallow, but on the narrower water below.

The Longparish shallow is the place famous in history as the scene of Colonel Hawker's equestrian fishing. He used, we are told, to do his wading by proxy and catch great store of trout from his horse's back, fishing his wet flies presumably downstream. After a wet winter I have no doubt such a thing could still be done there with success. R. B. M. and $I$ were there after a wet winter, and the river held a lot of water. We were able to wade upstream abreast, and so wide is the Test there that we might have been fishing different streams. There would have been room for probably two more rods between us. It was a memorable däy, none the less because I believe we were the first anglers on the water that year.

More recently I had the privilege of another day there in company with "D. O'C.," whose initials are also well known to the brotherhood, and I was interested to renew my impressions of the place. It may have been imagination, but there seemed to be less water than at the earlier visit, and it did not look as though four rods abreast would be a possibility any longer. There had, on this occasion, been a dry winter, and of course it may have been that 
weed-cutting below had lowered the level of the river. Anyhow the place looked different. What also interested me very much was to find the fish a good deal bigger than they had been before. We saw plenty of two-pounders. It was a thundery, flyless day, and there was little to be done with them, but I got one nice fish of two pounds six ounces. This second visit was in July, a month later in the year than the first had been, and it may be that the big fish are later in taking up their quarters, which was one explanation given to me. I have noticed a similar thing elsewhere, but onc expects to find most chalk stream trout in their chosen haunts by June.

I had a curious afternoon experience on another very wide water, a portion of a beautiful Kennet fishery, not long before the war broke out. It was a bright day towards the end of June, the Mayfly was over, and the trout were as timid as hares, which they also resembled in their speed of departure. I was fishing from the bank, and was quite unable to get my fly to any fish without alarming him. In due course I reached the top of the water, where it is at its widest, decided that I was beaten, and started to come down again. And as I came down I became aware that some of the fish which I had frightened were back in their positions near the bank. At one, which looked a portly figure seen end on, I aimed my fly, drifting it downstream. 
The trout took it with the utmost confidence, and I got him out after a good fight, a two-pounder. And after that I hooked several more, landing three not quite so big as the first, and losing others. All were approached downstream by drifting, a method which has very seldom before given me any results worth mentioning. It was an eye-opener to me that such shy fish should be more approachable from above than from below. And I am afraid I must add that it was a pleasant surprise to me to find that I could catch a trout of any size by drifting. Previously I had had a sort of fatalistic conviction that I should be absolutely certain to pull the fly away out of the mouth of any large trout to which I might succeed in drifting it. I have since tried the plan again in that place with some success, so I hope I may have learnt something from the experience.

Though I have proved to myself that the afternoon is probably as good as the morning, and sometimes better, I much prefer a day on which the morning lives up to its good repute. I do not need many fish to make me happy. If on the chalk stream I have a brace by luneh time I am well content, and to have got into double figures by then seems good work in wet-fly fishing. Occasionally, though not often, it has happened to me that the morning has been too prosperous. Once I 

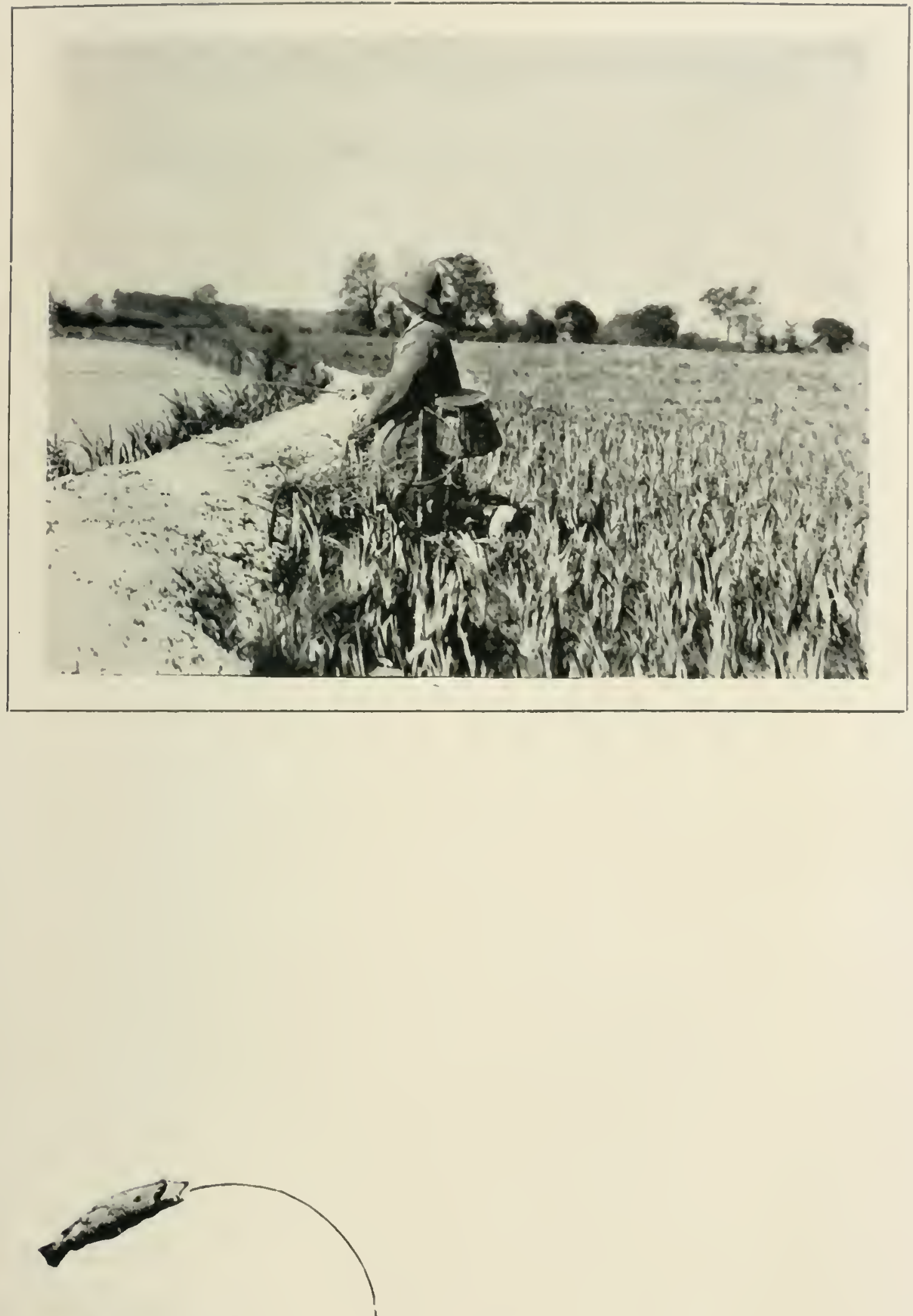

A Blazing Day on the Test 

fished a tieket-water where the limit was three brace of twelve-inch fish, where a pounder was considered a good one, and where a braee of pounders was esteemed good hunting. On that oceasion I found it a very good ticket-water indecd, the best ticket-water I had ever happened upon. Or perhaps it was (a thought which occurred to me in after-meditation) that I was a much better fisherman than I had imagined. For I could not help eatching the trout. They simply came and seized my fly and refused to get off. I returned a number, but even so my basket insisted on growing, and at two o'clock I found that all was over. The three brace were caught and killed (they averaged over one pound too), luncheon was eaten, and there was nothing for it but to go home. The real rise began at two, and the fish were then madly on the feed. I went home, thinking that in future I should be well advised not to devote a whole day to so casy a fishery. Fate, however, evens things up to us. Since that day the best basket I have been able to make on that water, doing all I knew, has been three. And I quite see that a brace of pounders there is good hunting.

That day gave me a nightmare. With its brisk sport and its anxiety as to not reaching the limit too soon, it set me on dreaming during the night. And I dreamed that I was fishing a stream belonging to a club of which I am proud to be a member, a 
club with very high ideals as to what is sporting. I fished and I had exceptionally good sport, even for a dream. And presently there came along the bank our honorary secretary, who is perhaps the best sportsman of us all. He asked if I had done anything. "Yes," I said, "I have done very well." And I showed him my creel, how it brimmed over. "And here"-I led him a little way along the bank to where a glistening heap of trout lay covered with fresh-cut sedges - " and here" - yet a few yards off was another similar heap. There must have been seventy or eighty large trout in all. But our secretary said no word. He simply looked sorrowful and turned away. And as he went I remembered for the first time that our limit on the water was at present two brace. I woke in a cold perspiration of horror at the thing which I had done.

Or perhaps it was not that day which gave me that nightmare, perhaps it was that other day on Caradoc's preserve when I had a great basket of five brace. "Five brace, my dear fellow, is our limit," he had said, so I seized opportunity by the forelock and slew them. And then when I reported progress with great pride, he looked grave at me. "But for our guests," he said, "the limit is four brace." However, I fear I never took that misdeed much to heart. These class distinctions are odious. 


\section{CHAPTER V}

THE E VEN IN G

The evening in fishing begins, to my mind, as nearly as possible at five o'clock. The interval between afternoon and evening is bridged by tea, that modest stimulant which is so refreshing to mind and body after a hot, tiring, and possibly unproductive day. Nearly all my friends laugh at my enthusiasm for tea, but I do not mind how much they laugh so long as they do not interfere with my plans for ensuring it. And I have converted a man here and there to my way of thinking, for which I do not always get thanked. There is nobody so desolate as the person accustomed to afternoon tea when for any reason that luxury is not obtainable. The angler who has grown to be accustomed to it would be well advised to take some trouble to get it. The provision of tea sometimes seems a new and rather revolutionary idea to dames who inhabit riverside cottages, but after coquetting with it awhile they usually come to see that it is not one of the impossibilities, and presently you will find that they take quite kindly to the business. Failing the 
convenient cottage or handy inn, there is of late years the new resource of the vacuum flask, so nobody now need despair of tea at the proper time.

To some stern souls this zeal for tea may seem contemptible, but I could advance many things in extenuation. Apart altogether from the question of food and drink, it seems to me no bad thing to put a definite line between the afternoon and the evening fishing. Thus you make your fishing day more important, and perhaps more interesting. Divided into parts the day has more variety, seems longer, and gives more opportunity for the feeding of that hope which is apt to be somewhat starved after the lapse of a few hours. The intervals for lunch and tea, if they do nothing else, afford opportunities for reflection, and reflection should calm the mind and stimulate the imagination. By the time the tobacco is lighted the angler is fit to fare forth and conquer, however many reverses he may have known during preceding hours.

I am inclined to think-nay, I am sure-that a further interval for dinner is also an excellent thing in circumstances where it is possible. It makes the day still more important, and it also makes a sort of midnight dinner unnecessary. In high summer you can go on fishing till ten o'clock, but it plays havoc with your conscience if you know all the time that there are unfortunate people waiting to give 
you a meal afterwards. Besides, it cannot be good for the digestion to dine at half-past ten and to go to bed almost immediately. A dinner interval about a quarter to scven by all means, and if that be not possible, take out what used to be called a " cold collation" and eat it on the bank. The idea of taking out supper never occurred to me till I read Mr. Raymond Hill's attractive book Wings and Hackle some years ago. Since, however, I have frequently acted on his advice and have had great gain from it.

For a good many years the evening has been more associated in my mind with dry-fly strcams than with others because most of my summer fishing has been done on them. A July evening should be divisible into several distinct periods, each of which has its special intcrest. First there is what I call the smutting time, which grects you as you come back from your tea. From five till perhaps six or a bit later in certain spots which you know well there will be the laziest possible dimpling of the surface by trout which have found something just worth eating, something invisible to you and not apparently very filling to the eye even of fish. Of all riscrs at any time of day or season these after-tea dimplers in July scem to me the most difficult. They will only condescend to notice the tiniest flies ticd to the finest gut, and if they do chance to rise at you you 
do not hook them, or but hook them to lose them at once. This period of the evening is supremely unproductive, and I have practically abandoned hope of doing anything with these fish. This in itself is almost fatal to success. "I shan't rise you and if I do I shall lose you "-when the angler thus addresses his prospective quarry he invites failure to be his companion.

There was once a huge trout in a hateh-hole. I knew him well but had never seen him rise, nor did I believe him capable of it. He seemed to me one of those established features which add dignity to a fishing without any risk of being upset. Most waters possess such fish, much as London possesses the Tower and St. Paul's. Your only lawful chance with them is with a red sedge at twilight, and if you do hook one of them then, it generally proves to be a smaller brother after all. Irish anglers, at any rate, will know what I mean. Well, one evening about half-past five I came to the head of the hatchhole, to find it low and placid; the customary stream was diverted into carriers, and the usual turmoil had quite ceased. I looked and was about to cross over and go on when I saw a dimple in the far corner downstream. This seemed worth investigating so I went round and peeped. There in but a few inches of water was the big trout, and he raised his nose as I watehed and took another trifle. In great 
alarm I put a fly to him, in greater I saw him open his mouth at it, and in greatest I wildly pulled it away just at the critical moment. Whereupon the fish sought the depths, making a great wave as he went. Nor did I ever sec him again. I verily believe I should have caught the fish and become famous in that district if it had not been between five and six. As it was, I knew I should not get him and didn't. I never catch one of any size during that barren hour, at any rate while the days are long. Why fish, then ? some one will ask. The fact that trout can be seen rising seems a sufficicnt answer; and, besides, there are always surprises in store even for the most unsuccessful.

The next period of the evening is one of absolute nothingness. No fly, no rises, no casting. This is the time in which the angler should have his dimmer, or collation, as the casc may be. From half-past six to half-past seven he ought to be otherwise quite unemployed. But he should be on the water again by half-past seven, for the fun may begin about then, though it may quite well be deferred till halfpast eight. The most glorious evening rise that ever' I had a share in-it was on the Test-began exactly at half-past seven, began badly for me, for I lost a beauty, the first that rose. Afterwards, however, I was kept busy till long past nine. It was an evening to dream about. The fish meant business and 
demanded nothing finicking in the way of flies, but were satisfied with a substantial orange quill on a No. 2 hook. After the first misadventure I think I landed every trout that took the fly except the very last, which got off in the dusk through being held too hard. I had four brace averaging over one and three-quarter pounds, and they fought so ficreely that playing and landing them literally occupied nearly the whole time; there were very short intervals between landing one and hooking the next. I do not suppose I shall ever have such an evening again. Very seldom indeed would it happen that the fish were in a taking mood for long enough to make such a basket a possibility.

As a rule, what fish are rising so carly as half-past seven are taking fallen spinner's, and they generally seem to me to be very hard to catch. Probably their shyness is due to the angle of the light at that time of day, and it is possible that some portions of a stream would be easier than others. Where shade falls earlier one's chanees are certainly better. There is room for a series of interesting experiments as to the behaviour of rising fish at different times of day in different parts of a stream. There must be a considerable variation in the perceptions of trout which at a given time are lying with their heads due north and of trout which at the same time are lying with their heads due west. And it 
may be that one's conviction of the difficulty of fish which are taking spinners is due to the geographical situation of the piece of water where one usually fishes. On another stretch one might find them easy.

After the fall of spinner comes the beginning of the evening rise proper when the blue-winged olives are hatching out. And here we are faced with what to me seems the greatest mystery that there is in dry-fly fishing. This is the extraordinary fact that on two evenings which scem exactly alike in point of weather, quantity of fly, rising of trout, and so on, the effect of fishing is so different. On the first you may rise and hook every fish to which you can place a fly properly. On the second you can do nothing at all, or almost nothing. In some cases the fish simply take no notice of any fly you offer them. In others you get an occasional false or short rise. In others the effect of floating a pattern of any kind over them is to put them down at once. Unless this curious contrast is also in some way due to the light, I have absolutely no theory to account for it. Nor did I ever meet any one who had.

Occasionally I have imagined that I have solved the problem by finding a particular fly which would do the trick on some such evening. I have, for instance, at times been disposcd to claim infallibility for Halford's blue-winged olives, for the orange 
quill which Mr. G. E. M. Skues introduced to me, and for the blue upright, which I was led first to try on chalk streams from previous experience with it as an evening fly on mountain streams.

Not very long ago another fly surprisingly added itself to the list of infallibles. It happened during an evening rise on the Kennet, when the bluewinged olive was hatching out well. For some reason the fall of spinner, which usually makes a certain number of trout rise, had not done so on this evening, only an occasional ring having appeared at long intervals. And for more than two hours the rod had been quite idle. About half-past eight, however, the duns began to hatch and soon afterwards the trout were taking notice of them. Obviously, according to my belief of the moment, the orange quill or the blue-winged olive would do what was required. But neither pattern gained the shadow of a rise. I changed to a blue upright. That failed. I tried a blue quill, an ordinary olive, a red quill, and several other approved patterns such as the coachman. They all failed.

I studied my fly-box gloomily and at last picked out a Greenwell's Glory. I felt no confidence in it at all for it was a pattern which I could not remember ever floating dry over a trout before; though, of course, it is a fly which many anglers use with confidence as a floating pattern, I had so far 
never felt the need of it. The specimen in question was a lightly-built affair intended for wet-fly work and not meant as a dry-fly at all. However, it could be made to float, nothing else seemed to be of any use, and the trial could do no harm. By now there was not a great deal of daylight left, and it seemed improbable that the position could be redeemed. But Greenwell's Glory did redeem it. Every fecding fish that was fairly covered took it well, and the result of about half an hour's fishing was five trout over one and a half pounds landed, and one hooked and lost. Obviously Greenwell's Glory must now be a permanent occupant of the fly-box, and one to be often tried.

Of course, as soon as it was promoted to being an infallible, Greenwell's Glory failed me just as badly as anything else. There seems to be no infallible fly, and, what is worse, no infallible selection of flies. I have been forced anew to the conclusion that there are evenings on which trout are not to be caught with anything. And the tragedy is that they look the best evenings of all.

After the hatch of bluc-winged olives is over there is the chance of picking up a fish or two with the sedge. Sometimes the chance is very good. Well do I remember one occasion when the great trout of the Test were, so to say, delivered into my hand. It was to be my record day. Despite great 
heat, I had during the earlier part of it caught four averaging over two and a half pounds (one being three and a quarter pounds), and during the evening I proposed to kill other two brace without lowering the average weight.

Things had not, however, prospered with me, for the blue-winged olive and other small patterns had failed, and I was reduced to the picking-up business with a red sedge in the waning light. And then the fish suddenly began to take. One after another they hurled themselves on my sedge. One after another they tried to pull it and the line and rod away from me. Huge fish too! And one after another they let go and returned to their other affairs.

At the end of all things I felt for my line in the darkness, in order to take off the cast. I pulled the gut gingerly through my fingers, as one does, that the hook might do me no damage. And there was no hook! There was a sedge all right, but it had lost not only its point and barb, but even the bend. It was just feathers and silk on a piece of straight. wire.

I remember that I was profoundly moved by that evening, so moved that I reported the whole matter to headquarters, so to speak. I wrote to F. M. Halford about it, letting him know generally what I thought of the evening rise as an institution. I 
wrote very strongly, asking what he thought we could do about it. He replied to the effect that the best thing we could do about it was for the future to "Keep quite calm."

If memory serves me, Scott's little friend Marjorie Fleming, in precocious rhyme, immortalised the fowl who was " more than usual calm, She did not give a single dam," when the ducklings undutifully made for the water, or when some other domestic event happened, whose precise nature eludes me. Halford meant, of course, that I should be excecding calm like that, even when my fly undutifully sought the thistles, or when other untoward things happened. But he meant more. I might conceivably win through an evening rise without profanity, but, as for keeping quite calm, that is another thing. For, though I have seen many an evening rise and occasionally done right well, it passes my skill to grect a new one with calmness unless for some reason I do not particularly want to catch fish, which almost never happens. Usually I want to catch something very badly, because tea time has found me a shattered wreck with nothing in my creel. And my proceedings during the stages of the rise are too often as follows. The evening rise, as said, begins at 5 p.m. Its first portion consists of a few, very few, depressed fish making tiny dimples at nothing. As also said, I cannot catch these fish. I usc a 
hackle red quill on a "short" 00 hook, which I flatter myself is no bigger to a fish's eye than a 000 . I do not use it, though, till I have put a black smut on the new point, looked at it distrustfully, and then taken it off again untried. This custom is almost invariable. The mental process is something like this : "That is the sort of fish that wants a black smut. This is the black smut it wants. Good. But, come to think of it, does the fish want a black smut? Ought it to? The black smut is a thing for the daytime. It is true that the sun is burning a hole in my back, but this is the evening rise. No, a hackle red quill is what must go on." So it goes on, and as exactly as I can I have told why.

To continue, the depressed fish go on dimpling, " here a trout, and there a grayling," till about six. By that time $I$ have put a selection down (boasting, however, one short rise), and the others have gone down of their own accord, or by the laws of gravity. Then I go on to where, on a swift shallow, are what an ingenious friend calls the "decoys." These fish rise always, morning, evening, night, hail, snow, shine, or earthquake-at least, I believe so. They constitute the second period of the evening rise. On this shallow I always see two light-coloured duns, and I always say : "Ha! It's beginning." They are decoys, too. So I put on a ginger quill, and a pale watery, and a Wickham (which is so good for 
chance fish), and a sherry spinner, and one or two other things. The period ends with the decoy trout not quite so exuberant as they were and a winged red quill on my line.

I come now, having left the decoys, to the third period. This begins with me sitting on my basket at a bend in the stream favourable to observation, and saying to myself that the two light-coloured duns were one of Nature's accidents. I then tell myself that I shall do no good by wasting any more energy till the rise proper begins. The wise man sits on his basket, and takes the gut ends out of the eyes of flies which he has been changing. So, this decided, I spring up and rush feverishly to the top of the water to sce if the evening rise is beginning there. As I go I change the red quill (which has not yet touched the water) for a blue upright. It is a fumbling business to change a fly as you hurry along, but it saves time perhaps. As I come back from the top of the water the blue upright is changed for a sherry spinner, beeause, of course, that is the fly that is going to do the triek when the fish begin. So the third period ends, with me sitting on the basket and a sherry spinner stuek in a ring.

The fourth period begins with me standing watchful at a bend of the strcam, thoughtfully changing the sherry spinner for a blue upright, a fly in which I have the utmost confidenec for evening work. 
It ends with me standing on the qui vive a hundred yards higher up. I am, if you do me the honour to observe me, changing the blue upright for a Tup's indispensable.

Now, at last, somewhere between half-past seven and eight, begins the fifth period. A rise, two rises, three rises, and there are flies of some sort, transparent things, dancing in the air. So I change the Tup for a blue-winged olive (which every one knows to be the evening fly for July), and proceed laboriously to put the fish down with it. I do not realise that I am doing so, of course. A series of mischances is attributed to unskilful casting, shyness of the fish, to anything you like. Presently the blue upright is given a trial, and it gains two or three short rises. The hackle red quill is of no effect. In a flash then comes the realisation that the sherry spinner is, of course, the thing. It goes on, and has not the slightest result. Then I remember that those transparent things in the air were spinners. The flat-winged imitation ought to have been tried three-quarters of an hour ago, not now, when the spinner is all over.

So now we enter upon the sixth period, when the fish are really rising and the light is growing less. What are they rising at? The blue-winged olive. Am I keeping quite calm? No, I am putting on a sedge, and a black smut, and a red olive spinner, and 
a blue upright, and a Wickham, and a red quill, and a cochybonddu, and a coachman. And the fish are disdaining each with a deeper disdain, or being terrified of each with a greater terror, according as is their mood.

The seventh period begins with a slackening of rises as the fish find the blue-winged olives petering out. Precisely as the rise ends I remember what is the fly, and get it on to the cast somehow in the gloom. Looking along the path of light towards the west, by good luck I see a quict dimple, at a sedge of course. The blue-winged olive reaches the spot, is taken (because darkness covers many sins), and the miserable little hook fails to hold the fourpounder, for which I have yearned all the season. A good, sensible sedge on a No. 4 hook, and the fish would have been mine. That scdge is put on now at last with the aid of a match, but it is too dark to see any more. So ends another evening rise.

I will not pass on Halford's advice to any distressed reader. If an angler loses his calmness during the evening rise I say that he is quite within his rights. I am not sure that it is not his duty so to do. Nine times out of ten it is a maddening business.

Two special evenings remain in my memory as illustrating how tantalising evening fishing can be, 
though they remain with me pleasurably. My feeling in regard to them is awed rather than indignant. I was fishing a river which had suffered grievously from pollution, and which was supposed to have lost a large part of its stock of fish, either because they had migrated downstream or because they had been killed outright. My impression at the end of a long hot tramp of some miles was that there was truth in the story of pollution, that the big trout and grayling had mostly disappeared, but that things were now improving. I had seen a sprinkling of small trout and myriads of tiny grayling. But as for sport I had had none.

By the time the day was dead, and the evening moribund, I reflected that the fishing had been very much likc the day, for hardly a rise was to be seen anywhere, at any rate from anything of more than six inches long. Perpetual observation of a river which is dimpled in all directions by grayling under that length is trying to the temper, especially when you suffer all the time from great heat accompanied by a thundery sort of glare. Even the most optimistic angler gets tired of casting to those dimples and pretending that they are worth the trouble.

But now all that was over and the evening also was drawing to a close. It had produced one disaster, a two-pound trout which had unhooked himself after taking an orange quill, and further 
there had been nothing. The whole side stream had been patrolled without the sight of another fish, and now I stood at the head of the hatch-hole wondering what I had better do, whether follow the main stream up against the light or go quickly back and go over the side stream again.

Nothing of course was rising in the hatch-holenothing ever does when you are on the spot. Besides it is not a "rising" sort of place, small, deep, turbulent, and very difficult to fish without a drag. Only in the right-hand corner is there anything like a steady bit of stream, a short narrow run just towards the eye of the eddy where it meets the foam. It is the sort of place where a good trout might rise, and where a good angler might be cxcused for missing him. To cast a short line from the wall above across a clump of rushes and hanging grasses and also over a belt of drift weeds on to a rather rippled stream, and to make sure of "converting " a rise, is not an easy matter.

The eye surveyed this place disparagingly. The hand to which the eye belonged had made sad bungles of similar places. And anyhow there was nothing rising. But, stay, what was that? A trail of dark weed? Surely. And yet-and would that be another trail of weed a bit further out and higher up? Confound the light, or rather lack of light! Who could be sure, looking southwards 
at this time of a thundery evening, what those shadows might be? But ha! Trails of weed do not shift their position. They waggle sometimes, but they do not move their centre of gravity. Have at them!

To be brief, it proved that the two shapes belonged to two great red trout which had come up from the foaming depths to lie "at the ready" in the backglide. And an orange quill made one of the shapes tilt upwards at the first offer. And at the next there was a disturbance among the ripples, and the raised hand felt, just felt, a rock-like resistance. One of the monsters had been risen and lost. Then the atrocious light gave out and nothing more could be seen.

Next evening - the day had been almost as dead as its predecessor-was better and brighter, and the point of observation was reached earlier. Ye gods, what a sight! Not two, but four great red shapes lying in the narrow strip of backwash with a vague suggestion of a fifth beyond. There was only just room for them, and now and then one would cruise out to the cheek of the eddy, now and then one would drive another away. Believe me, it is an impressive sight to see a trout of five pounds four ounces giving the cold shoulder to a trout of five pounds two ounces. It makes the spine crawl with varied emotions. And presently, swimming tumultuously 
across the centre torrent, came for a brief instant into the field of vision a huge whitish figure which positively dwarfed the others. But it sheered off again and was seen no more.

As for the capture of a brace or a leash of these prodigious fish I have no intention of relating it. All flies, of course, were tried, tried with fury. Some of them tilted a nose or so. One, and one only, opened a cavernous pair of jaws. But eventually the light failed as before, the shapes faded from view one by one, and the opportunity was gone. Never have I known anything more tantalising. For I am sure $I$ have never in my life seen so many really big trout at such close quarters, or so massed that one fly might conceivably rise any one of them. In sober earnestness I believe the smallest of the lot was well over three pounds.

The rest of the evening, about half an hour when facing the afterglow, was ridiculous. I settled down to besiege a big trout in the main river rising close under my own bank. Sometimes he came up with a resounding plop close in, sometimes more gently about a foot out. I tried five different patterns over him and finally hooked him on a blue upright in the outer position. He jumped when hooked and fell in again with a miserable little splash. There had been two fish, great-grandfather and greatgrandson, rising side by side, and my long and 
conscientious efforts had been rewarded by the latter. And so home.

I shall never solve the mystery of those great fish in a river which was supposed to have lost its stock. I should have been tempted to think them ghosts but for the fact that I felt one of them. Their appearance under water was strongly suggestive of the phantom ships in the late Mr. Hope Hodgson's extraordinary book The Ghost Pirates. Presumably what had happened was that the pollution had been enough to kill the fly-food of the river down for a time, but not enough to kill the big trout. They possibly took to bottom-feeding from necessity, and so to a large extent vanished from human ken. In that part much of the water is deep and heavy and trout resolutely near the bottom would be quite invisible. 


\section{CHAPTER VI}

\section{THE FLY QUESTION}

Tine story of the message sent downstream by G. S. Marryat to Francis Francis, who had inquired what fly was responsible for the master's visible and tantalising success, scems to me to enshrinc a considerable truth. Marryat, we are told, said that the responsible agent was " the Driver." Whereupon Francis asked what that might be. So a sccond message came down, "Tell him it's not the fly but the driver."

The fly question has probably produced more puzzlement and brain-storms than anything elsc in fishing. It seems absolutely impossible to reduce it to anything like a clear and simple system. Even when, after many years of experiment and the collation of a great number of experiences, one has apparently succeeded in evolving a few general rules, the chances are that the next day's fishing will make it necessary to revise them. The fish will very likely refuse to have anything to do with the patterns which one has just decided to be the foundations of piscatorial faith. In despair one 
looks through box or book again, finds some antique or some exotic which has lain therein absolutely neglected and despised, puts it on as a last resource, and discovers that here is a new-fangled medicine worthy of a hearty testimonial. This sort of thing must happen to everybody, and it is very upsetting to all plans for reducing things to a system.

Undoubtedly, the case is much worse for the angler who is dependent, as I am, on flies tied by other people. Of the five or six superlatively good trout fishermen whom I know well only one is not a fly-dresser, and that one knows exactly what he wants when he gets his flies. I suspect him of having at any rate passed his apprenticeship in the art in earlier days. Most of us, however, who cannot tie flies are not quite sure what we want, and in consequence we get a great many things that we do not want. I possess an incredible number of abominable productions which call themselves flies, purchased at various times in foolish faith that they might come in handy. This is bad enough, but it is much worse that one or other of these monstrosities will sometimes in the most insolent manner prove itself capable of catching fish when other more respectable patterns have wholly failed.

One of the most scandalous instances of this occurred on the Penydwddwr some years ago. It 
was at the end of April, and we had been having a grievous time owing to the wintry weather and lack of fly. Our united catches had for some days barely found us in breakfast, and we had got into the habit of going out each morning without any hope of better things. One morning I started thus handicapped (and more, for I was afflicted with a chill as well), and flogged aimlessly downstream with the usual assortment of flies and the usual lack of result. Then something indueed me to put on the Bottle-brush. I have always thought of it as the Bottle-brush because it has no other name and deserves none-had rather; it is now no more. This ereature was two sizes larger than anything else in my book and was an unpleasing brown thing with an inordinate quantity of stiff stark hackle and no wings. It was exactly like a bottle-brush in shape. Supposed to be a wet-fly it would have needed a small paternoster lead to make it sink. I never met with a pattern I disliked more on sight. Well, I dragged this thing about the river in a halfhearted way, and presently a trout hurled himself upon it. I basketed him, and soon afterwards another, and more followed until I had amassed sixteen of excellent size. Then the disintegration of the bottle-brush was complete-it was badly tied as well as horrible in appearance-and thereafter no more could be done. But I had the best 
basket, for quality, that I ever achieved in that small river. The sixteen compared favourably with the threes and fives that the other anglers produced at tea time. And it was all due to a fly which I should never have dreamed of putting on had I not been dispirited and unwell.

I can remember a somewhat similar surprise on the Kennet a good many years ago. This was due to a red spinner. Your red spinner is a good fly and a pretty, but for dry-fly work it should observe certain conventions. This specimen did not. It had a drooping whisk of soft hackle set rather askew, and a pair of towering massive wings. It dated from the days when professional fly-dressers (or some of them) used to say to themselves, " $\mathrm{Ha}$, a dry fly! That usually has double wings. Let us treble them that it may hum in the air the better and bounce upon the water." Adding just a memory of hen hackle to make the creature fly-like, they issued it to the unsuspecting, who assumed that a dry fly owed its dryness to its bulk of wing. Such was the red spinner which I tied on for the usual reason that I could do no good with anything else. And such was the red spinner which, floating sideways or upside down, secured me two brace of good trout that had refused all kinds of properly dressed flies.

Incidents of this kind are no doubt common to the experience of every fly fisher, and they seem to 
me to prove that trout are more than a little prone to run after new things, an error of judgment which undoes them as it undoes human beings. This is more the case probably on waters which are pretty hard fished. There the inhabitants undoubtedly get to know a great deal about the conventional patterns which are so much brought under their notice. Give them something new, however, and they will occasionally display extreme foolishness.

One of the experiences which has given me most satisfaction was something of this kind. It was the first time I ever visited that famous bit of ticketwater at Winchester known as Chalkley's. I knew it by repute, of course, as an extremely difficult fishery, where, for a new-comer, the capture of a trout was esteemed good work and of a brace fine sport. The fish were plentiful and they rose freely, but they had been edueated with all the thoroughness that befitted such a home of learning as Winchester. I approached the water in consequence in great humility, and was not surprised to find that ginger quills, red quills, and the rest made no impression on the tantalising creatures that I could see rising. After half a day I retired worsted. The morrow, however, found me there again still full of zeal and eager to try a new plan. 'This was to give the trout something to which they were not accustomed. I had gathered from conversation with some of the 
habitués the day before that most people fished with winged-flies, and I thought I would try the effect of tiny hackle patterns. The result was a modest triumph of two brace, besides which there were two or three decent fish lost owing to the inadequate hold of the small hooks. As a stranger I felt that I had done very well.

This is not, of course, quite the same thing as surprising the fish into taking by offering them some strange new thing, for tiny hackle patterns are nothing startling. The startling fly, however, does succeed. A good many anglers must remember how for a series of years on the hard-fished water of a certain well-known society the ingenuity of one or two members used to be directed to inventing new flies, which proved very successful. Some of those flies were strange enough to deserve the names which were given to them- "terror," "paralyser," and the like. But they killed fish. It may perhaps have been due to the energy of the chief inventor in designing new patterns and so making the earlier successes seem old-fashioned, but my impression used to be that each new fancy outlived its usefulness by the end of a season, and that next year something different would do better. And I still think that the trout after a time got to know a fancy pattern too well and distrusted it. Such a thing is perhaps more noticeable in lakes where the wet flies used 


\section{THE FLY QUESTION}

are chiefly of the fancy pattern kind. Some startling new fly will often succed very well, noticeably well, for a time, but in duc course it loses its magic and becomes no better than one of the dozen or so of general patterns which are generally worth trying. Blagdon Lake has known several ups and downs in fashion of this sort.

But I have little doubt that, generally speaking, there is considerable merit in something new in fly fishing for trout, and that an angler who finds himself at a loss on some occasion would do well to try the effect of it. Of course the novelty need not consist in purely fancy attributes. There is a much more effective kind of novelty in an attempt to copy a natural fly by some new method, or in the use of some material for body or wings which has not often been seen on the water you are fishing. This is where the man who can tie his own flies seores so heavily. He need never be satisfied with a rendering of a fly which scems to him inadequate, and he can always be trying the effect of some slight change. He probably has his materials with him, and he can do it then and there when an idea comes. The rest of us have to wait patiently while some one else does it for us, and at the quickest the obtaining of a new fly takes several days.

The longer I fish the more I see the value of skill in fly-tying, and were $I$ to begin over again, I think 
I would learn to handle fly-dressing materials before I learnt the management of rod and line. I do not think that a man enjoys his fishing any the less for not tying his own flies, nor do I think that he would save much money by tying them (for cabinets, materials, tools, silks, and the other paraphernalia are attractive enough to induce lavish outlay), but I do think that he must be less efficient in the art of catching fish if he cannot himself construct the lures with which he pursues them. "But think," some one may say, " how many fine fishermen there are who have this disability." It is true, but it is no less true that if they were fly-tyers they would be better fishermen still. And I fancy there are very few of them who would not admit it.

Occasionally the question, a curiously interesting albeit not a very profitablc one, has been raised as to what trout-fly individual anglers would select if they were confined to the use of a single pattern for a whole season. The problem is as difficult as the other test of irresolution which seeks to pin a man down to the choice of a single book for a sojourn on a desert island. To the individual who finds neither the hundred best patterns nor the hundred best books enough for his normal requirements, such a making-up of the mind would be a fearful proceeding. But of course for academic purposes and with the comfortable certainty that 
one is not likely to have to put the matter to the proof it is amusing sometimes to dally with the idea. Moreover, there are anglers who have fished a season through with a single pattern, or with but one or two changes. Lord Grey in his book on fly fishing has set down a short and simple list of flies which comes very near the single-fly ideal. For dry-fly work he expressed his content with four patterns (besides Mayfly and sedge), to wit, medium olive, iron blue, red quill, and plain black hackle. For wet-fly fishing his selection was Mareh brown, Greenwell's Glory, the Pennell No. 1, red quill, and black spider. W. C. Stewart evidently favoured a short and simple list for his own use, and he advocated but six patterns.

That veteran angler and writer, "Red Quill," once described in the Field the result of a season's dry-fly fishing in which he used but a single pattern, the fly which gives him his pen-name. And there are a certain number of single-fly men about. A friend of mine had for some years one unvarying reply to the question "What did you get them on?" It was "A Wickham." He may sometimes have used some other pattern, but I never saw anything else on his cast. Another friend of mine in answer to the same question might be depended on to reply, "A red tag." And a few years ago on a wet-fly stream in the spring I met an angler who told me 
that he always used the coachman. I think he always fished it dry wherever he might be. And though my memory of that visit is one of rather inclement spring weather, when one would have said that dry-fly fishing would be badly handicapped, that angler certainly used to bring back fish, not many perhaps, but good ones. I fancy he gave himself a biggish size-limit. My red tag friend is similarly a devotee of the dry-fly method, and I know that he has done quite well with his red tag on all mountain streams as well as in the chalk district, and likewise with coarse fish, for which he also angles.

At one fishing inn which $I$ have often visited a certain angler has left an enduring reputation behind him. I never had the pleasure of meeting him, for his visits had ceased shortly before mine began, but I know him by repute as well as any angler in history-so often have his name and achievements come up for discussion in the smokingroom of an evening. Never did any visitor at the inn ever bring back such distinguished troutindeed I am not sure that he did not achieve halfpound averages, which is a thing almost incredible in that district-and, his chroniclers will always conclude, "he never fished with more than one fly, a very big cochybonddu." Early spring, high summer, or cool autumn, it was apparently the same 


\section{THE FLY QUESTION}

at all times, a very big cochybonddu, and baskets of trout with which no one else might vie. Yet another angler once told me that he always fished with a single pattern everywhere, a plain black hackle with silver ribbing down the body, and he scemed quite contented with the results of this procedure.

Probably there are plenty of other anglers who have reduced their perplexities to nil by a similar resolute policy. I remember that my friend Caradoc all one season on a chalk stream which we fished together seemed to use nothing but what he called "the haystack" -it was a bunchy sort of hackle hare's ear, if I am not mistaken, but I took a dislike to its appearance and shape, and would have nothing to do with it. When 'Tup's indispensable first dawned on the dry-fly world a good many men must have used it pretty consistently in the same way. The river reports were for a long time full of the doings of this excellent fly. And there are other instances of the same kind of thing. One very famous fishing club would probably be willing to pass a unanimous vote of thanks to the fly which has the inspiring name of "the extractor" ; though I fancy that that particular pattern has since had rivals in the general esteem, it is still good for a brace most days.

Reflecting on such examples of procedure as those 
on which I have touched, one cannot help coming to a conclusion that one ought to be able to simplify one's method without any great loss to one's take of fish. If different men are able to go contentedly on with single patterns so diverse in character as Wickham, red tag, coachman, and silver-ribbed black hackle, the implication is that, take them by and large, trout are not a fastidious race. And so the ordinary angler need not, unless he chooses, embarrass himself with a confusing mass of patterns which many of them have but small points of difference. Which is as much as to say that the brief list advocated by some writers is sound policy after all.

Looking at one's own customary procedure one is on the whole strengthened in this belief. The flies which I use most are as follows: 1, olive; 2 , red quill ; 3 , Wickham ; 4, blue upright; 5 , hackle red quill ; 6 , black hackle; 7 , half stone; 8 , orange quill; 9, blue-winged olive; 10, March brown; 11, orange partridge; 12, Greenwell; 13, hare's ear; 14, cochybonddu; 15, blue dun; 16, February red or early brown. Of course there are other flies which are on my cast occasionally, and I would not venture to say that at some future date the list given would not have to be altered or modified. But so far as my present practice is concerned these sixteen patterns are the flies on which I chiefly 
depend. Nearly all of them scrve both for wet and dry-fly work, with, of course, the necessary difference in build in the case of the winged flies. And nearly all of them are applicable for either chalk streams or mountain rivers. Some of them serve equally well for lake fishing, though for that I would add a few purely fancy patterns which I should not think necessary for river work, and also one or two imitations of the gnats and midges which are important on still waters.

There is, to my mind, no hard and fast line between chalk streams and other waters in the matter of appropriate flies, and a pattern considered specially designed for one district may do equally well in the other. The half stone and the blue upright convinced me of this. Both are essentially Devonshire flies by tradition. But both are extremely valuable for chalk stream fishing. The pattern of half stone which I use is as a matter of fact a Welsh dressing, bigger and more straggly than the Devonshire variety, but it is practically the same fly in essentials. It is not particularly like anything you find on a chalk stream, but the fish scem to take to it very kindly whether fished dry or wet in the minor tactics fashion. It must be an excellent instance of the typieal fly. I have not the least doubt that many of the essentially wet-fly patterns of which there is such a large variety would give 
surprising results if introduced to the Test or Itchen. Some of the Yorkshire patterns, for instance, have every attribute that ought to command success. And in many cases the skimpy build of a wet-fly seems to be an attraction. If it has no wings that does not prevent its floating. Life is not long enough to try any great series of experiments of this kind, but so far as I have experimented I am convinced that a good fly will kill trout anywhere. As for the "local pattern" I have no belief in it as a sort of talisman for a particular district. Given a good set of typical flies, a reasonable measure of skill in using them, and a knowledge of water craft, an angler will always give a decent account of himself anywhere. The undue exaltation of local patterns is due principally to the skill of local anglers who know every yard and every mood of their own waters. There a stranger must always be handicapped, and blame for his comparative lack of success may be ascribed to his flies rather than to the proper cause.

The best test of the matter would be to take away the local patterns of some skilful local angler and equip him with a set of flies from some district where a different convention of imitation prevails with a similar result in the glorification of certain dressings. Provided that he was not so conservative as to despair of new-fangled ideas at the outset, I would 
wager on his doing just as well with the new equipment as with the old. This, of course, applies to districts in which conditions of water, etc., are more or less similar. But I am also convinced that if you took a really skilful wet-fly man, told him the rudiments of dry-fly practice, gave him a tin of grease for his line, and set him loose on a chalk stream with his own patterns, he would quickly find himself on excellent terms with the trout. In fact, I have seen that occur more than once.

I have dwelt on the difficulty of systematising one's selection of a stock of flies owing to the way in which some pattern heretofore little esteemed may suddenly justify itself by a marked suceess. For all that, however, I suppose every angler has his favourites, and I certainly have mine, the result of gradually accumulated experience. On the whole, I think, my tendency is to reduce rather than increase their number; though now and then some new one may be added, it probably replaces an old one or at any rate detracts from its importance by doing part of its work. Of course it would not be easy to set down a dozen patterns either for dry-fly fishing or for mountain streams and say that these met every possible need. They would not, and the heterogeneous array in box or book proves that they would not. One carries a great many patterus which one seldom uses and in which one has no great 
belief for ordinary occasions. But one recognises that they may be required some day, and possibly one has memories of days on which they were essential.

Some of these flies are possibly only needed if one is on the water at a certain time of year. The grannom, for instance, is a creature with a welldefined season, often a short one. Where it occurs you generally know when it is due more or less. So too with the Mayfly and Welshman's button on the south-country streams, and such a fly as the gravelbed on some of the mountain rivers. Other flies, which also have definite seasons, aceording to my experienee may or may not be wanted. Inseets like the hawthorn and the brown ant are about each year at their special times, but it does not follow that they come within reach of the trout. If they do you may want imitations of them very badly. I have once or twice been very glad of having a few imitations of the hawthorn in my fly-book, and have owed a modest basket or so to its agency.

But the most noteworthy instance of its value that I ever eame across was not a personal experience. This was on the Exe in May. It was lovely weather, the water was rather low, and the halfdozen rods at the hotel had for some days been doing but moderately. I myself had been eounting my 
catches by the brace, a fact which tells its own tale, though I had no reason to complain of the sport, as the fish reached a very good size for the Exe and gave great fun on gossamer tackle and tiny flies. One of my fellow-anglers attraeted my attention. He obviously knew all about it, but he took things very easily, did not seem to care whether he caught anything or not, pottered about a good deal, and appeared to do more watching than fishing. Then suddenly one day he addressed himself to the business seriously and returned with a splendid basket of trout-over two dozen, I think, and of good average size. He confided to me that the hawthorn was the fly, and added that he had been waiting for the opportunity. It has always struck me as one of the most scientific fishing achievements I ever came across-waiting patiently till the chance came, and then using it to such good purpose.

I have never had the luck to find the hawthorn causing chalk stream trout to rise, though I believe that happens sometimes. Nor have I ever seen a big fall of ants on the water, though I have occasionally found the ant a very useful fly towards the end of August or beginning of September when the inseets have obviously been about. The alder, of course, has served me very well in its season, but for a long time I must have given to it eredit which 
properly belonged to the Welshman's button or caperer. I am not sure that the latter name is not preferable on account of the confusion between the Welshman's button of Hampshire and that of Wales. Anyhow I had no knowledge of Sericostoma personatum till Mr. Halford's new patterns opened my eyes. Since then for chalk stream work I have used it far more than the alder, principally because I find it easier to see. It is not necessarily more effective. More than once when I have been killing fish with it I have afterwards found that another angler close by has been doing equally well with an alder of the same shape.

The cowdung fly is one for which I have an affection, though I have used it but little of late years. I have memories of cold blustering days in early spring when these brown-coated creatures of dubious habit were about the only sign of insect life. A certain number get blown into the water, and so on such days the pattern is certainly useful. It has given me a good many trout in the past, and so I generally have a few in my book in the present. The zulu is another fly of which I always carry a few examples both for wet and dry-fly fishing, though I do not often use it now. But I have once or twice found it very valuable as a wet-fly when the water has been rather thick, and, as for dry-fly work, I 
always remember that a friend of mine got a fish of well over four pounds with it on one occasion.

Setting aside the comparatively fow anglers whose practice is really seientific and who have and use a wide knowledge of fisherman's entomology, I suppose most of us are more or less guided by the rough general principle of wishing to use something more or less like what the fish happen to be taking at the time. And I suppose that I am not alone in believing that on a good many occasions what one may call a "typical" fly is good enough. Supposing, for instance, that there are lightish olives on the water, it would not be surprising if the trout were equally ready to take a light olive quill, a ginger quill, a hare's ear, a light-blue quill, or perhaps some other variety of cock-winged dun, supposing all the patterns to be of the same size and shape. Any one of these patterns presumably gives the fish a representation of the natural fly good cnough for their needs. At one time I pinned my faith to the ginger quill as the typical pattern and had no cause for dissatisfaction. Then Mr. Halford brought out his new patterns, his medium olive took my fancy, and since I have hardly used the ginger quill at all. I must confess that I have never found any difference in the killing power of the two sexes, but I have used the female most as it has a slightly more 
toothsome appearance-a thoroughly unscientific reason!

As a general rule I am not much impressed by any tendency in trout to be over particular as to shades of colour. The ginger quill and Halford's female olive are not a bit alike in colour, but the latter seems to me to do the work which used to be done by the former. And I think a light hare's ear would probably serve me just as well. But-and this prevents me being a hearty sceptic as to the colour question-I certainly sometimes find the fish inclined to pick and choose. Especially is this the case in the evening when the blue-winged olive is on. Several times I have proved that the trout would take Halford's blue-winged olive, the female, when they would have nothing to do with any other pattern I offered them. And I presume that the colour has been responsible for this, though it is marvellous that subtle distinctions, as between that fly and an ordinary dark blue quill or blue dun, should be perceptible to them in the dusk. But, to show how one's mind wobbles in these matters, I had just made it up to the effect that Halford's female blue-winged olive was the fly, when, as previously recorded, Mr. Skues introduced me to the orange quill on quite a big hook-No. 2, I think. This fly immediately ousted the other in my affections, 


\section{THE FLY QUESTION}

for it seemed a sure killer, and its size of hook was a great advantage for evening work when you want to hold fish rather hard and get them out quickly. And now - at any rate, for the time being-I have lost faith in both blue-winged olive and orange quill! Neither kills fish for me any more. But I have said all that I need say as to the uncertainties of the evening rise and the selection of patterns for it.

For a good many years now I have depended to a large extent for dry-fly fishing, and to some extent for wet-fly work, on a simple series of hackle flies, blue, red, ginger, and black, three of them with quill bodies, and the fourth with silk body, all rather sparsely hackled, and somewhat varied in shade. The blue, for instance, may be dark, medium, or light, and the red may be dark or light, and may or may not have a couple of turns of gold tinsel as a tag. The black must have jet-black hackle. The value of this series, which practically consists of wingless blue, red and ginger quills, and black gnat, is most apparent in hot bright weather, and smaller sizes are usually more successful than larger. The blue fly on a 00 hook $^{1}$ is particularly good in

1 With a view to getting more holding power in these small flies I adopted the plan of short-shanked hooks. 'The result of this is that with a 00 length of body you get a 0 gape of hook. Mr. Forrest, of Forrest \& Sons, Thomas Street, Oxford Street, W., kindly interested himself in the matter, and got some looks 
the evening rise, especially if rising fish are few and far between. The black one is excellent for smutting trout; indeed, all four have their uses in that emergency. I suppose that the success of the series simply depends on the fact that each fly is sufficiently typical of some series of insects, diptera as well as duns, on which trout feed. Oddly enough, though I have carefully tried a hackle olive of the same type I have never done any good with it worth mentioning. But Mr. Rolt's "Sylph," a little grayling fly with a green silk body, has sometimes been very useful, and ought perhaps to be added to the series.

At one time I found myself hoping that this hackle series would render floating winged duns unnecessary, but I have now relinquished that hope. Winged patterns seem emphatically better in certain circumstances, as when fish are rising freely at a good hatch of olives. Also, on some very shy day, when I expect the haekle series to do best, I occasionally find that the old-fashioned winged red quill beats them all. I also had great hopes of Mr. Halford's beautiful spinners when I first made their acquaintance. These dainty creations seemed likely to do all that could be required of a series of "typical" flies. But only one of them has really

specially made. They are round-bend, very light in the wire and you must not treat them too roughly, but for delicate work and shy fish I have found them admirable. 
done much for me, the olive (red) spinner. I have found that invaluable on many occasions, but I have been able to do very little with any of the others, and the old range of simple hackles still holds its own.

In giving my impressions on the subject of flies I am acutely conscious that they are only of value as showing what happens to one angler of unscientific mind. Many of the flies which I find unsuccessful, or, more probably, have never sufficiently tried, are greatly valued by others. When I look into such a volume as Mr. Leonard West's The Natural Trout Fly and its Imitation I sce a great variety of patterns which are obviously good killers and which have never come within my scheme at all. And then there are the new doctrines of "impressionism" in fly-dressing, set forth by Dr. Mottram and others, the chase of the silhouette, the fashioning of shaped bodies, the use of hackles fore and aft, and so on. Both for wet flies (nymphs) and dry flies I believe the new conventions are more likely to achieve accuracy in imitation from the trout's point of view than did most of the old ones Dr. Francis Ward's optical experiments taught us many things, but I confess that so far I have not found in practical fishing any absolute necessity to renounce the old in favour of the new. 
The fact is that one man can only get to know and fish with a certain number of flies unless he combines the longevity of Methuselah with the single-mindedness of Stoddart. And so the confession of such crude practices as mine must be woefully inadequate as a contribution to the fly question. 


\section{CHAPTER VII}

SOME CONTROVERSIES

IT is one of the proofs of the strong hold which trout fishing has on their affections that its devotees are at any moment ready to engage in prolonged argument about its various methods and devices. I suppose all of us have at some time or other upheld with vigour a point of view which has not commended itself to our very good friend and neighbour, and consequently been let in for that battle of irrelevancies which commonly constitutes the human disputation. The worst of argument is that people get led on by shecr lust of battle, and in the hope of scoring some minor point are betrayed into saying something which is in excess of their real opinion. That said, they are then under the regrettable necessity of stieking to it, have to find further support for it in contentions which are purely advanced for that purpose, and so end up in a thoroughly false position, ruefully conscious of the fact that they are now committed to a confession of faith which by no means coincides with thcir inner belief.

Probably that fine old battle-cry "upstream or 
down" has put more anglers into this quandary than any other. I have more than once been present at, even engaged in, arguments which have had some such conclusions as that, on the one hand, nobody but an imbecile or a novice would dream of fishing downstream, and A. may please himself as to which class he belongs to; while, on the other hand, if anybody ever makes a decent basket by fishing upstream, B. would be very glad to see it, that's all, and meanwhile he will be happy to wager any sum $\mathbf{A}$. likes to name that his friend $\mathbf{X}$. would fish against him on any day and any water and give him at least twelve tails and a beating.

The clear-water worm is another fruitful cause of discord. Start a discussion upon it and you will probably go away halting betwcen the two opinions -(1) that the clear-water wormer is on the whole the highest type of angling man, situate on a finer eminence even than the dry-fly purist; (2) that he is a gloomy survival of the troglodytes, whose motto was "Slay and spare not," and that he ought to be swept away by the broom of civilisation.

Then, when the light and heavy rod controversy raged a dozen years or so ago, I sometimes had a fear that it might at last develop into an argumentum ad hominem baculumque, in which case the heavy-rod man would have an obvious advantage not altogether justified by the nature of the dispute, 

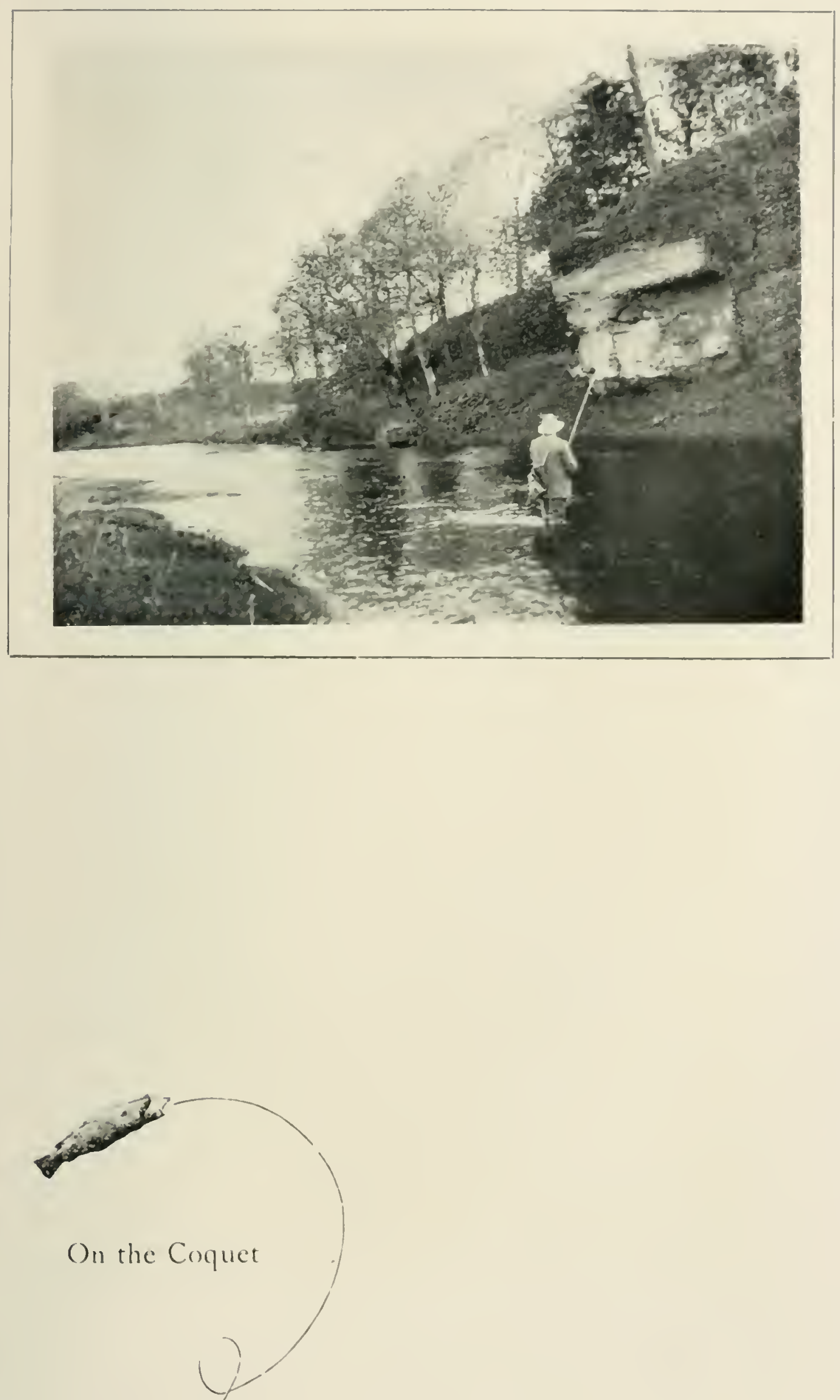

for a fishing-rod is, after all, intended for fishing rather than diseussion of the more violent kind. But of course almost any fishing controversy may end in a similar way if the disputants are by nature rather fierce. And something depends on the way in which the question is raised. When, for example, the fly-only salmon man says to the prawn-eumminnow salmon man, "Sir, your methods are damnable, and I have a great distaste for your personality, so now let us diseuss the question of "fly versus bait" "-when he begins in this way it is not surprising that the two fail to arrive at any sympathetic understanding of each other. And I do not suppose it is any more probable that they will do so if the discussion is invited by the other with some such words as, "Blank again? Well, if you will be such a benighted ass as to stick to your mouldy flies in water like this ..." etc.

Whether started thus provocatively or more mildly, as with, "My dear fellow, I should immensely value your opinion on a point," these discussions are always very interesting both to participants and onlookers. For everybody has, or has had, decided views on the main controversies which rage at different periods. But there comes a time with regard to most of them when the blessed word compromise seems a uscful addition to the other words which fly about. As one's fishing experience 
grows so does it seem more likely that both parties to a dispute have a good deal of justification for their opinion, and that the discreet third party by keeping his ears open and his mouth shut may learn not a little that will be to his advantage. It is perhaps indicative of a grovelling spirit not to plunge into any fray that is going on, but it keeps a man out of difficult situations, and enables him to turn a calculating eye on the profits of the affair.

Take, for instance, that " upstream or down" question. Suppose you have a skilled exponent of either method arguing on each side. By listening quietly to their respective statements you will probably pick up a good many wrinkles as to the conditions in which the two methods do best, and also as to the ways in which each man makes his own method effective. There was a time-I will admit it - when I was one of the upstrcam disciples, and so convinced that if I saw a man fishing downstream I immediately set him down in my own mind as evidently a poor performer. But that was a long time ago, and since then $I$ have angled in many waters, talked with and watched many anglers, and entirely lost my old attitude towards the downstream plan. At the same time, I have not lost my affection for upstream work, so I consider myself greatly the gainer. If one method does not succeed, to have an alternative method which may 
do better is decidedly a good thing. In the old days, if circumstances made upstream fishing impossible, it was a very half-hearted effort that I made in the other dircction. Now I should be just as hopeful whichever way I was casting.

Of course there are different methods of fishing downstream. You can, if you please, cause your flies to behave very much as if you were fishing in the other way. By casting across with a little slack to your line you can cause them to float down unimpeded for a few yards. I fancy this method, which is well suited to big rivers and deep or difficult wading, is the one that the crack downstream men mostly employ. In principle there is little to distinguish it from the across-and-up plan. But there are other ways of getting fish. You can work your droppers on the top, which is a pretty and sometimes a successful art, you can let your flies drag rcund in the stream, which rises fish well enough, though they do not always get hooked so surely as might be wished. You can cast your flies at an angle of forty-five, as in salmon fishing, and work them with movements of the rod-top. You can-if you come to a tunnel of bushes, a wide bridge, or some similar otherwise inacessible placelet a lot of line out on the stream and simply wind it back again, a plan which is often good for a trout or two. 
In fact, when one comes to consider all the possibilities of the downstream method, it is clear that deliberate rejection of it would be to inflict a voluntary handicap on one's efficiency. There are occasions on which it is not only just as good as, but even better than, the upstream plan. One of these occasions which has impressed me forcibly of late years is the period when trout are not definitely taking. If you have been fishing up for some time without stirring a fin, it is always worth while to turn round and fish down. Cast your flies under the bushes or bank and work them out and acrossstream with short draws of the rod-top, and it will be odd if you do not get a rise or two, and very likely in the same spots where the upstream method scored nothing. The movement of a fly fished in this manner may be unnatural, as some maintain, but it certainly has an effect on the trout, arousing curiosity at least, if nothing else. I do not know if wet-fly men at all commonly work their flies in this way-I rather think not-but the plan is well worth a trial by any one to whom it is new. I have owed to it many a brace of trout before the take has come on or after it has ended, which I am sure I should not have had if I had gone on plodding upstream.

One of the principal arguments of the supporters of the upstream method, as against the other, 
is that as trout lie with their heads to the current the angler is less visible to them when he comes up behind them. It is the sort of obvious benefit which I should never have dreamed of questioning but for an experience on a small mountain river during a period of dead low water and great heat one August. The stream was so fine and so clear that I found it impossible to cover the tails of the little pools even by the most cautious approach. Do what I would I could not get a fly to them without starting a sauve qui peut among the trout lying in the shallow water. They ran up into the pools, of course, and spread the alarm everywhere, so that, exeept for a chance with dry fly in certain places, it seemed hopeless to fish before dusk. But one day I tried fishing downstream, to see if it would be possible to get anything out of the stickles at the heads of the pools. And to my surprise I found that the fish were very much more approachable in this way. Indeed, at last I succeeded in killing some, though not many, and had to revise my ideas as to the invariable superiority of the upstream method on the score of visibility to the fish.

I have previously related an experience on the Kennet which also cast doubts on the visibility axiom. In that ease I should have said that fishing downstream I must be a much more visible object than when fishing up. But the trout did not behave 
as if this was the case. They fled when I was behind them, and they rose when I was in front of them, and I can only conclude that they saw me in the one position and not in the other. There is an interesting diagram in one of Mr. F. G. Shaw's books which shows the presumable field of vision of a fish's eye, and from it one may deduce that a trout can see much further behind him than would generally be supposed.

There is no up or down controversy among dryfly men, of course. Downstream fishing is a wellapproved branch of the sport, and it is only because drifting is a difficult art, and because it does not give much chance of a second cast at a fish, that it is not more generally employed. There are waters on which it scores heavily, especially in Mayfly time after the trout have been hammered very hard by many rods. Then they become extremely wary and suspicious of objects which are connected with some remote danger by a string. Offer them a fly, however, which floats down to them with its string tucked away behind it, and they may be more inclined to take it.

The question of the best kind of rod is another of those things which have led to controversy, but I think the debates have been more profitable than some of those on other matters, because they have undoubtedly led to definite results in the develop- 
ment of the most important item in the trout fisher's equipment. Had it not been for the "light v. heavy" war of pens, which I have before mentioned, I am pretty sure that I for one should not fish with half the comfort and pleasure that I get out of the sport to-day.

The old trout-rod was a heavy affair because it could not be otherwise. The convention of a gradual taper from a fat butt to a very fine point necessitated a liberal use of timber, and of course timber means weight. As we realise now, a great deal of this weight was quite unnecessary, since you can get a better action for ordinary fly-fishing purposes with much less taper and therefore much less timber. The typical old fly-rod had its action mostly in the top-half, and that of course is no sort of action for such a purpose as getting out a heavy dry-fly line against the wind.

The directions for casting a fly found in many of the older books of instruction suggest the proceedings of the novice who seeks to get his line out by making his rod, his arm, and himself into one rigid implement which moves slowly and gingerly backwards and forwards. He hopes, probably, that the wind, or providence, will see to the progress of the line in the right direction. I have often thought it a touehing instance of the vanity of human wishes when I have seen the ardent beginner leaning 
out over the water as far as he, and his arm, and his rod will go in the hope that thus he will achieve the further bank.

There is a line in Virgil descriptive of this situation: "Tendebantque manus ripae ulterioris amore." Many is the disquisition I have heard in the Sixth in ancient days on the poignaney of this simple tribute to the unattainable. But I think I never fully realised it till I had studied a few fly-fishing novices. The yearning countenance, the outstretched appealing hand (two hands sometimes), the futile dejected rod, and the miserable line cutting an eight, a three, a question mark, and a spread eagle on the surface of the water within a few feet of the hither bank-it is intensely Virgilian. It is the "alight like thistledown" nonsense which undoes the modern novice of course. He has heard that phrase from his youth up. He has gone into the meadows and studied thistledown floating gently on the breeze. And he has sought to make his artificial fly do the like, until it has dawned on him after much discouragement that a fly-rod is capable of doing some work, after which he gets on better.

The old rods would, of course, do some work, but not the kind of work one wants of a rod in many circumstances now. You cannot use a heavy line with a rod which does not play well down. The 
strain on the top part is much too severe. The lines such rods were accustomed to were light, made of horschair, or horsehair and silk, and propelling them was no great strain. Presumably their owners never attempted to fish against a strong wind, and if they wanted to make longer easts they used longer rods. That must be the explanation of the twentytwo-foot salmon-rods of which heroic tales are told. No one would fish with a twenty-two-foot rod out of sheer gaiety of heart, though possibly the actual labour of using it with a light line would be no greater than the labour of using a modern eightecnfoot rod with a heavy line. The common use of trout-rods measuring thirteen or fourteen feet was probably due to a similar need which exists no longer. Now that a ten-foot rod will east twenty yards with ease and comfort, there is no reason to be bothered with a weapon which requires two hands.

Not that the old-fashioned two-handed rod is without its uses still. To my mind it is the best possible weapon for lake fishing where you want to have a good reach, and to use fine gut. A twohanded rod seems to me better in boat fishing than a short rod, but if it is built on the modern lines it is apt to be too powerful for fine gut and small flies. In this respect the old light-topped rod is much more suitable. At different times I have 
purchased two modern split canes, fourteen feet and thirteen feet, primarily with an eye to lake fishing, and both have been failures for that. But both have proved fine little salmon-rods.

The fact is that with the new system of rodbuilding you can get too much power, and the old system still has its points of superiority for some kinds of fishing. A really good fourteen-foot troutrod of the old type is a treasure. For lake work and also for sea trout in some places it cannot be beaten. The same thing applies to salmon-rods also, of course. That is digressive in this consideration, but I may perhaps mention the case in which you have to fish a big river when it is low. You want a good reach of rod, but at the same time you must use a light line and fine gut. An old-fashioned eighteen-foot rod seems to meet the case better than anything else, for a modern fourteen-foot rod, though it would cast the distance all right and would not be too hard on the gut, would not hang the fly well enough. The same sort of thing has to be considered in trout fishing at times.

Generally, however, I am heartily in accord with the modern idea of what a rod should be and with the tendency to reduce all necessary weight. I often discussed this question with the late $\mathrm{Mr}$. Halford, who was by no means disposed to welcome the new light-rod ideas with enthusiasm. He used 
to point out truly enough that a well-built dry-fly rod of the type favoured by him did not feel heavy in the hand, because though it might actually weigh several ounces more than a modern light rod, a good deal of that weight was in the handle and so served to bring about a nice balanee. However, I always thought it a notable sign of the times that Mr. Halford himself eapitulated to the new movement to some extent. His later patterns of rod were much lighter than the earlier. I doubt if he would ever have come down to the half-ounceto-the-foot standard though. He liked a rod which was obviously powerful and which by its solidity of build gave him a feeling of mastery however hard the wind might blow. The dubious eye which he would cast on the kind of rod I generally fish with showed that he would have small confidence in it for rough work.

Personally I am, I suppose, what is called a light-rod man, and I simply would not fish with one of the old dry-fly rods if I could get anything else. But it is not the question of weight that seems to me most important. The quality I find in the light rods which scems most valuable is delicacy. For putting a fly to the proper place, for hooking a fish without fear of mishap, for playing it with judgment and a proper scnse of what strain you have got on, a sensitive rod is a great advantage. The bulkier 
and heavier your rod the less can you appreciate the subtleties of fly fishing. That, at any rate, is how it seems to me. The modern light rod of ten feet which weighs, say, six ounces, is to my mind vastly superior in this respect to the old rod which weighed twelve ounces or more. I do not say definitely that it will stand so much hard work or that it will throw so good a line against a wind, but I do say that it will enable a man to catch more fish, simply because with it he is on more intimate terms with his fly. With such a rod I use a slightly lighter line than I should with a heavier rod, and that of course is a help to delicate fishing.

I think the evolution of this kind of rod is one of the chief triumphs of tackle-making, and we certainly owe a debt of gratitude to America for stimulating our first interest in it. The slender split-cane rod, weighing little more than half an ounce to the foot, with a resiliency like steel and with what seemed almost miraculous power of casting, was a revelation to some of us at one time. But it has proved that there is no miracle about it, and our own makers now turn out light rods which answer every requirement of the angler's ideal. For all that we owe the impulse to America. So long ago as 1873 , when W. C. Prime wrote $I$ Go $A$ Fishing, our cousins were using seven-ounce rods. Twelve years later Francis Francis, in $A$ Book on 
Angling (sixth edition), was weighing the merits of four of his rods, which varied in length from eleven feet seven inches to twelve feet cight inches, and in weight from thirtecn ounces four drams to fourtecn ounees six drams. Not, of course, that light rods were unknown here till the American type was discovered. I have a little greenheart of nine feet six inches which is essentially a light rod and is perhaps forty ycars old. But it is not split cane.

While the gencral topic of fishing controversies is in mind, there is one which cannot well be dismissed as of small account, and that is the debate which arose a few ycars ago over the question of reintroducing the wet fly to the chalk streams, which had become more or less consecrated to the dry fly. The debate is, indeed, scarcely concluded yet, and I have no doubt that there are still plenty of dry-fly men who would bend a severe eye upon the minor tactician, as Mr. Skues's classic book leads one to call him. As I have frankly been a minor tactician myself ever since I read an article in the Field entitled "The Wet-fly Oil Tip," and even before that used to fumble after chalk stream trout according to my poor lights with wet flics if it seemed necessary, I suppose my consideration of the subject must be set down as a picee of special pleading. But it seems to me that we have a strong 
enough case for me to go forward in confidence none the less.

The arguments against minor tactics are mainly two, one that the method is of very little service, the other that even if it be of service it offends against the proprieties. The first argument seems to me unsound and the second absurd. To deal with them in turn : My own small experience has proved to me conclusively that you can catch chalk stream trout with a wet fly carefully delivered up or across strcam, and that the capture of an individual feeding fish is to be achieved in this way just as readily (in certain circumstances) as with a floating fly. I have heard some of the more rigid purists admit that a few of the smaller fish in a chalk stream may perhaps be fools enough to take a wet fly, but assert that nothing big would ever so far demean itself.

This by no means accords with the facts so far as my own experience has gone. The two-pounder is just as likely to take a wet fly properly presented as the pounder, and it is merely a question of finding cither in the right frame of mind. It may not be very important, but it seems to me to have some significance that both my biggest fish from the Itchen (they weighed two and a half pounds apiece) were taken with a wet fly. One was so caught more or less by accident-that is to say, I intended to put 
my hackle-fly over him floating, but it sank as it fell. The other was sought with a wet fly after he had refused two or three patterns on the surface. I have caught a number of fish of similar wcight on wet flies from both the Test and the Kennet, where the trout run to bigger sizes.

There is, however, no real need for me to labour the point that the new doctrine of nymph fishing is justified by its results when there is so convineing a book as Mr. Skues's Minor T'actics ready to any one's hand. Suffice it to say that I thoroughly agree with him that the method is an invaluable addition to the chalk stream fisherman's stock of subtleties.

The other argument of the "Non placets," that it is unsecmly to use a wet fly on a chalk stream in any method whatsocver seems to me to be based to some extent on ignorance of what this particular method really is. The ignoranee may in some cases be wilful, and reminiscent of the resolute mode of debatc charmingly summed up in a recent biography by "I'm not arguing, I'm tclling you." In such cases there is little to be said with any profit, because the most honeyed talk is of no avail with the deaf ear. But in other cases there is doubtless a genuine hesitation as to whether minor tactics is not part and parecl of the old system of fishing which eonsisted in raking about with a brace of 
big wet flies in windy or rainy weather, a method which our forefathers employed because they knew no better way of catching the fish, except perhaps the minnow or the worm.

The brief answer to this supposition is that minor tactics is different from ordinary dry-fly fishing only in the matter of the fly. You mark down your feeding fish, or your fish that looks like feeding, in exactly the same way. You take exactly the same precautions of approach, you cover him in exactly the same manner, and to the best of your ability you offer him an imitation of something on which he is feeding. But you so arrange things that the fly comes down to him beneath, instead of on, the surface of the water, because he is taking subaqueous and not surface food. This, at any rate, is a sufficiently accurate general statement of the case. Individual anglers may elaborate their proceedings by seeking to impart a little motion to their fly as it comes down, so that it may the better imitate a live nymph. Others may try to give an impression of " aliveness" to the artificial by careful selection and arrangement of the materials from which it is built. But without such elaboration the method briefly described will serve and will catch fish.

A point which I believe might weigh favourably with some of the opponents of minor tacties is the 
difficulty of the method. It is often a hard job to make your fly sink when you want it to. It is always a hard job to be sure when a fish has taken it under water in time for a strike to have the desired effect. The chalk stream as a rule does not help you to a conclusion as does a rapid mountain river when you are casting upstream. There any stoppage of the line is marked enough to be visible to the eye and often perceptible to the hand, while the rapid movement of the fish very likely causes a disturbanec in the water which is immediately noticed. But the chalk stream has not enough pace for the passage of the line to be of much help, while the fish, bcing more or less in a position to interecpt the fly just by opening his mouth, possibly causes no disturbance in the water at all. The minor tactician must make up his mind to be content with very inadequate indications of a rise, and he must expect, if things are not too favourable, to miss a good many fish which certainly take his fly and give him a chance of hooking them if only he could take advantage of it.

One does get a sort of instinct as to a rise with practice, but I am never quite sure how I detect one unless there is a definite commotion of the water (what you have to look for was recently celebrated in the Fly Fishers' Club Journal as a "wink under water"; it deseribes it very well) or unless I can actually see the fish. The last is the condition most 
desirable in this kind of fishing. If you can watch the trout you get an idea as to what he is doing, and can pretty soon make up your mind whether a dry or wet fly is more likely to suit him. And if you decide on the wet you have a very good chance of knowing accurately whether and when it is taken. You cannot (at least I cannot; very keen eyesight may stand a better chance) see the fly itself under water, but you know pretty well where it is, and if you see the trout turn to right or left and open and shut his mouth at about the right moment, you tighten up with a good deal of confidence that the fly is in the said mouth. Which generally proves to be the case. It is a fascinating sight to see a good fish come up at a dry fly, but I am not sure that the spectacle of the same fish turning under water to one's nymph is not even more attractive. It has an element of sporting chance in it which appeals to human nature.

Minor tacties, if the foregoing account of it be allowed colrect, is obviously a great advance on the old convention of wet-fly fishing in the chalk stream. But to my mind it is also, or may be, a great advance on the old convention of wet-fly fishing in mountain streams also, even on the upstream method which it so much resembles. I remember vividly one occasion when I was grateful for minor tactics on such a stream. It was fairly early in the season, but the weather was summerlike, and an evening 
rise was developing. I had come to a pool where I knew there were always a number of good fish, and these I found fecding vigorously in a sort of chain in the glide at the head. They were rising just as chalk stream trout do, and must have been lying close to the surface, though I could not actually see them. I tried them first with the three-fly collar which I had on the line, with no result beyond putting some of them down. Then I retreated to a rock, sat down on it, and told mysclf that this was just such an occasion as the dry-fly man in a strange country hopes for. And I made preparations for a bit of dry-fly work. Meanwhile the trout which had been put down seemed to recover confidence, and by the time I was ready all were as hard at work as ever.

To my disgust when the far-famed dry fly came to the test it was as futile as the three-fly collar had been. One or two fish seemed to push it (or them; there were several patterns) contemptuously with their noses, but nothing else happened. I had to own myself defeated, in spite of progress. But as a last resort, I decided to try a single wet fly, a small blue upright, fished as carcfully as I could manage it over individual fish. And this I did with the satisfactory result of getting five respectable fish out of that single pool, besides hooking and losing one or two more. It did not oceur to me at the 
time, but afterwards I realised that I had tried wet fly and dry fly in vain, and had finally scored by the use of what was really minor tactics.

To the really expert wet-fly man I expect minor tactics displayed in this way is nothing new; probably that it is his natural way of fishing in circumstances resembling those described. If he finds trout rising steadily he no doubt approaches them with very accurate casting and generally with a single fly. I should now endeavour to do the like, but until I had that lesson I used to blunder on with my two or three flies and often to wonder why visibly feeding fish gave such poor response. The fact that they are comparatively rare in mountain streams owing to the nature of the water encouraged this. If I failed in one place I merely went on to the next, so I never learnt anything about such fish.

There is, by the way, one more objection to minor tactics which is worth considering, and that is that it probably makes the fish shyer than they would otherwise be. I do not think it is possible yet to prove this one way or the other, because the art is comparatively new, and at most has only been employed occasionally as an altcrnative to dry-fly fishing. My belief, however, is that so far from making the fish shyer it might tend to improve their nerves. If you hammer away at bulging trout with a dry fly you are sure to make them suspicious 


\section{SOME CONTROVERSIES}

-every Mayfly season proves that anew-but I do not think that a wet fly, even several times offered, affects them nearly so much. They may not take it, but they seem to go on feeding unperturbed. And in any case it is a relief from dry-fly hammering, and so may even tend to improve the prospects of the dry fly when the fish are really on surface food. Time may show what the truth of the matter is. 


\section{CHAPTER VIII}

\section{MINNOW AND WÖRM}

IT is some time since I have done mueh spinning for trout, and a long time since I used to keep the apparatus for this art ready and in order. If I should happen to want to spin now I could lay my hand upon rod and reel, but it would be an arduous business to collect the other essentials. Somewhere, I know, there are spinning flights of various kinds and sizes, somewhere there should be an envelope full of traces, somewhere there is a varied assortment of artificial minnows in a state of more or less dilapidation, but I could not say for certain where most of these things may be. Time was when I had most of them ready for use and took them out several times in a season, but now spinning for trout is only a very occasional thing with me.

This is decidedly not a matter of principle, rather of circumstance. For a good long time I have had very little to do with waters where spinning is a seemly and possible thing. But supposing that Fate again cast my lines for me at all frequently in the Thames or some such river they would often 
have spinning baits at the end of them. Not that previous experience of the Thames has encouraged me to boast much about that water. My total catch of Thames trout could be counted on onc finger of one hand. And my only claim to distinction in this fishing is that my capture is the smallest authentic Thames trout on record-at any rate $\mathbf{I}$ do not think any one else can have landed one of seven and a half inches in a district where there had been no restocking with yearlings. Somcbody may counter me with the proud claim of a six-inch specimen, but if so I shall be surprised, and anyway I hope he will be no more able to produce his evidence than I am to produce mine.

The Thames has treated me very badly, for I have done a ccrtain amount of angling for its trout on and off. For two or threc ycars a weck-end cottage on an upper reach gave me opportunity, and I made fairly diligent usc of it, both with spinning bait and fly. But I never even hooked a fish at that time save the baby mentioned, though one day I had the excitement of seeing two pretty big oncs roll over at a gold-bodicd salmon-fly, unhappily without touching it. And I had other thrilling times too. Well do I remember two or three summer evenings spent on Benson weirpool, and the really alarming sight when just before dark heavy trout came on to feed in various portions of the big 
pool. They made a tremendous pother for their size, and it was quite nervous work casting for them. I do not suppose that I covered one properly at all, for very odd things kept happening to the reel and line, over-runs, tangles, and so on. I had all the time, too, a feeling that it was quite useless casting to a spot where a trout had shown, because by the time the bait reached it the fish would be somewhere else. The period of feeding was very short, not more than twenty minutes each evening, so I never scemed to have a chance of getting cool and deciding on a definite policy. Good resolutions formed earlicr all went to the winds. If I could have the time over again I would "lay for " the fellow who jumped off the weed-bed in the neck of the pool and try to ignore the others. I am sure he was well into the 'teens. But I never got a bait near him.

I suppose most Thames weirpools contain a number of big trout. Certain it is that they all have a number of assiduous anglers. Except for the period in the Benson district I have only fished seriously for trout at one place, Penton Hook. That fine combination of stream and pool took my fancy mightily at the first sight, and whenever I have wanted a day of solid spinning for trout I have been to the Hook. It is a water which, from the bank, needs long casting. Once, in May, I found two fish furiously feeding on the shallow below the weir. 
On that occasion I had a light grilsc-rod and was trying the fly. The fish were quite close together, they fed for an hour or more (probably on minnows, for they hardly moved a yard), and I nearly broke my back trying to get out the extra five yards of line that would just have plaeed the Silver Grey under their notice. I failed.

On another occasion I had better luck up to a point. At about sunset a big trout showed at the other end of the Hook, in the deep water off the sill of the overflow weir. He was well out in the river, and it was a long cast for a light bait. However, for once in a way I did what I wanted, and dropped the bleak almost exactly in the swirl. And then I began to pull it home as steadily as I could. At onee it was plain that things were stirring. For neek and neck with my revolving bleak raced another bleak with hops and skips, going hell for leather, while bchind both eame a tidy wave. My heart rose into my mouth. Which was the trout going to take? The race lasted to within a yard or two of the bank, and then of eourse I knew and sorrowed. While it lasted it was as exciting an experience as I have ever had in fishing. Even now it almost makes Thames trout fishing seem worth while.

There are some other livers where spinning in the 'Thames fashion with relatively strong tackle and big bait pays, but in general the business is more 
delicate. On the mountain streams it can be a very pretty art. On a coldish day with a ruffle of wind, even though the water be rather low, a small natural minnow mounted on some inconspicuous flight and very fine gut may do great execution and account for big fish. I have found it best as a rule to fish upstream. Though the bait has to be spun home more quickly, I think the fish take it better. It is more difficult to handle rod and line in upstream fishing, but that $I$ take to be an advantage. Personally, I always cast from the coil for this purpose, never having had a reel with which I could throw a very light bait accurately enough for short casts, often among bushes. But with two or three coils on the left hand one can do all that is needed. For downstream fishing, where one can use more lead and make longer casts, I rather prefer casting from the reel. It is less trouble, and I think the steady spin of the bait is more attractive to trout.

On the whole I have found the natural bait do better than an artificial, though its superiority has not been very marked. It certainly induces bolder runs, as might be expected, but it does not necessarily move more fish. I remember a day on a small liver, where the water was rather full and slightly stained, and the weather rather blustery. I fished with a small gold Devon for several hours, and I should think I must have moved every considerable 
trout that saw it over two miles or more of water. I had a most optimistic report of half-pounders, and better, to make in the evening. But I was not able to produce any in proof, for of all the good fish that followed or came up at my minnow I did not land one. One or two were just prieked, and that was all. If I had had any real minnows I might not have secn so many trout, but I am pretty sure I should not have had quite a blank.

Mountain trout take an artificial minnow better when the water is decidedly coloured. A gold minnow in a porter-water is sometimes extremely effective. And, where it is allowed, it may be very uscful then, because as a rule the porter-water means that there has been a yellow flood, and that the trout, gorged with worms, are indifferent to flies. The bright little spinning bait stirs them up.

Fancy in types of bait must be largely determined by accident. I happen to have done best with the Devon minnow in one of its forms, so I depend on it more than on anything else. I do not remember ever killing a trout on a Phantom, though I know quite well that some men find it all that they need. And on the other hand I have never killed a salmon on a Devon, though I have done pretty well with the Phantom. Which shows how oddly things may turn out for the individual. Probably the reason in my case is that $I$ do not find a Phantom revolve 
so quickly as I could wish for trout, while in salmon fishing I find a big Devon too heavy and too fond of the bottom. So as a result my use of the baits is strictly limited. At one time I was very fond of some Devons made of clear quill, and I found them quite killing among some trout that knew a deal about the ways of the world. The trouble with those minnows was that they were rather fragile and were apt to lose their metal fans. If quill minnows could be made all in one piece, with quill fans, I think they would be excellent. ${ }^{1}$ The Wagtail is rather good for big trout and so, sometimes, is the spoon. But it would be hard to find any wellmade artificial bait which would not do execution, and I should be about equally hopeful with anything, having, however, first regretted that it was not a natural bait.

In an earlier chapter I touched on the dropminnow, an art which is closely allied to spinning, though it is different in essential points. I then extolled its merits for fishing small overgrown brooks, and there is really not much more to say about it, except that it is extremely deadly in other waters too. On some of the Border rivers they know all about the drop-minnow, and many is the fine trout

1 The pretty eelluloid minnows made by the Dreadnought Casting Reel Company, Newport, Isle of Wight, to a great extent meet this need. I have found them good for both trout and pike in clear water. 
that with its aid is cozened out of the deep, still pools even in time of drought. One sometimes sees complaints, especially from the West Country, that streams are being spoilt by too great a survival of old cannibal trout, the big-headed fish of some two pounds which possibly do more harm in a water than good. ${ }^{1}$ Occasionally these complaints result in a crusade against the cannibals with nets. I believe that a carcful use of the drop-minnow in the pools when they are low would matcrially reduce the number of such fish, and it would be a simpler job than an elaborate netting.

There is one other use of the minnow of which I was told one autumn when I was salmon fishing a Border river. I have never seen it practised, but it was described to me as bcing extremely deadly. It consists simply in legering with a dead minnow in an eddy when there is a yellow flood on. There is a bullet on the line about two fect from the hook, the minnow is attached to the hook, and the rod rests on a forked stick such as roach fishers usc. The "deid minnow," as it is called, seems to be the local stand-by in certain districts in circumstances where other districts would favour the worm. I

1 Sinec this was written, Dr. Knut Dahl has published in the Salmon and Trout Magazine his very interesting experiments with trout ova. Put succinctly the results are : big parents, big ova, big and quickly growing offspring. I think our attitude towards the alleged cannibals needs reconsidering. 
suppose the line is so arranged that the minnow wavers to and fro in the stream, but it may be that trout in some circumstances will take a bait which is frankly dead and without movement at all. I have heard of their being caught on a quite dead minnow suspended below a float. But I must own to a prejudice in favour of some attempt to simulate life in one's bait in whatever way it is employed.

I have touched on the worm in relation to trout before in this book, but $I$ hope that my readers will not impute to me too great a fondness for the subject because I return to it. As a matter of fact, I am not over and above fond of worm fishing for trout. And yet memories stir in me which forbid my saying that I do not like it at all. One of my carliest experiences of trout of any magnitude was gained on some extremely pretty ponds which run in a kind of chain down a Worcestershire hill, the two or three at the bottom forming a feature of a delightful garden. I forgot how I came to be fishing them, but I think I must have asked for permission in an extremely brazen manner. It was, I am sorry to say, a custom of mine as a small boy to apply for fishing leave without any respect for persons or places. Nor do I remember ever getting "No" for an answer. The long-suffering displayed by grownups to small fishing boys is marvellous. 
Anyhow there I was on the lawn with a stiff rod in my hand, a float before my eyes, and a worm somewhere under the water. I remember that the float had been dropped in quite close to the campsheathing which fortified the hatch between the two ponds. I knew a lot about perch in those days, though little about trout (and nothing about trout in ponds), and I picked for my first venture a spot which perch would naturally choose in the hope that trout would not be far different in habit. The float disappeared with very little delay-I still retain the freshness of the incredulity with which I saw it sink-and after very little more delay I possessed a large trout. I think he was three-quarters of a pound. I certainly wasted no time in playing him.

The rest of that day is less vividly before me, but I remember that it did not go on as it began, and that I did not make a huge basket of fish. I got three only, one I think about a pound, the other a fat creature of six ounces which was the most beautiful object I had ever seen, as golden as a new sovereign. That fish came from the top pond of all, a mere puddle up in the wood, which must have been above the fishery proper. Very handsome treatment in the matter of Iuncheon, and a seven-mile walk home in the evening are my other memories of the day. 
There is a curious circumstance about those ponds. I fished them once again, and once only, so far as I can remember, and then with the fly, which I had studied assiduously in the interval of, I think, a year. I know I had a fine catch then, and I am pretty sure it consisted of eleven fish averaging probably three-quarters of a pound. I know also that I was intensely proud of them. Now I sometimes meet the present owner of the estate, and he always assures me positively that the effect of me on the fishery was as the effect of a net, followed by a draining dry, with a dressing of lime to wind up. The cataclysm, such as it was, occurred before his day, and I suspect a twinkle in his eye. But obviously I somehow gained a great and terrible reputation, and the only conclusion I can come to is that I must have talked at large and multiplied that catch by at least ten. Small boys do that sort of thing when exchanging notes. If you listen to them comparing their fathers you are pretty sure to hear one, in the crescendo of effort, make some such claim as that " $M y$ father can hold six lions in each hand." And I fear it has not been otherwise with any of us.

I have seen some big trout caught with a worm in my time, especially trout of the type found in rivers which are mostly stocked with coarse fish. I remember a brace weighing over five pounds 
and over six pounds respectively being caught within half an hour of each other from identically the same spot in the corner of a small weirpool. One man would doubtless have had the two, but after catching the five-pounder he naturally thought that honour was satisficd and that he might go off to lunch. By which the next comer benefited. A curious feature connected with that incident is that never another really big trout was taken from that pool with the worm, though one or two were had afterwards by spinning, and one or two, I believe, with the fly.

On another fishery I can remember the capture of heavy trout with worm, generally by a method ludierous in its straightforwardness. The honest angler marked his big trout down where it lay on some gravel pateh near the bank. Then he went and drove it away. This done, he placed a fat lobworm on a hook just where the fish's nose had been, let out some line, and afterwards retired into the meadow with his rod. When he had waited a reasonable time the fish came back, found the worm, and the drama was played to its conclusion. I am afraid there is not such a store of great trout in that water now as there was then, but even if there were employment of the old device would seareely be possible. A female olive, or a malc black gnat, or some such deviee, is the gencral rule in these days, 
though it does not succeed so well with the sixpounders, of which there must be some left.

I have never caught a really big trout with the worm myself, but I have had occasional threepounders when perch fishing. I remember travelling down for a day with the Kennet perch in October, and being rewarded with but a solitary bite, from a trout of over three pounds, and a similar thing has happened to me more than once. People who only fish for trout do not know the experience of returning three-pounders with revilings. I would much sooner not get a bite at all than be tantalised in that way. This brings me to a point on which I want to touch. The large trout has, except in waters which are much fished in that way, a disconcertingly wholesale method of dealing with a worm. He just swallows it. If you want to return him the only thing to do is to cut the gut off as short as possible and let him go. If you injure him by trying to disgorge the hook he dies. I think a trout dies if he bleeds at all on being unhooked. The only safeguard that I know is never to use a single hook in coarse fishing where there are trout. Use two hooks, Pennell fashion, about two or two and a half inches apart, and strike as soon as you get a bite. Then you will almost always hook any fish in the mouth and there will be no swallowing. It is a decided advantage for perch as well as trout. 
In waters where the trout know quite well that the arrival of a worm on a hook means that they are being fished for they will often niggle with it as daintily as a roach with a piece of paste, but now-adays such waters are growing less numerous, as the worm-fishing fraternity either dies out or becomes converted to the fly. So the danger of a trout's swallowing everything at a gulp is generally considerable, and that is why the worm does not appeal to me except in special circumstances. It makes fishing altogether too crude a business, and shows a noble fish up in such a bad light as the worst kind of glutton. It is preferable to ignore this side of his character, and when possible to appeal with fur and feather to that better self which he also undoubtedly possesses.

But as I have said, there are special circumstances. There is the little overgrown brook which you cannot fish with a fly. Its case I have considered earlier. Then there is the pea-soup flood on the mountain river. This is a kind of fishing which every one unites to condemn in the loudest tones. I condemn it too at the top of my voice. And yet, and yet-there is a kind of fascination about the thrill that comes up the line when you have let down your worm into the yellow eddy or slack to find a trout ready for it at once. Very occasionally I must confess to enjoying an hour with the worm in 
a spate. But I do not care to go on long at it or to try for a big catch. Three or four fish, just to recapture old thrills, and $I$ am done with it.

It is otherwise on the tiny burn which you fish upwards, moving from pool to pool. There I will take my full day with gratitude. The worming I mean is in the bigger river, where you can take a dozen fish from a single lay-by if you give your mind to it. When you know that in a day or two you would be able to catch those same fish or their likes with a fly worming in a flood scems a poor game after a bit. It is one of those things which have deteriorated with the lapse of years. There is no such worming now as there was on that wet morning when I found that the free watcr at Rhayader, far from being destitute of trout as I had supposed, was replete with great fish. How they rushed for the worm! And how they fell back one by one into the turbid stream with resounding splashes! I am sure I lost twenty pounds of trout that morning, little fool that I was. That roas worming if you like, and such sensations will never come to me again.

The clear-water worm by fairly common consent (exceptis excipientibus!) should be placed in a different category, and it represents an art of fairly high order. It calls for many of the qualities required by the fly fisher, as an eye for watcr, a scnsitive 
hand, and so on. And it demands great expertness in the use of rod and line. The clear-water wormer must be able to pitch his bait into a tea cup, as the saying is, and he must keep in constant touch with it as it travels downstream towards him. But, when all is admitted, I am not particularly fond of the method, and, though I sometimes sct out determined to give it a thorough trial, after catching a few fish I generally find myself getting bored. But here again I differentiate between a river and a burn, and it is the river which bores me, not the burn. Given the conditions of low water and hot weather which make clear-water worming a success, on a river I enjoy myself far more by picking up odd fish under trees and bushes with a dry fly. You don't get so many, but you enjoy the catching of them far more.

Possibly as a clear-water wormer I am hampered by not ycarning for very big catches of trout at any time. When I read in some of the old chronicles, such as Henderson's My Life as an Angler, of creels bursting, poekcts stuffed, and a residue of fish slung on withy twigs, I simply cannot understand the frame of mind which requires satisfaction to brim over in that manner. I am sure Mr. Henderson could not have caten sixty trout, and in the wilds of Northumberland in those days he could hardly have found means of despatehing them to friends. 
He must have "scen red." And so must Mr. Stewart and some others of the great anglers of that time who counted on from fifteen to twenty pounds of trout as a reasonable day's catch.

Possibly some one will wish to say, "Ah, you say you don't want big catches because you cannot make them." And part of that would be true certainly. I do not think I could catch twenty pounds of trout on any Border stream in a day either with worm or fly. But, apart from lack of Border skill, I should be handicapped by not wanting to, unless of course the fish were three pounds apiece or more, when the impulse would be different. After a time I should find myself returning quarterpounders, and if that did not check the run of luck I should return fish of six ounces. A red-letter day seems to me an opportunity for big average weight rather than for a gross total.

Only once do I remember having such a day as the mid-Victorians seemed to consider their due. On that day I consigned to their fate seventy-two trout ranging from about a quarter of a pound to about three-quarters of a pound. I put it in that way because as I caught them the fish were taken away alive in water cans to be placed in the hotel stew. It was on a German stream which, so far as I could learn, had never been properly fished with fly before. It was a great day certainly, and the 
catch must have weighed over twenty pounds, but it did not seem like fishing. It was more like gathering in the harvest. It was on that day that I landed three trout at onee, all over six ounees, and one of them three-quarters of a pound, the only occasion on which I have had such an experience. They got tangled round a bush stranded below a little fall, and the youth who gillied me had to wade in and scoop them out with the net. Which shows you at once that it was not real fishing. Had it been, a German youth entrusted with a landing-net would certainly have knocked them off the hooks one by onc. But Kultur had not really become a live issue in those days, and it was also practically a virgin water. 


\section{CHAPTER IX}

\section{THOUGHTS ON BIG FISH}

A trout is, I take it, a big one according to circumstances. I have seen a man in one watershed with mouth open and eyes a-goggle on a fish of one pound being produced for his inspection. On another watershed I have seen the same man carefully returning a fish of over that weight to the stream with hardly a groan, or anyhow with no more complaint than is permissible to a wet-fly fisher newly introduced to a chalk stream. One's memories of big ones, therefore, must necessarily be coloured by the conditions in which they were caught or seen-in my case more often seen than caught, and I think it is those that were merely seen that have left the most piquant memory behind them.

I remember once taking a country walk with a friend who is now dead. It was just a country walk with no atmosphere of fishing about it. He was no fisherman, and so far as I knew there were no trout within miles. But it was lovely country and hot summer and I was quite happy. About lunch time 
we sought the hospitality of a cottage standing a little back from the road in a clump of trees and there procured a simple meal. It proved to be one of the lodges of some big estate, and after eating we trespassed a little, because I had seen the glint of water through the trees and I can never resist looking at water. It proved to be the narrow end of a large lake, and there on its bank we sat us down to smoke and digest for a little before going on our way.

Presently we became aware of several large fish which sailed lazily in and out of a sort of weedrack or grating which crossed the water. "What are those?" asked my friend. "Carp," I said promptly, for they were too big to be anything else, though they were too far off to be clearly distinguished. Presently, however, their wanderings gradually brought them nearer, and to my astonishment I perceived that if they were carp they had miraculously acquired adipose fins. Of course they were trout, and they were certainly the most distinguished company for average size that I have ever seen in my life. The smallest must have been over three pounds and the biggest may well have been six or seven pounds. I suppose there were eight or ten of them in view. I have often wondered since whether they were a fair sample of the stock in that lake, and speculated what, in 
that case, a day's fishing there would be like. They did not give the impression of being educated fish, and I have always believed that the water would give a sort of record bag. But one cannot tell. I have tried one or two lakes where trout reach a heavy old age almost undisturbed, and found that the patriarchs seem to absorb wisdom without the customary course of instruction, which has been very disappointing to me. Perhaps it is as well that I have never had the chance of being disenchanted on that other water. It can remain a sort of dream fishery with a five-pound average and no reservations, mental or actual.

The biggest trout I ever saw alive and in the water was in the Kennet at Newbury, at the extreme bottom of the Piscatorial Society's stretch which is known as "the Three Fields." It was about 6 a.m. I had come out soon after daybreak with some idea of fishing, but had found the river too low for anything owing to the action of the mills which, I suppose, were holding back water for their day's work. So I sat on the boundary fence and meditated on things in general and on the differing aspects of a river when it is full and when it is nearly empty. I was roused by a splashing a little below, and looking round I perceived a really enormous trout with half its back out of the water rolling about and gathering in minnows by the 


\section{THOUGHTS ON BIG FISH}

mouthful. It was a magnificent fish with decp golden flanks, and it looked fully a yard long, perhaps more. I never dared to say what I really thought at the time as to its weight, but I have always boldly maintained that it could not have been less than fifteen pounds. That would be a modest and retiring estimate for the fish I saw. Later in the same year there was some eonfirmation of the existence of this monster, when an angler who had been trying for the barbel which sometimes lie in a hole a little higher up-or even, in the early weeks of the season, on the shallow itself-returned with a thrilling story of a colossal trout which had taken the worm and smashed his taekle after a furious battle. What was the fish's ultimate fate I know not. I never heard any more of it.

I have seen a few other very big trout in the Kennet, nothing to compare with that one, but fish that might be nearly ten pounds. In most years there are one or two which live elose to the water bridge right in Newbury town, and I have seen a monster or so in other parts of the river. The biggest Thames fish I ever saw was the one in Benson weirpool which I mentioned in the last chapter, a fish of possibly thirteen or fourteen pounds from the splash of him. I remember a huge trout that used to live in the Colne at Uxbridge, which looked like a ten-pounder, but 
it was a black fish and may not have weighed so much as its length suggested. In one or two other rivers I have seen an occasional trout which might be getting on for that weight. One of them, oddly enough, was the Great Ouse, which is as little of a trout stream as any river we possess. It was at Holywell Ferry, and I was drifting quietly downstream in a boat, looking into the water for some signs of those big perch which haunt that part of the river, when my eye lighted on a great fish with spots, an undoubted trout and a big one. I believe there have always been a few trout in the reach below St. Ives, which is much of it gravelly and not very deep, and recently $I$ have seen accounts of some being noticed in the Staunch Pit below St. Ives' lock. Perhaps they are descendants of the fish I saw.

For those who have never seen a really big trout in the water and who yearn to do so, the observation post I could best recommend from my own experience would be the great dam at Blagdon. You may not fish from the dam, but you are allowed to walk along the top of it to get to the lake shore beyond. On a bright, calm day you are very likely to see, with its chin resting on one of the sloping concrete blocks, a trout which will make your heart beat faster. On one occasion I saw two, about forty yards apart, which I am sure were fully 
twelve pounds apiece. One was a light fish, the other a dark one. The next evening I was in a boat and I need hardly say that I made for the dam in the hope of stirring one of the giants. Nor need I say that I might just as well have fished away at Ubley for all the response I got. You can often in calm weather reconstruct big fish at Blagdon from certain signs, the tip of a nose at one point, a back fin behind it and a tail behind that. Sometimes there are appalling distances between these objects as some veteran lazily rolls among the olive midges after sunset. But that is not the same as actually taking in the length and width of the creature at your leisure, as you can from the vantage-point of the dam. Therefore I recommend that promenade for the purpose. Sometimes, of course, one sees nothing there except a threepounder or so, but I am always disappointed if I have passed along without spotting something out of the common.

To the end of one's angling life, I suppose, one will continue at times to be misled by the appearance of things, and of fish among them. Every season I get an occasional disappointment on eatching some trout which, scen at a distance, had struck me as being beyond the common in point of size. But a short time ago I had a rather ignominious experience of the kind. In a tiny stream in which $\mathrm{I}$ 
had acquired angling rights, though circumstances had prevented me from making much use of them, I discovered a red trout lying at the point where the water, from being a system of two or three nothings making damp threads through a meadow, concentrates itself into a single channel and is recognisable as a brook. There is, in fact, a little pool at this point, and in this pool I could see two or three trout, particularly the big red one.

He looked very impressive in so small a place, and I unhesitatingly estimated him at two and a half pounds, which would be a huge fish for the water, whose average weight is more like ten ounces. And I was confirmed in my opinion when after taking my Wickham's fancy he bolted downstream into a clump of rushes, and smashed my cast as if it had been cobweb. Worse than this, I confided my opinion to one or two others who might be interested in the matter, and committed myself to the story that the brook held trout up to two and a half pounds. That sort of story gives a fishery dignity and importance.

I only had one more day's fishing there before the season closed, and then I was unfortunate enough to catch, among others, my red trout, whom I found lying in exactly the same place and on whom I tried forcing tactics as soon as I had hooked him, on a cochybonddu this time. I 
found the foreing tactics unexpectedly suecessful, the reason being clear when the fish came to the spring balance and made no more than one pound five ounces. Seldom have I been worse deceived by a fish; I suppose the confined space in which he had his abode made him seem disproportionately big. Fortunately on the same day I diseovered another trout in a little hateh-hole which enabled me to stick to the "up to two and a half pounds" account. His head and shoulders must have weighed that, though I question whether the rest of him weighed anything. He was a lamentable twenty inches of trout.

I fully expected to catch him when I saw what he was like (though as a matter of fact I did not), for the reason that if there is a decrepit fish anywhere about which only weighs half what it should, it is almost certain to come and take my fly. Possibly my fondness for fishing in odd places, backwaters, earriers, millheads, and the like, lays me open to this, for bad old fish certainly tend to inhabit the quieter and less vigorous parts of a water. Even the well-known monster which lies under a bridge often turns out to be mostly head, and presumably he has some casy nook behind a buttress or in an eddy where he can avoid the exertion of constantly breasting a strong stream. You do not often catch one of these bridge trout, and when you do it 
almost always disappoints you by not coming up to your expectations of its weight.

One of my most grievous disappointments I have related elsewhere. I marked a great trout feeding in a portion of the Kennet and Avon canal, succeeded in getting him to take a dry Wickham, and for several minutes was convinced that I had on the fish of my dry-fly career. He proved indeed to be about twenty-four inches long when at last I got him out, but unfortunately he was one of the old breed which has become dolefully familiar to me, and instead of weighing a good seven pounds as he should have, he only touched four and a half pounds. In the water, of course, he seemed much more than that owing to his great length, and as I was using fine gut the fight was long enough to have been put up by a six or seven-pounder.

As a matter of fact I have only once caught a bigger fish with dry fly, and that was at Blagdon, so it could scarcely claim special honours. It was satisfactory, however, as rewarding a real bit of dry-fly work. I found the fish rising late in the evening in the river at the Butcombe Bay end (the lake was low that summer, so there was a good deal of river in evidence), covered it with a sedge just as if it had been a Kennet fish, and landed it after a real hard fight, four and three-quarter 

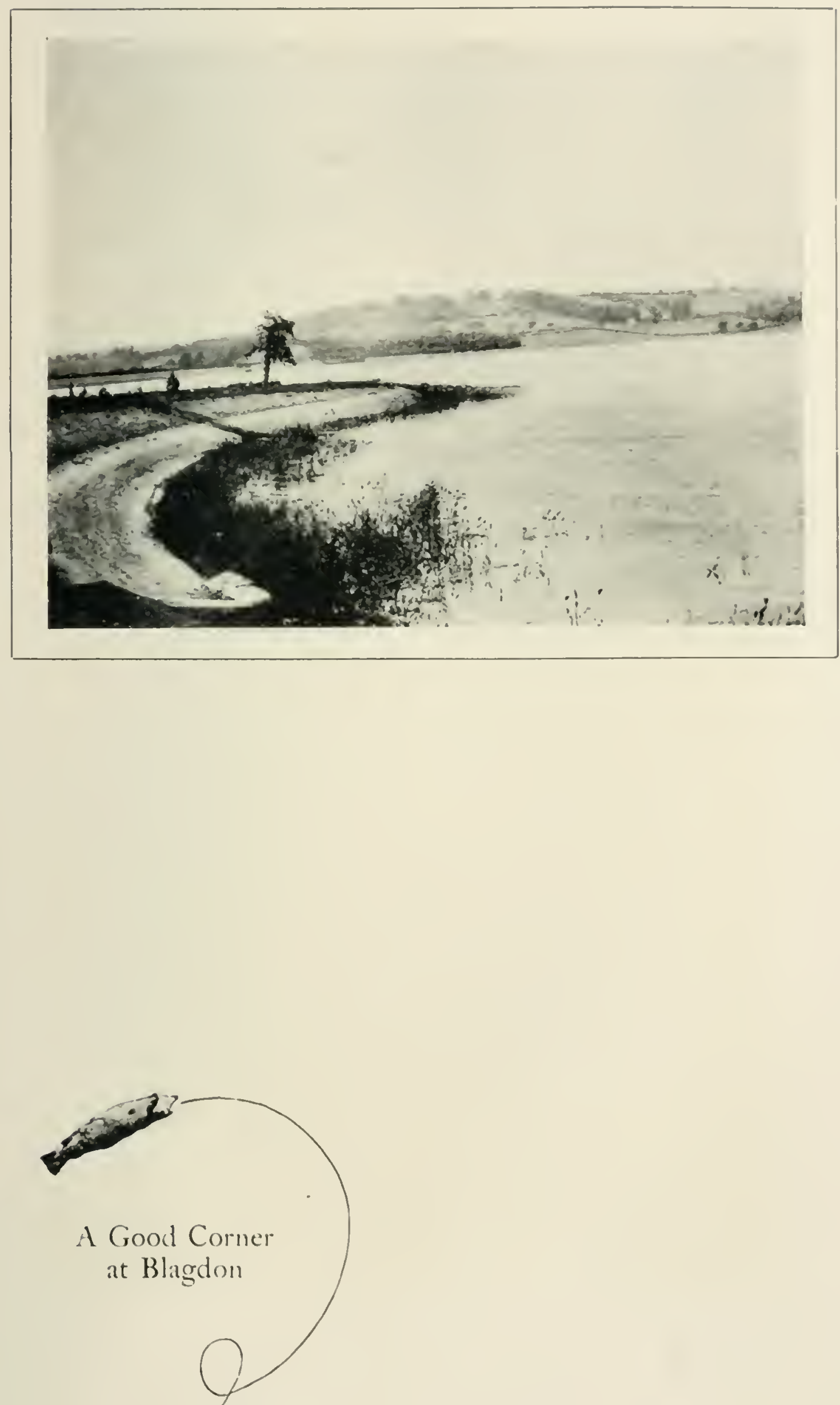

pounds. I remember the eloek striking ten as I lifted it out in my landing-net.

This was a fish of reasonable shape and solidity, but I remember another big Blagdon trout which was less satisfactory. 'This was also caught on a dry fly. It had been found rising steadily just inside a clump of weeds which was within casy casting distanee of the bank. It was feeding in the very deliberate manner which is suggestive of a heavy trout, and when after some time I persuaded it to take a fly-a hackle-fly not unlike the brown silverhorns that were about in plenty-I expeeted something extra special in the way of a battle. The result was surprising. The hooked fish hardly resisted at all, gave a feeble waggle or two, and then allowed itself to be towed ashore. The reason for this was plain then-it was very badly deformed. Though it had the length and framework of a big one, it also had a double spinal curvature, and, as might be expeeted, was anything but athletic, and poorly nourished to boot. The surprising thing was that the fish, a rainbow, had been able, despite physical disabilities which must have attended it from the fry stage, to live and grow to a weight of nearly three pounds.

Rainbows are rather apt to be disappointing on the seales because of their short life and their 
tendency to deteriorate at an age when brown trout would still be putting on ounces. I caught one once at Ravensthorpe Reservoir, the lake which is famous as one of the early proofs of what results can be got from trout culture in water storage lakes, which was rising just like that Blagdon fish, with heavy deliberation suggestive of great size. And it was a big fish, or rather it had been once. It was shaped more like an eel than a trout, and, even so, it weighed two and a half pounds. I have no doubt that in happier days it had been at least twice as heavy.

But, as I have said, it has been my luck to meet with that sort of fish very frequently, so an instance more or less no longer surprises me. I could wish that I was less favoured with regard to big ones of that type.

I do not remember ever hooking and losing the sort of trout that makes history, or at any rate the sort of trout that I honestly believed would have made history. I am not exempt, of course, from the common fisherman's failing of estimating "the big one that got away" on a perhaps too generous scale. The biggest trout that I ever hooked, of which I am certain, I was fortunate enough to land. It came from the famous weirpool at Uxbridge and weighed two ounces under eight pounds. It took a dilapidated metal spinning bait of the Devon 
type and gave me a great fight. I had at that time never scen a trout out of the water of anything like such a size, and I had no idea what it would weigh. Five pounds was as much as I dared to hope for, so my pride and joy when the scales at the keeper's cottage revealed the truth can be imagincd. It was a beautiful fish twenty-five inches long and with decp, gleaming flanks, a picture of an old Colne trout. I had other good and handsome fish from that pool and the stream below afterwards, but nothing to approach that one. The biggest was four and a half pounds. Another angler a few years later got one of seven and a quarter pounds. The Colne has in its time yielded a good many fish of about that size, but I am afraid that some parts of it have now seen their best days. The cxtraordinary catehes at West Drayton made during the years when the water was heavily stocked with big fish, suggest that the river may yet be capable of recovery. The fish seem to thrive well enough in its lower reaches, though of course the Thorney Weir records are not due to the natural breeding capacitics of the stream.

I should not like to assert positively that I ever hooked anything bigger than the second trout on my list either. This weighed six and three-quarter pounds, and was caught at Blagdon on a goldbodied fly which has since done a good deal of 
execution on the lake, and which Donald Carr, I believe, christened "The Field." It is really not much more than an elaboration of the Wickham by the addition of a topping and a red tail; but it is a very killing pattern for big trout of minnowing propensities. Such a fish on my first day at Blagdon made me very pleased with myself, especially as it was companioned in my bag by two others of four pounds ten ounces and three pounds eight ounces. Another man got one of nearly the same weight on that day, and it was an extraordinary circumstance that there was not another trout over six pounds caught for some years. The eight and ninepounders, average weights of five pounds or more, and other portents that made Blagdon so famous all belonged to the two seasons before my first visit.

Afterwards the weight of the fish caught fell considerably, though latterly it has been going up again. The big ones were still there-as I said earlier, I have seen some of them-but for some obscure reason nobody caught any for several seasons. There were tragic losses each year though, and it may have been simply luck. One reason why fish used to be lost there at first was the fact that so many men visited the lake with ordinary trout tackle, the sort of gear which would be well enough for waters where the fish run up to a pound 
and a half or so, but which was no good for a six-pounder which behaved like a torpedo. Gut should be strong for such a fish, and there should be plenty of backing on the reel.

When I get down to lesser weights I can point proudly to considerable losses. The worst certainly was that of a trout which I hooked on a dry fly in a small tributary of the Kennet. I am sure that trout was over five pounds and he would have been the most valued of all my trophies. I had him on for a full quarter of an hour, most of which he spent in a thick clump of sedges right at my feet. He had run a good long way downstream after being hooked, and then turned into the sedges and burrowed well in before I realised what he was doing. I tried every conceivable method of getting him out, and finally endeavoured to tail him-by wetting my arm almost to the shoulder I could just manage to get a hold on him. But, alas! the tail of a trout is not as that of a salmon, and he slipped through my grasp, broke the gut, and was gone. I can remember sitting on a gate for half an hour after that wondering whether I should drown myself immediately or take the next train baek to London, for I knew that I should never have another chance with that trout, and I never did. In carlier days there had been a hatch of Mayfly on that little stream, and then it was possible to look forward 
hopefully. There was a fish of just under four pounds which I had lost three times in one season, and finally killed on a Mayfly. But to find a fivepounder taking small flies on a second occasion was beyond expectation, for such fish are very incurious about small flies as a rule.

I once had a Mayfly day on the Kennet which must have totalled up a large number of lost pounds. It seemed to my excited imagination that I hooked all the biggest trout in the fishery one after the other. They varied from four pounds to six pounds. I do not think there was anything over six pounds though $I$ was quite in the vein to have lost Big Ben himself had I been able to find him. Big Ben was a local institution, said to weigh fifteen pounds but he never gladdened my eyes or subsequently filled my heart with sorrow. His smaller brethren did their best, however, and I was quite sufficiently desperate at the day's end with a paltry brace just over the limit of a pound and a half in my basket and a long list of defeats in my mind.

Sedge fishing has provided most of us with experience of trout which were presumably of unusual size, but it is not at all easy to be certain even in one's own mind. I well remember a tremendous battle with a Kennet trout hooked on a sedge when it was nearly dark. That fish took me 
downstream for quite 300 yards and felt like a salmon the whole way. Had I lost him at the end of it I should unhesitatingly have put him down as seven pounds at least. As a matter of fact he weighed three pounds five ounces and proved to have been hooked in one of the ventral fins. For that reason I have never liked to be too positive about trout which have got off after being hooked in the late evening. But I have twice had to do with fish that felt as the Kennet fish, and for a considerable time had me absolutely helpless to stop or turn them on their downward course. One was in the Itchen and the other in the Test, and both made nothing of a powerful rod and strong gut. Both got off before $I$ had a chance of seeing them. I have had one similar contest besides in the Itchen, but that was in daylight, and I was, and am, pretty sure that the fish was a huge grayling; there were known to be several very big ones at the spot where it was hooked.

Exeept in southern waters I have had very little experienee of big trout, and I have never had the luck to eatch anything out of the common on mountain streams or lakes when I have been definitely fishing for trout. I have had a few relatively big ones when salmon fishing. Once I got hold of one of those old stagers for which the Coquet is famous. I thought it was a grilse when it 
fastened at the end of a long line, but after quite a respectable fight, considering the sixteen-foot rod and salmon gut, I pulled in a big brown trout of at least four pounds. Fortunately -it was in October - he was lightly hooked and kicked himself off, so the experience cannot have done him any harm. Had I got him out I should have been tempted to weigh him, and that might not have improved his health so near the spawning time. 


\section{CHAPTER X}

\section{IN A WELSH VALLEY}

To the convinecd trout fisher it is not essential to have a constant succession of red-letter days or to keep up a two-pound average. No one esteems cither benefit more than I, but I can manage to get along quite happily without them, and so can the rest of the little company which assembles year by year on the bank of the small Welsh river, mentioned already more than onee in these pages, which I always eall the Penydwddwr. It is now some years sinee we were all together there-war has upset many a good old custom-but odd members of the party have been there at some time or other since 1914, and now that it is possible to look forward again, great plans are being laid for a united descent upon the well-loved valley.

The Penydwddwr is a typical Welsh trout stream, that is to say a typical upland trout stream. So far as I have visited them I have found very little difference between the mountain streams of any part of the kingdom. Even the variation in the size of the trout which is noticcable is, I think, more 
a matter of a stream's normal development than of any special characteristics. The further a river runs from its rocky beginnings the richer the land through which it winds, and, in consequence, the more bounteous its food-supplies and the fatter its trout. Some of the famous mountain streams, such as the Usk or the Don, have a greater proportion of rich land to their mileage than others which produce smaller trout.

But even some of the barrencst rivers may have their fertile reaches. Nothing, I should say, could well be more suggestive of an eight-to-the-pound average than the top part of the Cumberland Derwent. In a solid week's fishing round about Seathwaite I think I only got one trout which exceeded six ounces. That was some twenty years ago, but I do not suppose that conditions have altered since then. Lower down, however, it is a very different story. One day below Cockermouth a few years back I got a dozen trout which averaged half a pound, and I heard of a catch of a dozen or more which averaged over one pound. The lower Derwent is naturally rich in fly and on the day recorded I saw the biggest hatch of iron blues that has ever gladdened my eyes. Of course I had no such thing as an iron blue in my fly-book, and I had to make shift with the darkest hackle-fly I could find. It served fairly well, but if I had had some real iron 
blues I might have caught some bigger fish and more of them. I never saw trout rise with more enthusiasm for an hour or so.

I have not had enough opportunities to be didactic about it, but I fancy that wet-fly streams, and parts of them, could be divided into about three classes so far as the size of fish is concerned: (a) The very barren, rocky streams and parts where seven or eight fish would be needed to weigh a pound and where the exceptional half-pounders have big heads and long lean bodies. (b) The normal streams and parts where a five to the pound average is to be expected. Here the half-pounder is better shaped and looks less of a cannibal. (c) 'The rich streams and parts where the average goes up to three to the pound, and where you may expect a sprinkling of pounders, and may hope for an occasional fish of two pounds or even more.

The Penydwddwr, where I know it, belongs to the normal class, and it is not so lavish of its halfpounders as to make us blasé in regard to them. We have, in fact, in that valley a very proper respeet for a half-pounder. Indeed, the word " respeet" is scareely adequate. You really ought to hear Caradoe tell the story which takes him cast by cast to the very top of the run below the bluff, and which ends with two leaps, one despair, and the words " a real big fish, my dear fellow, half a pound." 
Having heard this, you will understand how it is with us, with Caradoc, with the schoolmaster, with the ornithologist, with the angler to whom I must make only the most distant reference, and with me. And those others, the estimable folk who inhabit the same inn with us, also appreciate a half-pounder. They know how long and broad and deep and thick he feels when you lay an eager hand on him in the meshes of the landing-net. Persons who only fish in chalk streams have no inkling of the merits of half-pounders. "Just not sizeable" is a poor way in which to spcak of fishes which make Caradoc arise early in the morning, pedagogues forget the Greek for "strike," bird-men accept a statement that a cuckoo in winter turns into a hawk. All which strange things I have, so to speak, watched happening.

One spring we had a drought and then it was lamentable but true that half-pounders did not happen at all, not the real, unquestionable, eightounce-to-the-half-pound creatures which alone pass the severe inspection of Ap Evan. I did all that I could in the way of asseveration for a seven-ounce specimen brought back one evening by the rod fourth on my list. If that were not a half-pounder, then might I never behold half-pounders moreand so on. But it was all no use. Seven ounces 
were all that Ap Evan and the scales would concede when it came to the ultimate test.

We had, for sheer self-respect, to fall back on the classification method, invented I belicve by the bird-man in one of his inspired moments. By that device you really can catch some half-pounders in the Penydwddwr, and it is an ill day on which you do not have at least one. It is quite a scicntific plan of grouping your fish into growth-classes rather than labelling each one with pedantic minuteness. You find something like it in Blue Books. By this method "half-pounder" is a group term inclusive of all grades of fish from six and a quarter ounces to cight ounces. The next group contains "big fish," which may vary from four and three-quarter ounces to six and a quarter ounces. Then come the quarterpounders, inclusive, of course, of "rising " quarterpounders. Decent fish follow, separated by some little margin from "breakfast" fish. And lastly the bird-man rose superior to the droughts and dearth of that hard time with "visible" fish. It was a handy new group and generally approved.

The river was lower than it possibly could be when we got there and it went on dwindling for a solid week. Daily we went out with less hope of doing anything, and daily we came in justified of our expectations. Even "visible" fish were loth 
to rise, while all others became events. "Did you do anything on the long flat?" one would ask. To which another would reply, "Yes, I had quite a brisk bit of sport there. Got two breakfast fish, and lost a real big one, a quarter-pounder at least." The "big one which got away" was, I think, unusually prominent that year. He afflicted me personally to a grievous extent.

Perhaps the worst experience was with the detestable button on the sleeve of Caradoc's mackintosh. It was on the last day of all, when we really had had a nice drop of rain and the river was in grand order. In quite a short time during the morning I had accumulated five handsome fish, of which two were half-pounders by the class test. But then trouble began, for the wind uprose and beat the rain on my glasses, no fish stirred, I lost half a cast and both the flies, and generally things went wrong. Just as I was getting desperate I hooked a fine trout, and my spirits went up with a bound. He played fast and far, but I was his master. 'That trout, half-pounder though he might be, was as good as in the basket. I felt with unhurried left hand for the net in the sling, meanwhile drawing the trout downstream. And then the button on the sleeve saw fit to catch in the meshes of the net, and in a flash my mastery was gone. Not only could I not get the net out; I could not 
even free my left hand. So in due course the trout kicked himself off, leaving me alone with the wind and the rain and the conviction that all was over. I do not wish to blame Caradoc in any way - after all, he had kindly lent me the garment, and that it failed to keep the rain out was not his fault-but I do blame the button. Anglers ought to tie themselves together with tapes or string, not imperil their immortal souls by the use of buttons.

The chub also lost me a fine trout the day before by swinging about my legs and nearly upsetting me at the critical moment. I had better explain the chub. There were nine of them, weighing from about three-quarters of a pound to a pound and a half, and they were the fruits of an amusing hour or so at the pool by the wall. The custom of the river is, I believe, to kill chub in the most violent manner possible, and then to kick them about the landscape, cursing as you kick. Truly chub are not wanted in a small trout stream, but I have an affection for those despised fish, and besides nine of them made a brave show and might be valued by some poor body. So, since they were too big and many for my little ereel, I slung them on a leather bootlace presented to me for other purposes by the sehoolmaster, and slung that to the landingnet sling. An uneommon nuisance they were, eleven or twelve pounds of them a-dangle, and as 
I have said, they nearly upset me when I was playing the best trout of the day. After that I deelined to be burdened with them more, dragged them to the nearest roadway, and there left them, in the hope that the not impossible poor body would find them for himself. I have reason to believe that this happened, for next day the chub were gone. It may have been that the poor body coveted the bootlace. One never knows.

The gravel bed caused us all bad quarters of an hour from time to time that spring. The gravel bed is an inferior sort of fly which appears in vast numbers and makes the trout go half mad-not quite mad-just not so mad as to take any sort of artificial fly. Ap Evan had two counsels for coping with the gravel bed rise. One was to use something else, as a March brown or half stone. The other was to give the affair up as hopcless. My feeling is that he thought more highly of the second plan. Yet people do eateh trout during gravel bed rises; and some deseribe the opportunity afforded by them as a thing not to be missed. All I know is that we made nothing of the business. Some of us evenso it was reported-daneed with rage at seeing so many and so big trout moving without being able to catch them. It was a new experience to see trout moving in numbers in the Penydwddwr. It was a new experience also to see abundance of fly, 
not only gravel bed, but also March browns and the spinners thereof, besides smaller kinds. And it was new also to have warm weather. If only there had been a decent quantity of water! But the water came as our time was practically up. 'Tis ever thus.

I have said that there were no genuine halfpounders. Nor were there, but one evening we were all staggered to behold a trout of some fourteen inches' length which weighed within a trifle of a whole pound. It was a portent, and we stood in a dumb row before it, wondering how such a thing might be. It had been hooked in a fin, moreover, and had kept its captor in play for some ten minutes. You might go to Penydwddwr many times without seeing such another. But you might sec my threeand-a-half-pounder in the big flat if you looked close. I saw him one evening and came home and talked about him at length, not unmindful of the proverb about "having lived near the rose." On the whole, I did well out of the incident. It was unlucky that I should see him again a day or so after. I found that while men slept he had turned into a chub. Pcople laugh casily at Penydwddwr. I had made similar little mistakes there before. I question whether honesty is invariably the best policy. But, on the other hand, had some one clse discovered the truth they would have laughed more. Perhaps honesty stands where it did. 
The most remarkable incident of the expedition was the humour of the bird. It pounced down upon the artificial fly of one of the anglers. That was no uncommon thing. It had happened to me often. But I had never before heard of a fowl with such a sense of fun that, having seized the fly, it would carry it to the top of a tree and leave it there. If any should doubt, we were told that the fly was there yet, and half a cast with it, and that any one might prove the matter by climbing.

Another spring visit to the Penydwddwr Arms was spoilt by an exactly opposite condition of affairs, due, it was supposed, to comets, of which there had been much talk. We had many trials that year. Apart from the weather, we found that the local farmers had had a burst of energy and had been consolidating their fences. We spent a good deal of time extricating ourselves from the traps they had set, and it was a warmly discussed problem why barbed wire was necessary as a lining to trout streams, in some places reinforcing stout hedges and serviceable railings, and whether, as one angler gloomily opined, it had been arranged with one eye on beasts and the other on fishermen.

The Welsh farmer is not invariably sympathetic. Nor are his bulls, of which we discovered an unusual profusion that year. They glowered at us in all sorts of unexpected places. Given plenty of barbed 
wire, a river in half flood and rising, and a bull waiting for you to come out of it, and you have your day's exeitement fully provided.

The sort of wcather we all had can be gauged by the fact that from time to time one of us would rise silently from his chair and step from the sittingroom into the hall. Then would come the sound of hammering - the barometer. Our landlord, easygoing man that he is, even he was moved to protest. He said that the instrument could not be cxpected to do its honest duty when beaten like that. Whereupon Caradoe told him the story of the irate gentleman who threw his expensive but unresponsive barometer into the garden with the remark, "Go and see for yourself, you beast!" Certainly our barometer did very strange things. It elimbed to a giddy height, leaped suddenly down to "mueh rain," and then climbed again just as quickly. Perhaps there ought to be a mark for comets on barometers.

While I was away a dry-fly friend wrote to ask why I was wasting time over "Welsh minnows," a question begotten of a recent vietory over a fivepounder in the Kennet. He would have had his answer had he felt the thrill that I felt on the one satisfactory day when waist-deep in the chub pool I saw that I had hooked, not after all a chub, as I feared, but a veritable trout of great size. He 
weighed half a pound, a real half pound, and the joy that seized me when I saw him, to be followed by immediate quaking lest he might get off, was certainly no less than that which was mine at Mayfly time when a supposed chub proved to be a noble Kennet trout of three and a half pounds. In the evening I got another half-pounder in the same pool, and the brace will live long in my memory, if only for the effectual manner in which they enabled me to answer Caradoc, who also had one, and was prematurely jubilant over it.

One day, rendered despcrate by the weather, I angled with worm in a flood and tore out several unfortunate trout by brute force. Time was when I thought worming in pea-soup eddies the height of bliss, and I was curious to see if the glamour of youth could be recaptured. There is a moment -I have before confessed it-when you live at this business, the moment in which you feel the first twitch at the line as a trout essays the worm. Nor will I deny that the four quarter-pounders which I got out of the little channel below the mill-wheel gave me pleasure, nor that, as the six ounce fish fell back, I lived once more some of the old agony. These things I confess. But there came a moment when I was conscious of blood and slime, and that I was engaged on a very black venture. And, moreover, I had no half-pounder. So I put away 
worms and fished to no purpose with a Devon minnow. We had that day a hailstorm which gave me a cold. It was ineredibly fieree and ehilled me to the marrow, so that I had to go home to get early tea and warmth.

On the last day of that visit I had a useful lesson in humility. The "local expert" had always appeared to me an overrated person. In London I had ventured to state in conversation that he was not likely to be much more successful than any visitor of reasonable skill. I had to retract all that. I toiled exceedingly all that cold day, struggled with an abominable wind, fished, methought, very well considering, and returned at tea time with eleven fish, convinced that all that man could do in the way of tempting sulky trout had been done by me and that my basket represented the limit of possibility. But I found that Ap Evan had been out and between about half-past one and four had captured some two dozen very nice fish, all with the March brown, a fly which had caught me nothing at all. The fact is that local experts are very fine fellows; we visitors are nought.

The biggest fish I caught at all was, oddly cnough, a dace of nine ounces, a fish which, so far as I could learn, had never been eaught there before, though chub are fairly plentiful. I saw it rise at the tail of a long flat, and put my tail fly over it dry. 'The 
disappointment of finding that it was not a good trout was somewhat mitigated by the interest of its identity. I think it was envy which made certain persons asseverate that it was a chub, in defiance of all the indications of shape and fins. The oddest experience I had was being spectator of an affray between a sparrowhawk and two thrushes. I was knee-deep in a quiet pool when I suddenly became aware of a commotion in the hedge that bordered the water on the left bank, of great fluttering, outcry, and flying of feathers, all not five yards from me. It proved that the hawk was attacking a thrush, probably on its nest. Then the thrush's mate arrived in a hurry, and some further battle ended with one bird's flying away with the hawk in pursuit and the other's vanishing, perhaps following on the other side of the hedge. I hope the hawk got defeated, but events passed beyond my ken.

The most vivid realisation of Penydwddwr as a place unspoilt and good to bc in perhaps came when I conversed with the friendly policeman. Comets and aeroplanes were the topics, and then he told me about the balloon. It passed over the district one misty day, to the unqualified terror of the inhabitants, who had never seen or heard of such a thing. Flying low, it almost grazed the hill beyond the river, and a lonely shepherd caught sight of a rope hanging from the miraculous bird or whatever 
it might be. This, running, he vainly tried to seize and fell flat. And as he fell to his horrified amaze he heard mocking laughter from the skies. Wonder was not dead then, though even at Penydwddwr they must now be used to men who travel with the elouds.

The last visit I paid to Penydwddwr was shortly before the war, and it was at an unaceustomed time of year. The fact was that I had heard of salmon there if one was on the spot during August floods, and it struck me that a salmon or two a day from those little pools would be very pleasant amusement. So it would be if it ever happened, but so far as I could judge it does not happen.

Caradoc, who exhibited symptoms of jealousy when he heard I was going, said, "I told you so," as soon as I had returned. For I had to confess that the expedition, from the point of view which regards heaps of slain fishes as the summum bonum, had not been a complete success. Not that I would impute such a point of view to Caradoc. In the spring we do not pile our fishes in heaps. We say that we do not like our fishes so, that a few trout, and those good ones, are what we prefer. And we get the few trout all right, while as to goodness I never met any that were better on a breakfast table. There are, be it noted, different kinds of goodness which trout may have. An ability to streteh head and 
tail beyond a dish does not exhaust the cardinal virtues.

Accustomed to the Penydwddwr of spring, I was astonished and saddened at the stream which greeted our eyes on arrival. The Colonial, who was one of my companions and who has since eschewed my company on fishing holidays, was of opinion that it would be rather like the thing called "a creek," only the creeks where he came from had water in them which ran along. (I shall never get quite reconciled to the notion of Greater Britain that a creek is a small stream, a burn or beck; to me the word always suggests a convenient ditch by the Thames into which you can run your punt.) Closer inspection showed us that the Penydwddwr was moving along, for " even the weariest river winds somewhere safe to sea," but it was patent that the fishing would be nought until what the third member of the party called the "grcat rains" should come. As for the fourtecn-foot and sixteen-foot rods which formed part of my armament, they were as out of place by the attenuated stream as a racing eight would have been upon it. I took them, blushing, and hid them in a corner.

Then we composed ourselves to await the great rains. There were kingfishers, herons, and other birds to be seen daily on the stream. In the little wood behind the garden were three brown owls, 

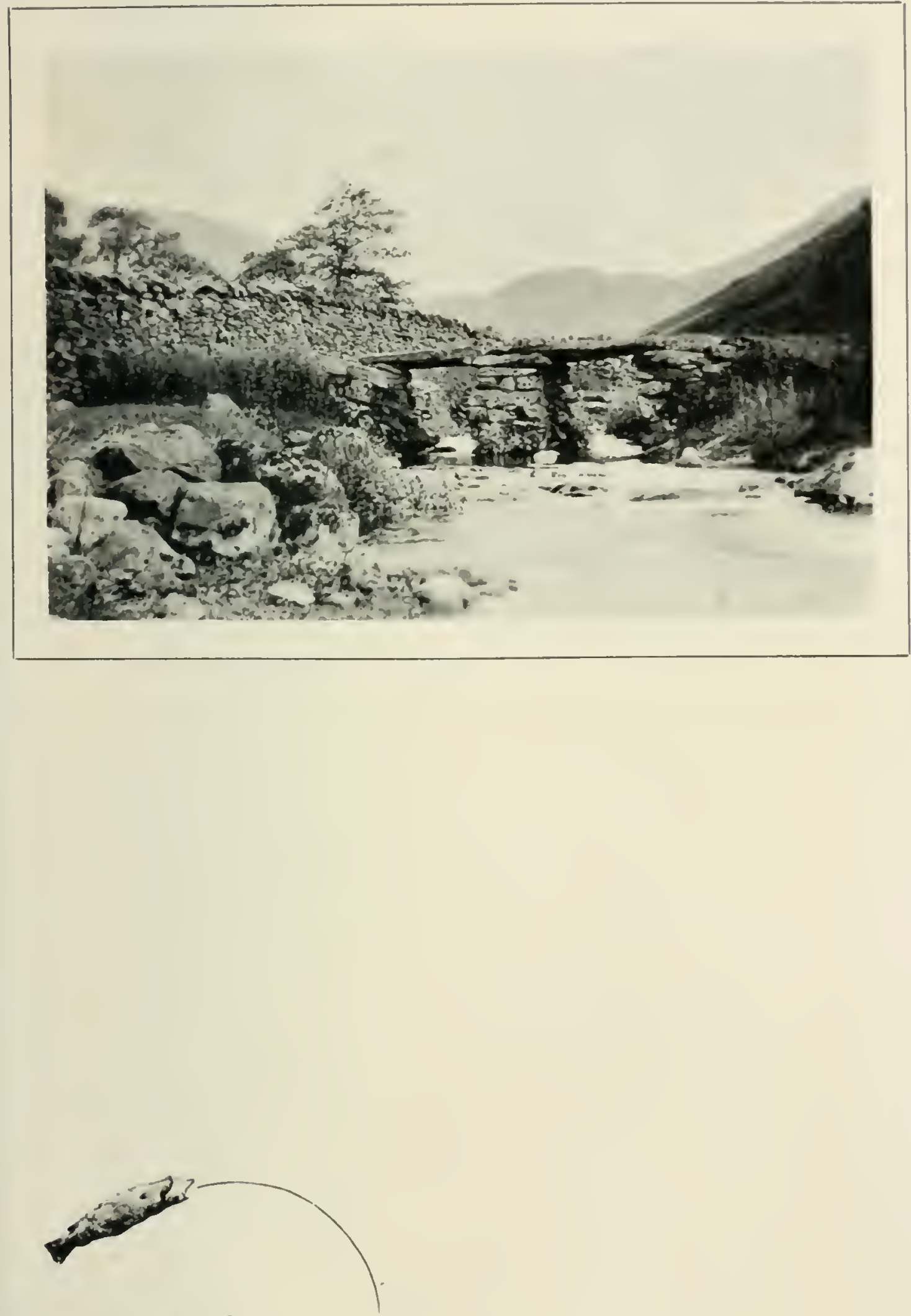

A place for

"Breakfast" Fish 



\section{IN A WELSII VALLEY}

of which we could generally obtain a vicw by going cautiously to look for them. 'Their large round eyes would look down at us reproachfully from the upper branches, and their large round bodies would sooner or later remove noisily to a less visible perch. I got the impression that, nocturnal though they be, brown owls ean see quite well enough in the day time to scrve all their necessities.

In the roadway before the inn door commonly strutted an important turkey cock. I was privileged to behold this bird in two sets of circumstances of delightful contrast. A little lady emerged from the inn one day. She wore a red tie, but had about her no other sign of fierceness or offence. Suddenly across the road came a resonant gobble, and the big bird came purposefully from the farmyard, giving his opinion as he came. "What a funny bird," was the amused greeting he received, as he stalked majestically on. Amusement, however, gave place to hesitation, for he came closer and closer, and his gobbling waxed louder and louder. And the next thing was a vision of flying skirts - the red tie and its wearer were gone, and the turkey was alone in his glory.

On the other occasion from out the door came not a lady, but an cight-wecks-old black spanicl puppy. This waddling atom saw the dignified bird but two yards away. 'To see was to act, and we had the o 
inestimable privilegc of beholding a turkey hunt conducted by a pack of one. Nothing could have been more ludicrous than the ignominious flight of so large a bird before so small and round a pursuer.

Besides birds there was a rich vegetable world to study. Development seemed to be a month later than in the south, and the meadows were rich with hay and with some of the flowers which had greeted me in Hampshire in June. The lanes winding upward to the moors contained quite a store of wild strawberries, which gave us an agreeable kind of mild hunting, and here and there were wild raspberries of excellent flavour. Of an evening, too, there was occasionally an Eisteddfod to which one listened out of the window. Several really beautiful voices well maintained the reputation of Wales for folk music.

This, of course, is not fishing, but I am not sure whether our actual efforts with the rod were much better deserving of the name. We frankly pottered, limiting our ambitions to getting enough trout for breakfast, and occasionally making a raid on the chub. Here I have an observation on gratitude to make. It had struck me that the Colonial was getting "kind of homesick." He did not consider the Penydwddwr a real creek-in real creeks you can, it appears, catch brook trout in dozens on No. 6 flies, and you take them home on a string-and his 
baskets had been light. "What you must do," I said, "is to have a go for the chub." "What are chub?" he asked without enthusiasm. "Chub are___" I hesitated for a comparison_- "I know. Chub are just like squaw fish."

His eye brightened. The good old squaw fishit was like a message from home, though, I have gathered from his conversation, at home the squaw fish is not cxactly a prized trophy, but contrariwise. Anyhow, I had rekindled hope in his breast, and he had a go for the chub.

That evening I returned to find that he had captured a really considerable chub, a fish of nearly threc pounds, which is big for the Penydwddwr. Was he pleased? He was not. He thought meanly of the chub. He spoke meanly of it. He regarded the escape of just such another not as a misfortune, but as an incident of no importance. Didn't they fight? No, not worth naming. Weren't they like squaw fish? No-gloomily-squaw fish had tecth. And he was not a bit impressed by the chub's throat tecth, as described. Altogether the matter turned out disappointingly, and it was not long after when the Colonial "hit the ties," "boarded the cars," or whatever Greater Britain ealls going by train, and went off to London to sce about some "real estate," or "preemptions," or "town lots," or something. Nor did he return. 
Meanwhile I went on waiting for the great rains. Not a drop was granted to us, though clouds appeared promisingly on several occasions, and though onee we even heard the rumble of thunder in the hills. For the most part we had blazing, windless days, and it was only by dry fly in shady corners or by drop-minnow in the deeps that I could extract a few trout while the light was strong. Now and then I went out, and caught breakfast between dusk and dark, a dragging of big flies which involves little skill and some alarms. The riverside at night is an unfamiliar place, full of queer shapes and uncanny noises. On the whole I did not do so badly considering. Though the trout were few, and to be counted by the brace rather than by the dozen, they ran to a better size than they do in spring. Then I have found the average size on a decent day to be under four ounces. On this last visit the trout I caught averaged between five and six ounces, and a fair proportion nearly or quite reached the half pound. Moreover, there were the chub, of which I took toll daily, and with which I had plenty of fun. Chub in a low, clear mountain stream require a lot of stalking, and the sport was not to be despised.

There was also one salmon which took a shrimp, and a few other salmon which would not take anything. Only the first deserves more than passing 
notice, and he, not because he was caught, but because he took at all. He was lying in less than four fect of watcr near the bank, and I was hiding behind my own rod, as a friend puts it, when I angled for him. He must have seen the rod, and me, clearly, and yet he took the shrimp the moment it eame near him. If only we had had rain, even a little rain, to freshen things up, I believe some of his fellows would have proved equally accommodating. But we had no rain. If I live to be a very old man and visit Penydwddwr twice or thrice a year, I have hopes of some day getting the right conditions for fishing. Then it would be something uneommonly like Paradise. 


\section{CHAPTER XI}

\section{THE DUFFER'S FORTNIGHT}

IT begins somewhere about June 1-maybe a little earlier, maybe a little later, according to local circumstances and the nature of the scason. A warm spell may hasten it a little, though it does not seem so certain that a cold spell will delay it much beyond the datc which eustom has ordained for its beginning. At any rate, it will probably not delay the duffer, whatever it does to his fortnight, and he will be anxiously expecting his opportunity on a given day every year. "Duffer's fortnight" is not at all a bad name for the Mayfly carnival, though it needs a somewhat more elastie interpretation than has usually been given to it. Presumably it was first so called because of an impression that when the Mayfly was on the duffer could show himself an angler. The origin of the expression is lost in the mist of antiquity, so it is unsafe to assert too confidently that it was not so in those days. Perhaps it was so. The veriest bungler may then have been able to fill his creel, and his pockets, and carry the residuum of three-pounders slung on a withy 
twig. We cannot say that it did not happen like that in those good old times, because we simply do not know.

But we can say heartily, and with one accord, that so far as the present is concerned the true interpretation of "Duffer's fortnight" is "the fortnight wherein the angler proves himself a duffer." You do not carry any residuum of threc-pounders on withy twigs nowadays. Your pockets can be kept for their proper functions, as receptacles for tobaceo, matehes, fly-boxes, and the like, and your creel will always have room for a big bunch of marsh marigolds, or other trophies, with which the fisherman likes to fill up emptiness, and at the same time to placate his womenfolk at home. After giving many and wonderful proofs of incompetence in one direction, it is pleasant to be able to show signs of abilities in another. To be able to recognise marsh marigolds when one sees them and thereupon to gather of them largely does afford some consolation. "If I can't catch fish I can, at any rate, appreciate flowers" - that is the sort of attitude. Later in the year a habit of secking such cxtrancous comfort may be even more useful, as when the meditation runs, "I don't care much about fish, but I do like mushrooms." This, however, is a digression.

The Mayfly is an extraordinary insect, and it 
produces extraordinary results on, in, and about a river. Observing it in its numbers for the first time, you would hazard a guess that a river must be very prolific to stand the drain on its resources that is undoubtedly going to take place. There, on the one hand, are all the trout intent on feeding to such a degree that they hardly take notice of their natural enemy, man, as he stalks along the bank. There, on the other hand, is the whole army of anglers turning out for the destruction of the said trout, armed with every device that can make their victory certain. The contest is surely going to be very unequal, and you begin to wonder whether this is sport or a form of butchery. A short Act, The Trout in Mayfly Time Preservation Act, oceurs to you. Its scope may be gathered from the shorter title which you also think out, The Ten Brace Act. Obviously, unless some such provision is made for the future, trout which bchave as those trout are behaving in the presence of anglers who look so capable and well equipped as those anglers, are to all intents and purposes an extinct race. Most of us have had some such impression in our time. Some of us even find it recurring year after year when we get the first glimpses of the Mayfly rise. But it passes like many other first impressions. There is no better cure for it than to take a rod and begin under the hot sun. 
On the whole, the worst feature of the Mayfly rise to the disillusioned angler is the remarkable contrast between possibilities and performances. He finds all the big fish, which at other times are just traditions or, at best, dimly-seen shadows, become concrete realities which wallow and splash and surge over the whole stream. They are all fecding or waiting to feed, or taking a hurried interval for digestion so that they can begin again, and it looks as though a man could iardly fail to eateh as many as he may want. But when he comes to put the matter to the test, he finds that things are not at all what they seem. Most of the fish are bulging, as may be gathered from their restless journeys hither and yon. Of the rest, a good proportion have come to the stage of discrimination, and will have even the natural fly just so or not at all. An artificial fly obviously can never be "just so."

There remain just a few "possibles," and the angler's relations with them are commonly as follows : (a) Fly pulled away at the eritical time, and first possible put down; (b) fly scized by a quarterpounder in a barefaced manner, to second possible's disgust and retreat; $(c)$ and $(d)$ two sixpenny flies left in two three-pound mouths; (e) fly hitched up in trec behind just as fifth possible has made up his mind that he can manage two more, and two more 
only; $(f)$ fly floats beautifully over fine possible of at least four pounds, and is taken without hesitation. Battle less strenuous than was expected. Reason apparent later when possible turns out to be one and a quarter pounds, which is a quarter of a pound under the size limit; $(g)$ another sixpenny fly left in another three-pound mouth; and so on.

All this happens amid a scene of general turmoil, which adds to the angler's naturally overwrought condition of mind. Finally, he is reduced to a wild state in which he rushes from place to place and fish to fish, thrashes the unoffending air with his protesting rod, and generally does his best to prove that he is as a fact a duffer engaged in his fortnight. He returns home in the cool of night with a solitary two-pounder, which he eaught on a sedge after the Mayfly hatch was over for the day, and wonders why things should be ordered as they are.

They say-and, of course, many of us know that it is true-that the duffer's fortnight is not all like this. Provided you are able to see the head and body and tail of it, you may get a true Mayfly day, a day on which big fish are in the mood and on which you can piek and choose, as is the delightful theory of Mayfly fishing, and come home with one or two really fine specimens, which you have besicged and conquered in the approved style. You 


\section{THE DUFFER'S FORTNIGHT}

will have nothing to say to two-pounders on such a day, for their betters fill your eye, though if you chose you could levy big toll on them. Such days are on record.

Two or threc brace averaging four pounds-there have been such baskets, and possibly will be again. There are waters where the thing could casily be done with a stroke of luck to help. And there are watcrs which offer greater inducements to effort even than these, waters where lurk real monsters, hardly secn all the rest of the ycar execpt as an occasional wave and a splash under a glittcring cascade of small coarse-fish fry, but possibly to become surface feeders on one or two days of the duffer's fortnight. The ten-pound trout does exist in some rivers, and he has been seen feeding on Mayflics as heartily as his smaller brothers. But cven to get a rise out of him means a waiting game, for he docs not come up for the Mayfly as a matter of course. The best you can hope for is that he may come up. And if he comes up you may not be able to do anything with him. Still, it is worth a June fortnight even to have watehed such a trout fecd.

That is the spirit which has animated nearly all my Mayfly fishing for ycars and it cxplains, if it docs not altogether cxcuse, a very poor total of fish 
eaught in relation to the amount of time and enthusiasm expended. One season, I remember, which I spent on a portion of the Kennet noted for its big fish, yielded almost no trout to me though other rods were getting their three-pounders and one got a beauty of over five pounds.

I hardly got a chance of a three-pounder that season, the reason being that I spent practieally the whole time right at the bottom of the water waiting for my cight-pounders to begin to rise. There were eight-pounders there-at any rate there was one, for I saw him one day but a few inches from my eyes; I was looking over the campsheathing and he was swimming slowly upstream close beside it-but the trouble was that there was no Mayfly, or not enough to make the big fish rise. Day after day the appearance of odd flies encouraged a hope that the rise was just about to begin, but day after day it stopped short of the desired point. So I got no sport worth mentioning and never saw one of my eight-pounders take a fly.

I have spent other seasons quite as unprofitably, but I have usually succeeded in getting at least one rise out of a fish which has seemed to me worth long waiting. The ambition to get a monster has of course given me some thoroughly dull days, dull at least so far as active employment is concerned. 
I remember one snatched with difficulty amid the stresses of war-time which almost beat my own record of nothingness.

It differed from previous days of the same kind in that the train of arrival was an hour earlier and that of cleparture an hour later, with reference to the sun, than of old owing to the new summer-time business. 'The Mayfly does not know about summertime, or, if it knows, it is like those valiant Northamptonshire farmers, who were said to have greeted the new measure with contempt and contumely, and does not care.

The day was hot, distempered by fitful, thundery gusts. The available shade was limited to one extremely insufficient willow, hardly big enough to make a cricket stump, let alone a whole bat. This tree, though it did not exactly wither away like the scriptural gourd, was almost equally deceptive because of its immobility. In the morning and the early part of the afternoon it offered a little protection provided I crawled round as the sun's angle altered. Afterwards only by sitting in the river could I put the treclet to any use as a sun filter. You will deduce that I did not do this. But carlicr I spent a good many recumbent hours. I was mostly occupied watehing insects on and about the water-a wonderful show of fly life. At times my 
eyes may have closed; I do not remember. Certain it is that there was no occasion for using the rod in spite of all the fly-alder, button, sedges (various and many), olives and their spinners, black gnat in droves, yellow May duns, and occasional green drakes. Not a fish more important than a small dace moved to anything.

It was about four o'clock when the Mayfly began to hatch, induced thereto by an interval when clouds covered the sun. But the clouds passed, the heat returned, and the hatch ceased abruptly. I left the riverside thereupon in quest of some sort of meal to hearten me against the work in prospect when the fly really should come on. I timed the thing well, for the hatch really did begin as I returned. And a very good hatch too. But I camnot say that it made much difference. The dace dimpled a little more freely and may have been a bit bigger, but it was long before I saw a trout, one of those few big ones which the water holds, make any sign of life. So there was still no fishing to speak of. One gets soon tired of spoiling Mayflies over dace. After a while, howcrcr, there was a plop from a heavy fish, and up he came again in the stream between the two eddies, the place where day dreams had figured the record trout a-rising. Not to waste words, he took at the first fair cast, and plunged deep down into the twelve-foot pool, 
strong as a submarine. The real thing at last! But the triumph ended in a netful of silver seales and red fins-a distressing four-pound chub. And there was a similar triumph a few minutes later-a threc-pound disappointment.

Further, there was nothing to record until almost the last moment when a move had to be made upstream in view of the last train for home. Then at a corner (where by the way in the morning was seen a great length of something which head-andtailcd once, but seen from such a distance that it might have been a trick of the imagination), at that corner was evident a fecding fish of great size. And it cruised on a definite bcat, up and down, a hopeful sign. It was a long cast and an awkward owing to a bush and tall rushes, but at last the fly reached the right spot, was taken, and ye gods, what a moving of the waters! That, alas! was all, for the line came back without the fly. There sad, and so home, as Pepys said when the minikin string broke. A bad end to a poorish day. But it was worth while to have had it, if only to see that monster swirl. He may have been another chub of course, a colossus among chub. But I hold that I am cntitled to be of different opinion. In fact I must be, in order to justify my attitude towards Mayfly fishing in general.

That day was in 1916. I also had a little Mayfly 
fishing in 1917 which I will duly record, since it fits in well with the scheme by which my sport with this fly is ordered under Providence.

At any more normal period I should have made bold to complain a little. I still do not think I was treated well. Providence does things too thoroughly. It began by tantalising me with the sight of a Mayfly sitting on a sailor man's white cap in the Baker Street-Waterloo Tube Railway.

I might so easily have been spared that unusual sight. Come to think of it, you might travel the line year in year out for a decade and never see the like again. It was a real live Mayfly, not an imitation, which, I imagine, would be contrary to the King's Regulations and might be provided for under some comprehensive article. For the insect itself I am sure there is no provision of any kind.

Well, as I say, I saw that sight, had speech with the unconscious wearer of the cap, and deduced that the Mayfly was up in a district where I should be on Bank Holiday. That, of course, set me to thinking about fishing in spite of much graver preoccupations which then were mine.

For in that district lives what an amusing writer has called "the occasional trout." What better opportunity of making the acquaintance of that mysterious but attractive fish? I have a firm conviction that he is never under three pounds, 
and usually somewhere between seven and ten pounds. To be brief, I laid all my plans for catching him, and proved to my own satisfaction at those rehearsals which take place on the edge of sleep that he was certainly a seven-pounder, and maybe a bit over. Meanwhile I laboured abundantly so as to have a few hours free during the holiday. How fortunate, I thought, that the district is early in the matter of Mayfly.

To condense the story, I succeeded in snatching two evenings. The first was ushered in by a thunderstorm and chased out by another thunderstorm. It was a wretched sandwich of an evening, flattened utterly by the two convulsions on either side of it. Nothing rose which I could honestly claim to be other than dace or bleak. Fly was in evidence, but sparse and dispirited.

The morrow was lovely. It inclined to a fresh wind all day, but as I toiled with papers that did not worry me. About tea time, moreover, the wind began to drop, and my hopes rose. It was going to be one of those perfect Mayfly evenings which mellow from gold to rose, from rose to opal, and from opal to the deep blue of a summer night. I set out across the knec-deep grass, drinking in the goodly seent of the may, and thanking a benevolent Providence for a few hour's of perfection. And so I came, leisurely rejoieing, to the river, at whose 
margin even from a distance I could see the spinners beginning their evening dance.

Thus to the water's edge. I looked down, and behold the river was as soup in a tureen! And so it remained till I came sadly home, having seen a magnifieent hatch of fly with not a fish paying the smallest attention to it. I learnt afterwards that higher up the valley the thunderstorms of the day before had brought with them floods of rain lasting for hours. Which was an explanation, but no comfort. On the whole this was the poorest Mayfly season I have ever had.

In other and better seasons I have had some fine opportunities on first-rate waters, thanks to the kindness of their owners or lessecs, but I have never succeeded in doing anything with them worth mentioning. Somehow or other I always make the worst of Mayfly opportunities, and the occasional successes, which even I have not been able wholly to avoid, have usually left a regret, amari aliquid, behind.

There was one very queer season on the Kennet below Newbury, which started with a deluge, continued with a flood, and wound up with a spell of winter. I got to the river on a Saturday morning to find things not wholly inauspicious. Albeit in a close and thundery air the morning hatch of fly was satisfactory, and for about half an hour it seemed 
as though the fish were about to feed in earnest. Two admirable trout, indeed, turned themselves miraculously into chub in the bricf space that ensued between hooking and landing, while several plump dace made mess of several dainty flies which had been dressed for their betters. Then in the distance arose a dark mysterious cloud, which muttered ominously as it approached.

Having been caught in that way before, and having recently read warnings as to the "conducting " propertics of fly-rods, I retrcated without loss of time, and presently, safe under cover, was, watching a storm of malevolent vehemence, which threatened to stop Mayfly fishing for the day. It not only threatened, but performed, and by 6 p.m. the river was running pea-soup in appalling quantities.

On Sunday it continued thick, only beginning to fine down towards evening; and on Monday, though the river was fairly elcar, the wind arose in its might to rob angling of any small chance it might have had. Some small hatch of fly about 2 p.m. there undoubtedly was, but the wind and cold prevented any rise from anything that looked even remotely like a trout, and the fly ceased abruptly in about an hour.

Dispirited and shivering but inspired with the doggedness of ill temper, I hung about the river 
all the rest of the day, waiting for something to turn up. It was quite 8 p.m. before the wind dropped and disclosed a grey, cold river flowing sullenly beneath a grey, cold sky. So cheerless was the prospect that I made a movement for home and supper, when "plop" and again "plop" caused a hurried return to the river.

Yes, by the powers! there was a great trout feeding close under the camp-sheathing, rising with a cheerful abandon begotten of the Mayfly season. What he was taking was undiscoverable; nothing was visible on the surface, and spent gnats were out of the question; all signs of Mayfly had ceased hours before. Still, there he was, and he must be tried. He was in an awkward place, just in the eye of a swirling eddy, where the first fly offered was promptly drowned. It was drowned a second time, and then taken off to make room for a dry one. This swept down the run, hovered for a second at the eye, and was just about to be drowned, too, when "plop" - the trout had it. There followed a tearing rush straight downstream, through the deep pool, past a bush, over which the twelve-foot rod could just be lifted, and on for the swift water and the thick weeds. Here he would be a free fish to a certainty, for there was another bush in the way over which the rod could not be lifted. Therefore it was a case of butt or break. 
Butt had it, mercifully, and he came slowly and doggedly back, fighting decp, and trying to get in to the bank. Then on a sudden he eaved in, came to the top, rolled over on his side, and so into the net, as pretty a four-pounder as eye could wish to sce, a thought long perhaps for a Kennet fish, but smallheaded and thick-shouldercd.

Now if Providence had stopped there it would have left me with a completely happy and triumphant memory of a great occasion. My biggest Mayfly trout (he weighed four pounds one ounce, and I have only caught one other on Mayfly which just touched four pounds) would have served me as a perpetual and pleasant reminder of the beauty of "sticking to it." But what did Providence do?

It did this. Scarcely was my four-pounder on the bank when a few yards higher up there were more "plops," and another great trout was hard at it in exactly the same way, fecding vigorously on nothing. He was covered, and he rose fair and square, but, alas! a hand, shaking from the recent conflict, had lost its cunning. The response to the rise was too rapid, the fish evidently objected to having the fly pulled away, and went down, to rise no morc. Marvellous to relate, twenty yards higher up yet a third big fish began to feed almost at once, but there was more excuse for missing him, for he was right under a willow bough, and could 
only be reached by a side flick, in the course of which the line got entangled in the nettles on the bank. Therefore, though he took the fly all right, the rod could not get on turns with him, and he departed untouched.

Think what a leash it would have been, for the other fish were quite as big as the one I caught! But Providence evidently meant me to suffer the pangs of regret, and to make sure of it, sent me to the same spot on the following morning. Then, a few yards lower down, I at once hooked yet another four-pounder, played him for several minutes, and was just preparing to use the net, when a voice said "Hi," or "Good-morning," or "Any Sport?" or some other offensive thing, my attention was distracted for a moment, and the fly came away. For twopence I would have pushed the owner of the voice into the river. Providence I would have pushed in for nothing at all had $I$ had the chance. I have never had to do with four such big fish in such close succession before or since.

Francis Francis and others used in old days to begin the Mayfly season on the Itchen and continue it on the Kennet, thus getting some three weeks of fishing. One season I tried to emulate this achievement and pursued the insect to three different rivers. It was not a great success. Here is the record of the business as I set it down at the time. 
I leave the confession unaltered as it points a moral or two.

"Therc was a certain piquancy about my first vicw of the Mayfly this year, because it came within a week of my last vicw of the March brown, and I was able to compare the creatures with a freshness of interest that was gratifying. I remember thinking well of the Mayfly, and disparaging the March brown, because I was sure that the larger and later insect would make ample amends for the scandalous behaviour of the smaller and earlier. Now I want something larger and later still, which shall make good the abominable deficiencies of the Mayfly. Not to put too fine a point upon it I should like dragon-flies to become trout-food all through July and to enable me so to eatch something. I badly desire to have some satisfactory standard of comparison by which I may disparage the Mayfly thoroughly and reduce it to the level of the yellow May dun which trout do not take. They do not take the Mayfly either, of course, not really, but people think they do. I wish to exposc that fiction by the aid of a dragon-fly carnival and enormous fish safely landed with No. 10 hooks. Pcople would know then that the Mayfly is not the real thing.

"By way of preparation for this, let me with bricf dignity relate my experiences. First there was a day on the Surrey stream which of old misled 
me into the idea that the Mayfly was a none-suchI apologise for the expression, but it dates from Cavalier-Roundhead days, and my mood is Roundheaded. Well, on this Surrey stream I saw such plenty of Mayflies as never was before. Usually twelve flies in an hour make you excited, and twentyfour are the cream of the cream. But on May 14 I saw more flies in five minutes than would last half an ordinary day. And the fish ignored them, practically. The manner of their bchaviour was this. Upstream, a hundred yards or so away at a vague point A. round a corner, would come a resounding splash, and I would hurry thither to await its repetition. Ten minutes would pass, and then would come another splash, somewhere near the spot I had left, an indeterminate B., and I would hurry back. Followed more waiting, and then a third splash at or about A. Renewed expectancy there would be rewarded by a fourth splash-at $B$. Why, a man will ask, did I not display presence of mind and remain at B.? I tried that. The result of it would be two and even three splashes at $\mathbf{A}$., which was more than human nature could stand. Also I tried casting at the place where the rises seemed to be as judged by the ear. And that was more than the trout could stand.

"The day yielded me one wretehed trout and one indelible disaster. I did at last find a glorious 


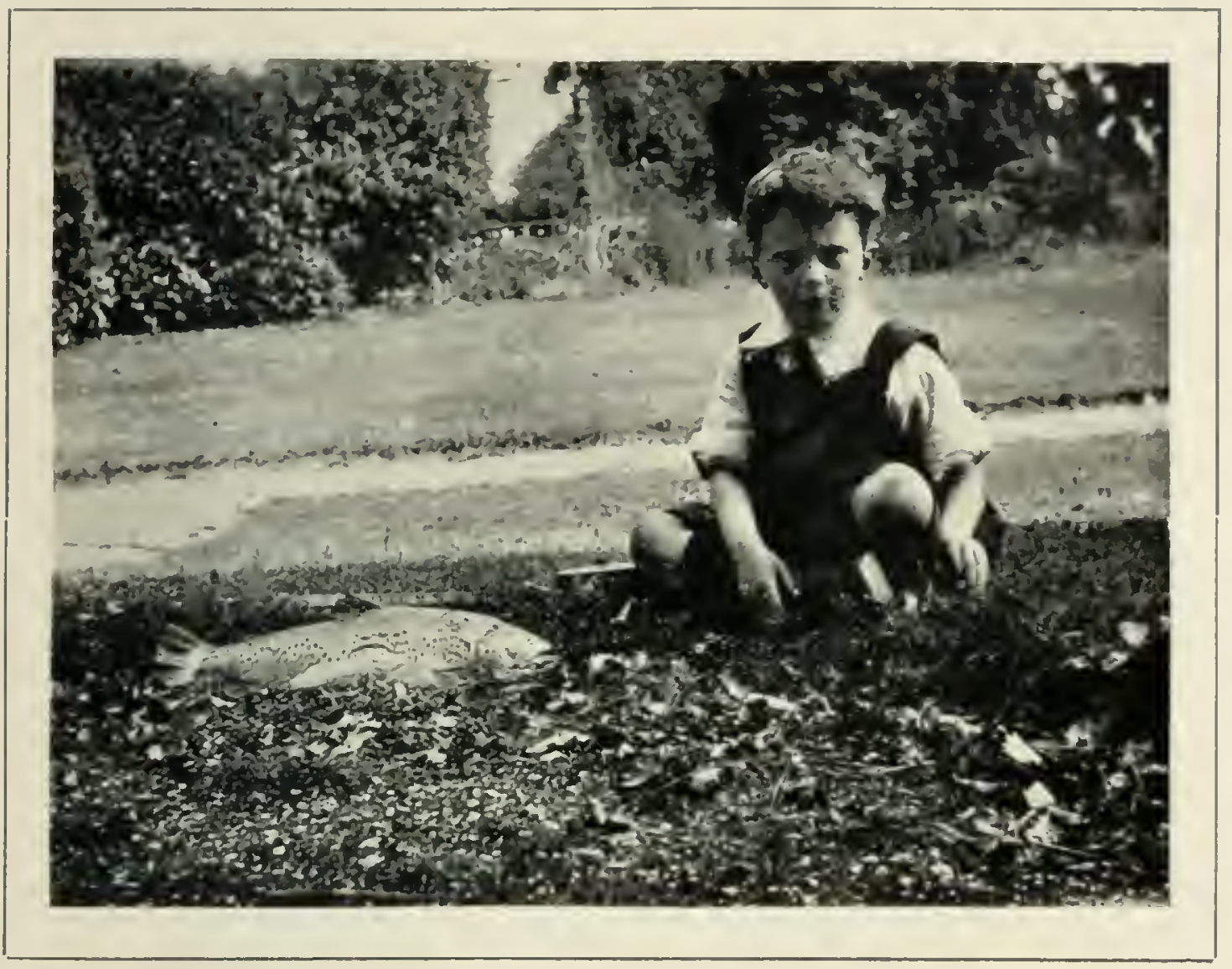



fish fecding persistently, an casy fish, a fish close to my own bank, a five-pounder. He was what, from hearing about other men's sport, I have learnt of late to call a 'sitter.' I fished for him as I imagine those other men do, with no mistake, no drag, no mischance. And he took as those other men's do, felt as heavy as theirs, made my reel scream as theirs-and got off as mine do. Sitters!

"Now let me tell of the visit to one of the most charming streams that join the Thames, with one of the best of fellows and hosts that ever cast line. The Mayfly had appeared ten days too soon andwas over.

"And now let me sing the Kennet, and the Brethren, and the seven streams and seventy carriers and seven hundred thousand three-pound trout, which all welcomed me in pouring rain. Even as I got there I trembled at the sight, so much was the fly and so furious the rising of the three-pounders. It was a bewildering spectacle to a man who had known trouble. The Brethren as usual were admirably ealm and surveyed the seene unmoved. 'When,' they said, 'the rise begins, we'll put him on the Grove.' I was specchless. 'When the rise begins!' 'Isn't,' I presently said feebly, 'isn't this a rise?'

"It wasn't. 'The rise began at two. I saw a great river simply heaving with three-pounders, 
and naturally my mind became unhinged. I rushed up and down the seven streams and the seventy carriers, and the seven hundred thousand threepound trout rushed too; we all rushed. My rod went up and down like a flail, my fly fled hither and thither like a snipe, the sun came out, the sky took on a blue face-it was a mad and merry time. I arrived at the point of tea with a brace weighing just under four pounds, and I expect I ought to have had five brace weighing forty.

"And then after tea there was the five-pounder to be caught at the point of the island, and the four-pounder under the hedge, and much more to be crowded into a delirious evening. To reach the five-pounder needed a twenty-two-yard cast, with about five yards of slack over and above to counteract the weed bed and the eddy. But the strength of the insane was upon me, and after a strenuous hour I succeeded in losing him. And I lost a three-and-a-half-pounder just below him, and a three-pounder just below him, and the fourpounder under the hedge, and had other brave doings worthy of the opportunity and of me. The end of it all was one more fish below the size limit, which had swallowed the fly and made himself bleed. What a day it would have been for a calm, capable person who had not known trouble.

"I could tell of another day on a water scarcely 
less desirable in my cyes, a day spoilt by floods of rain and a thickening of the stream, and of another day when pusillanimous retreat before a storm deprived me of the half-hour in which the trout really were on. But what is the use of more ado? How am I to persuade trout to take dragon-flies, and so repair my fortunes? That is now become the question."

One more moral and the chapter must come to its close. This is connected with the conditions which prevail on a hard-fished ticket-water on which I took a rod one ycar.

With the Mayfly on the wing every single soul who could be on the water was on the water, which meant a considerable congregation of souls. And that meant what is pleasantly called "intensive" fishing-that is to say, wherever you happened to be a brother angler would be within exclamation distance, possibly even within a whisper. Where there are plenty of trout intent on Mayfly this does not perhaps scriously affect sport, but still, one prefers a little more elbow-room when one can get it, if only because exclamations are not always intended for other ears. Also I still hold, despite sca-angling festivals and the like, that angling is of its nature a solitary diversion.

I got out none too early (several experiences on that water ultimately convinced me that to 
make sure of the rise you should be out with the lark and home with the owl), and I received a delightful surprise on finding myself quite alone on the first stretch I came to, where the smaller river rounds a corner lined by trees on the far bank. This smaller river is not of so much account as the big one, and though it holds good fish, it has the reputation of being dour. Besides, it is later than the other, and the Mayfly was not really due on it yet. It seemed to me that so far it, or, at any rate, this topmost, rather inaccessible, corner, might have been overlooked.

Having evolved this theory, I saw several Mayflies and, immediately after, poised near the surface a trout of such calibre as I had not deemed possible in the stream. Then I saw another even bigger, and after him three more, all big and all in evident expectation of the hatch. "This," I said to the solitude, "is good enough. Here I am; here I remain." I will not deny that I was excited. To have lighted on a practically virgin piece of water during the Mayfly time on one of the hardest flogged fisheries in England was a piece of superb luck, by which I hoped to profit to the tune of three brace weighing at least twelve pounds. Afterwards no doubt the stream would be fished as intensively as the rest, but for the moment I scemed to be not 
only alone, but also the first to burst into that silent seene.

Let me now confess that the affair did not turn out quite as I had hoped. Those large trout, so visible and apparently so ready for me, displayed an unexpected amount of self-control. I laboured over them for about an hour, and the net result was three short rises. It struck me that they could not really be on terms with the Mayfly yet, and that they might be the better for a rest while I had lunch. One thing was practically certain-they could not fail to come on some time, when the fly should get a bit thicker, and then, not having seen any other artificial flies, they would certainly take mine.

So I lunched, sitting peacefully on my basket, with one eye cocked for a proper rise at a flyso far it had been a matter of oceasional bulges after nymphs. To me, thus sitting, entered then he whom I shall eall the First Angler, both by reason of his priority and of his acknowledged skill. With him there was a pleasant chat. In the course of it it appeared that he knew all about the corner. More than that, I learnt that its fishable condition was due to him, for he had recently been among the withies with a pruning-knife. The result, easy casting, combined with good eover, did him great credit. But it was evident that $I$ was in no sense 


\section{TROUT FISHING}

a discoverer. Probably, indeed, the good fish which he had lost early that morning was the topmost of my five.

I was still sitting on my basket meditating whether those big trout were, after all, quite the untutored beings I had hoped, when the Second Angler arrived, to take up a watchful position some way lower down. A common boredom (the rise had either petered out or not properly begun) caused us to drift together eventually, and to converse awhile. From our talk I gathered that the corner was not only the favourite resort of, but had even been named after, the Second Angler. I became doubly certain that I was not its discoverer.

Presently, the Second Angler having gone downstream, arrived the Third Angler. "Yes," he said, "I had hold of a good one there this morning," pointing to the spot where No. 2 (of my five big ones) had been displaying his massive charms. The Third Angler confessed to not being a patient fisherman, and departed, after assuring me that the bottom of the water was the best place thus early in the rise. Soon after I went away myself to get some tea, as nothing was doing and the fly had not yet begun.

I stayed away too long. The Fourth Angler, who was hard at work when I came back, and who landed two or three fish while I was getting to work 
again, pointed out the exact spot where he had just lost a four-pounder. The fly must lave appeared the moment it caught sight of my departing form, and the Fourth Angler cannot have been long behind it. But the take, such as it was, was over by the time I got back, and I saw no more big fish move. My friend's big trout, by the way, was not one of my original five, but a fish some little way below. I knew about him in the morning, and had mentally decided on him for the completion of my three brace-he was a worthy fish.

I will now pass hurriedly to the late evening and the Fifth Angler, who was plodding philosophically home. I had left the corner by then, and was waiting about for sedges lower down. "I've only got a brace," said the Fiftl Angler, "but I had bad luck. I lost three really good fish up at the top under the bushes on my way down in the morning." So there were the rest of my big ones duly accounted for!

The moral is that a corner may not be so quiet as it seems, and that visible big fish are not always as good as in the basket. 


\section{CHAPTER XII}

\section{A PECK OF TROUBLES}

MANY is the wise word (borrowed from better heads) that I have written on the angler, and on what he ought to do or ought not to do. Onee I remember I was severe on the folly of forgetting things, not without a sort of righteous pride in the fact that for some time I had forgotten nothing. This was due in part to the working of my new system (whereby everything wanted for a day's fishing is kept in the creel ready), in part to luek, and in part, as I hoped, to genuine mnemonie improvement. At one time I really thought I had made an end of forgetting, and had some notion even of writing further on the subjeet.

I am doing so, but there is, believe me, a difference between this and the might have been. I am not going to blame anybody, not $I$. Here are some of my recent achievements. One day I went out fully equipped, save for the landing-net sling. Let him who has tried to attach a telescopic, knucklejointed net to the inadequate strap of a creel pity me. Let him who, tired of that juggling trick, has 
fashioned a sling out of a piecc of string, and tricd to get the net out of it in a hurry pity me also. On another day I forgot my spring balance, and, of course, it ehanced that I was then on a water where weight, not length, is the criterion by which fish are judged. There may be men outside fish farms who can say for certain whether a fish is one pound nine ounees or one pound seven ounces, but I am not one of them. There are others who would be quite happy to guess, happier, indeed, but I am not one of them either. The sad shake of a keeper's head would annihilate me. So I probably returned several quite sizeable fish.

On the third day I did an extraordinarily foolish thing. Invited to fish on a fine Mayfly water, I turned up equipped with two bedraggled winged flies, three very spent gnats, of which only one was in even fair condition, and one straddlebug that had seen better days. These were the oceupants of my hat-band. Boxes full of admirable flies of all kinds, bursting with flies, lay on a table miles away. The fish proved to be in one of their very particular moods that day, so you can imagine me ringing my miserable changes with equally miserable results. Besides, I very soon lost the best of the spent gnats in a tree. On the fourth day of the series I set out in the morning for a nice long day with the grayling, with hope of a brace of trout if I was lueky. It was 
to be a day of fine gut, small flies, and exact science. The trap set me down at the mill and drove away. I proceeded to preparc for action. I had had the forethought to put two casts a-soak in the damping pouch. It is my custom to soak the points at the waterside, adding so many and of such strength to the main cast as occasion requires. My main cast is quite a strong thing, ending in stoutish undrawn gut, and to it I add four or five points of lessening sizes, so that in the end I have a fouryard cast tapering to $3 \mathrm{x}$. F. M. Halford taught me the merit of a long cast years ago, and now, unless the wind is contrary, I hardly ever fish with less than four yards.

I put up the rod, threaded the line, attached a cast, and then felt in my pockets for the gut-case. It was not there. I was committed to a day's grayling fishing with gut which would be somewhat strong even for the Mayfly, and which would scarcely go through the eye of a 00 fly at all. Then, by a stroke of good fortune, I found two points coiled in the corner of the pouch. How long they had been there I knew not, but I soaked them and tied them on, hoping for the best. Nothing much happened for a while, but presently I caught a nice grayling, and began to think out an article entitled "Lucky Points," or something like that. Soon after, however, I had the misfortune to find a good 


\section{A PECK OF TROUBLES}

trout rising, to fetch him up, and to hook him. And the next thing I knew was that he had gone, fly, points, artiele and all. After that I made a little seeming of fishing with a big Wickham, took no good out of it, and descended to a big March brown fished wet. The Mareh brown flew away in the air, and then I gave it up, and went away to the canal to try for some of the big chub. And then I went away altogether.

Troubles which arise from one's own forgetfulness or foolishness are, of course, hard to bear, but one is forced to admit that they are deserved. There are other troubles, however, which are not, so far as one can honestly judge, due to one's own shortcomings but seem to be the work of a malign Providence. Possibly there is something meteorological at the back of some of them.

There are several matters which at intervals puzzle me as well as annoy. One is the occasional unwillingness of my lines to float for more than a short time. The same lines, dressed with the same unguents, float quite well at other times. They do not seem to be unduly worn, and each has its proper period of rest and drying, but on some days they all behave badly. It may be something to do with the weather, but what I could not say.

Perhaps the trouble is more noticeable when there has been a good deal of thundery weather. 
Perhaps, too, that is responsible for the accursed curl in the gut, from which I have suffered frequently. Up eyes, down eyes, straight eyes-I have tried each kind of hook, and the gut has curled with each. Of one thing I am certain-the trouble has been worse with drawn than with undrawn gut. But it has not been of daily occurrence. The same gut which curled on Saturday might be as straight as a ruler on Monday. As I always soak it well, I am coming to the conclusion that the weather is in some way responsible. We have still a lot to find out in connection with fishing.

Another trouble is harder to define in exact terms, since it is rather displayed in a state of affairs than in any particular incident. Consider the following cumulative series of little annoyances.

Twenty yards above the railed inclosure whither the cattle come to drink a handsome trout is rising just at the tail of a streamer of weed. The current at this point is of even flow; there are no difficulties in the shape of trees or bushes at the side or behind; the wind is barely perceptible. To all appearances it is an easy matter to put a fly properly over the spot, and in due course to get a rise out of the fish, lying as it is about two yards out from the bank. Yet at the first trial, though the length of line has been judged correctly, the fly shoots off at a tangent 


\section{A PECK OF TROUBLES}

and falls nearly two yards wide of the mark, the cast lying in an irritating loop.

Line is recovered and another effort is made. This is frustrated by a sudden jar at the rod-top at the third false cast, the fly having come into violent contact with the rod during its forward progress. It has to be discntangled, and it is found that the gut-point is twisted several times round the top. It must be carcfully straightened and wiped with the handkerchief to get rid of any grease that may have got on to it from contact with the line before the attack can be resumed.

The next cast falls wide of the trout on the other side, and after that there is an ominous crack in the air bchind - the fly is whipped off. A new fly does not take long to put on, and soon the rod is at work again. This time both ain and distance are correct, and the fly falls at the right place, but-it falls heavily like a small brick, and the trout is put down for the morning. Over the next rising fish discovered a similar set of incidents occurs, and when at last all difficulties of approach are overcome, and a third trout is fairly risen, the hooking of it is found to be impossible because the reel line has begun to sink.

These events of a dry-fly morning, repeated with variations through all the hours of it, are related not 
in a tone of complaint (though there is usually some of that at the time), but in a spirit of inquiry. Why is it that on some days everything goes wrong, not so much with the behaviour of the fish, for that is more intelligible, but with the performance of the fisher? He feels in normal health; there is nothing the matter with his zeal; the light is good, the wind no hindrance; and yet he cannot for the life of him make his fly do what he wants it to, even though at normal times he is a fair performer.

To reach a certain spot he first tries the ordinary easy cast, in which the rod does most of the work, and gut and fly fall in a ghastly heap. To counteract this at the next attempt he puts a little more force into it and adds a downward cut; then the fly falls with a splash. Next he essays an underhand cast, and gets hung up in the nettles. After that, a trial of a strictly vertical position catches the hook in the top ring. No matter what he does, he does wrong, until a day which dawned with fair prospects and promised tranquil pleasures produces violence and gnashing of teeth. Should his adjoining neighbour, as generally happens, choose that moment to discmbarrass himself of superfluous weeds, the condition of the fisher is likely to be very serious indeed. Floating weeds in addition to the other troubles are quite enough to develop any homicidal tendencies which may be latent in the most placid of natures. 


\section{A PECK OF TROUBLES}

That, however, is beside the subject, and the real question remains unanswercd. No doubt there are answers more or less satisfactory, but it is hard to see them. The personal element has been eliminated because the fisher is not "off eolour." If he were he would not be surprised, but he knows he is not; he slept soundly, and ate a large breakfast with hearty appetite. At starting he felt himself a match for any kind of difficulty, and the master of all methods. There remain impersonal things. Is it anything to do with the rod? "I am sure rods get tired," said an accomplished angler to me one day, "especially split-cane rods; but they reeover all right after a rest." It was a very suggestive remark, which may possibly have some bearing on the point at issue. If a rod does get "tired" and the day of troubles comes after it has been through a spell of hard work, one need not be surprised that it refuses to behave properly.

Yet this sequence of events is not invariable, for the troubles often come when the rod has had no work to do for a long time--often, alas! on the solitary day which the angler has snatehed for fishing out of a busy life. The rod seems to be also climinated by this very fact.

Another possible solution remains-wind. Are there, even on days apparently all but windless, awkward little currents of air near the surface of 
the water and ground, too slight to be perceptible, yet cogent enough to spoil the neat finish of a dry-fly cast? If so, are they of no fixed direction, blowing where they list, so that the same zephyr which frustrates the first easy cast by opposing the fly brings the downward cut to nothing by turning wilfully round, and helping the fly along? The more one thinks over the problem, the more one inclines to this explanation, though it brings small comfort in its train.

There are many other kinds of trouble to which we anglers are heirs, and which we have to endure as manfully as we may. One of the worst perhaps is the loss of fish after fish for no apparent reason. There must be a reason of course, and I have come to be of opinion that the fault lies less with the angler (though it is right and proper that he should blame himself - that way lies humility) than with something in the condition of light, weather or water, which makes the trout take the fly gingerly. There is no mistaking the days on which fish take wholeheartedly. The merest trifle of a 000 hook will then suffice to hook and hold a three-pounder. But on the other days such a hook hardly seems able to inflict a scratch, much less to get a hold. And even the sort of hook you use for a Welshman's button or a March brown, a good sensible No. 3 or No. 4, is of very doubtful efficacy. Perhaps the trout 
on these days do not really elose their mouths on the fly, and when one tightens on them the look gets no hold at all or at best an indifferent lodgement in some outlying part of the jaw.

In rather similar eategory are the wet-fly days on which there are many rises that lead to nothing. Here again the angler is prone to blame himself, to think that by striking more swiftly, or more slowly, he might have made better use of the opportunitics. I do not belicve that this is so, in the case of any angler of fair skill. I think that the trout which rise in this way, making a lot of show but not getting hooked, do not mean to take the fly at all. They are interested enough to gambol close to it, but not to make trial of its flavour.

Nor do I think that it is often accurate to say that a trout " missed" the fly. It does happen sometimes in a lake when a fish has come out of the decps that he "loses" it, but the angler usually helps therc by pulling it out of the water prematurely. If he can get it in again while the fish is still looking about like a terrier for a vanished rat, he will probably get a real rise. But a genuine " miss" must be very rare even in rough water. A trout has a very good aim, though he is perhaps outdone in this by a grayling, which can come up from dcep water and seize a fly on or near the surface with marvellous precision. 
Another trouble, frequent on the chalk streams though less met with on other waters, is weeds, both on and below the surface. The miseries inflicted by weeds floating down the Test or Itchen on fine fresh mornings of May and other months could inspire a whole series of penitential psalms, with a supplement composed of versified objurgations. Though no poet myself, I would gladly contribute to the volume.

There is perhaps no problem of the chalk streams which produces more heart-burnings, more abuse of one's neighbours, than this, unless it be mudding carried on at untimely periods. There is one real remedy for it and only one-that every fishery should take out its weeds as it cuts them. When the Hampshire rivers adopt this system-it is enforced by the conservators on the Thames and its tributaries, which include several chalk streamsthe first weed trouble will to a great extent have disappeared. The system of course involves some extra expense in labour and in the provision of weedracks, fixed or movable, but considering how valuable chalk stream fishing is and how short its season I think the outlay ought to be worth while.

The other weed trouble is caused by the fish, which like their weeds thick and strong and handy. 
Some trout are much more prone to go to weed than others. I remember getting scveral good trout of about two pounds from the Avon one hot summer when the weeds had not been cut for some time, and each fish seemed to be in a little round hole with a belt of thick herbage protecting him on every side. It was most interesting and attractive fishing because there was little or no fly, and hardly any stream in the holes, and one had to stalk one's quarry, lying near the surface probably from force of habit, and drop a Wickham or a red quill as elose to its nose as possible. The trout took the fly well enough, when one got the preliminaries right, and the odd thing was that they made little or no use of the weeds. I remember no interludes of hand-lining. Casualties there were, certainly, but mostly due to my custom, when possessed by panic, of pulling a fly away from a fish or clse of trying to do so too late and leaving it in his mouth. Twopounders visible in small round holes usually give me panic.

As a contrast to this fishing I remember a day on the Gloucestershire Coln when fish after fish ran straight into the weeds on being hooked and mostly remained there. Hand-lining, which is effective in some cases, was, useless there because as the weeds were not very thick the fish improved them by 
running through, then coming back, and if necessary running through again. They were very thorough about it.

The oddest, and perhaps the saddest, experience I ever had with weeds was when a trout in a branch of the Test tried the expedient of diving straight down into a bed after a high jump into the air. The weeds were very dense and the unhappy fish just stuck in them with his tail-end in the air. $\mathrm{He}$ could not move, I could not move him, it was too deep to wade, so I was forced to pull the line till the gut broke and so leave the affair. Whether he ever escaped I do not know, but I fear not, as some hours later that lamentable tail was still in the same position. He was not a sizeable fish and would have been duly returned had he not tried what our airmen call "stunts."

Some trout fishing troubles are less tangible than those caused by wind, weeds and other things that one can recognise and blame, or even than those caused by things that one can surmise, such as "tired" rods. One of the queerest perhaps is the depression that comes of failure after success, the sense of futility in contrast to an earlier suspicion of being a man of parts.

A priest once told me that intellectual pride was a very grievous sin, and I believe he was right. Like all grievous sins, too, it brings its proper 
penaities, sometimes hastening, sometimes lagging, but always following in its train. Every human preoccupation may lend itself to the indulgenee of this pride, fishing no less than the others, and I know that the sequence, sin first and penalty afterwards, may be expected by the river as in the street, the mart, or the chamber.

One Friday evening I reached Winchester blissfully conscious of several clear days for leisure and the dry fly. Unhurried, I sauntered to the Itchen with about an hour of daylight left, and, caring little whether I killed a fish or no (was there not store of days in front?), tied on a female blue-winged olive. I was proudly conseious that it was a female blue-winged olive, and pleased that I, who never ean remember these subtle distinctions, actually had remembered them and profited by the teaching of the master a short while back. I crossed the two planks, threaded my way through the little wood, and gained the meadow, where my big fish are (they are not really mine; the wish is parent to the expression), in a mood quite ripe for committing the grievous sin hereinbefore named.

Everything conspired against me. I found four trout rising. 'Two rose, refused the fly, and went about their business. The others I killed in the inevitable mammer that marks the really skilful dry-fly angler. A well-judged attack, a perfectly- 
placed fly, a timely strike, and a light yet controlling hand-these distinguished the achievement; and the brace weighed respectively one pound nine ounces and one pound ten ounces-very handsome fish. Honour thus satisfied, I essayed no more slaughter, but turned serenely in my tracks and strolled homewards through the dusking meadows and under the solemn avenue of over-arching trees.

My thoughts ran somewhat as follows: "Here am I, knowing the difference between blue-ringed olives, male and female, which in itself is much. But more than such book-learning, here am I able to profit by it. Half an hour by clear-flowing Itchen, and, behold, a brace of noble trout ! Marryat himself could have shown no better result. If I am able to do this in a first brief thirty minutes, what shall I not do in the many hundreds of minutes which lie before me? Positively I am a menace to a fishery; ut puto malleus fio. But no, I will not tell the tale in dozens. I will hold that terrible hand; I will hammer discreetly. And my reasonable number of trout shall be made up only of the finest and fattest specimens that Itchen affords. Twopounders I will retain; the rest I will return."

So climbed my thoughts, and even to worse eminences, which I forbear to describe. It only shows what a great and besetting sin is this pride that so much pother should come of a brace of 


\section{A PECK OF TROUBLES}

trout, even though they were caught not unskilfully, as still I maintain, for all the chastening that eame after. I am the less indisposed to say so because I soon felt as though I should never have either wit or luck to catch any more trout at all! So much for the sin, and now for the chastening.

On Saturday I put on wading stockings because, as everybody knows, they are extremely useful for kneeling about in moist places, fending off the penetrating attack of wet grass, and so on. The result of this was that everything, moist places, grass, and the rest, was as dry as a bone, thanks to warm sun and airs, with the sole exception of the waders themselves-inside. They after the manner of their kind condensed, as a learned friend of mine calls it, like anything.

They were heavy, cumbrous, and the plague of my life as I toiled from place to place, upstream to get sight of the rumoured four-pounder below the bridge (and I saw disturbanees which might have been he), downstream to the little inn where tea was to be had, and close to which a fish of cight and a half pounds had been caught on bread a few days before (a poor spirited fish, so the landlord told me, which fought not at all), and round and round as I avoided the bull who lords it over the meadow which is the gateway of the fishery. It is two gateways really, because in it you may strike 
either the main river or a side stream. And when I yearned to fish the one there was the bull waiting for me in the path, and when the other there was he also. So, of course, I had to go round and round. He did not, I think, like my hat, which is a large hat and a sensible; it is resented by all four-footed beasts and by some who have only two feet.

To return, nay to come, to the fishing, the long, long day yielded me two smallish trout and one smallish grayling, and as for skill, and comparisons with Marryat, and nonsense of that kind, I blushed for that self of the evening before. After losing five or six fish and putting down all the others there was precious little pride left in me. I crept home under the now gloomy avenue a humble man.

On Sunday there was no fishing, but a great peace born of glorious music echoing down the cathedral, and afterwards of slow wanderings round the precincts, whose fair paths, smooth lawns, and ancient houses, with deep-blue sky overhead and sunlight flickering through the trees, are like a dream-picture of some golden age. If the spirit of Walton ever revisits the earth it surely does not wander far !

On Monday, still humble, but refreshed by the spirit of old Winchester, I came to the fishing again, hoping for a modest little basket which might enable me to work off an obligation or so by means of a brace of trout here and another there. But I 
had not yet paid my penalties, and my score was one smallish trout and two smallish grayling, with, imposed on this defeat, an appalling disaster. During the evening rise, which was not a rise but a display of " oncers" (Red Spinner, all men thank thee for that word !), I hooked the biggest trout I ever had to do with on the Itchen. And the fly came away at the end of his first rush of nigh thirty yards! Tuesday may be summed up thus: wind, rain, and a twelve-and-a-half-inch grayling. And so back to London, where I found that I had forgotten how to distinguish the blue-winged olives, male and female. One of them had a red head, but which?

This sort of thing repeats itself in my fishing career, for I still cannot forbcar to congratulate myself when I have been successful, nor do I cease sooner or later to regret that I was so uplifted in spirit. I suppose similar ups and downs come to everybody.

There is of course no end to the fisherman's troubles if one came to catalogue them, but it would be a necdlessly depressing task. We anglers do not want any one to anatomise Melancholy for us after the manner of old Burton, though it could be done with the proper wealth of detail and illustration. Melancholy is our companion often enough, without our needing to scrutinise her every feature. 
But there are some troubles which one might avoid by dwelling on them a little and especially those which are brought upon us by the actions of others. Like all other fishermen I have some store of memories which brings this lesson home. There was, for instance, the bright, hot day on the Kennet, when I had been able to do nothing at all. Nothing in particular was rising, and my plan in such a case of looking for fish in position and fishing by sight (often good for a brace on a bad day) had been brought to nought by the fact that the fish saw me long before I could see them. By the afternoon I was depressed and gloomy.

Then came one of those gleams of fortune which sometimes flash athwart the darkest hour. I saw a rise, which was repeated, and then a fine big fish cruising about in a quiet corner. It was a real opportunity. My fly was taken boldly, and I settled down to a long fight. I dared not bustle the fish, because the gut was fine, and because just below was a hatch, for which he might bolt if too much agitated, so I played him gently, and, in consequence, for a much longer time than would have been the case ordinarily. But all went well, and at last I dipped the net into the water and drew the trout towards it.

Then a voice behind me said, "Good-afternoon." I jumped, and looked round, to find an amiable son 
of the soil full of information about the fineness of the weather. And, of course, as I looked round the line slackened, the fly lost its hold, and the twoand-a-half-pound trout faded away out of reach. It was hard in such circumstanees to express any interest in the weather, but I think I managed it. My friend went on his road content, and I believe he never realised that he had witnessed a tragedy at all. The whole fight had been of the quietest, and the fish never splashed or swirled. A spectator might well have been ignorant of what was going on, save for the bent rod. Later in the day I lost another fish of equal bulk, which did not cheer ne at all.

The moral of this incident is undoubtedly this : when you have a considerable fish seen, rising, risen or hooked, be deaf and dumb to the outside world, unless of course it threatens to molest, frighten, or otherwise interfere with the said fish. In that case say what is given to you to say. You wil! in due course acquire a certain reputation for aloofness, but your sport will improve.

The outside world is not much considered in fishing meditations. More or less dimly, however, cvery angler must from time to time be conscious of an alien impinging something which meets him at various points in his placid carecr, and which has on him effects of various kinds, according to his 
circumstances and his moods. No matter how single-eyed his devotion to the brave pastime, no matter how remote the solitudes to which he retires for its better prosecution, he can never wholly be free from the possibility of collision with this something, and it is just as well that he should realise the fact and be prepared to accept it.

It is not wise for a man to be betrayed into unseemly wrath, unless he has a reasonable prospect of carrying matters through with a high and heavy hand. Nor is it well for a man to add fuel to the foolish fire of mirth by obviously and ridiculously resenting the guffaws of the uninstructed. Nor should the discreet angler unguardedly permit himself, by some scruple of weak politeness or uncalculating good nature, to act on such advice as may at any moment be proffered by any stray comer. Nor should he suffer his strong mind to be unnerved by the glare of apparently stony and critical eyes directed upon his proceedings. Nor should hebut it is needless to tabulate the many things which are inadvisable. The main thing is that those mentioned and the others implied are all likely to come to a man to his undoing, unless he is prepared to meet emergencies and to suffer untowardness with some measure of philosophy, and even gladness.

For this something is widespread and pervading. You may meet it in curiously-topped stockings, 


\section{A PECK OF TROUBLES}

spats, and an eye-glass, near the source of a mountain-born streamlet; you may see it leaning, collarless and pipe in mouth, over the chalk stream bridge; you may hear it, loud-voiced and discordant, addressing you in many-tongued insult from the passing char-à-bane; it may take on a reverend and misleading guise, as with whiskers eloquent of a cathedral close and a hat from Messrs. Vanhecm and Wheeler; or it may disturb both your sport and your emotions by stcpping in white "tempestuous petticoats," and brandishing a white parasol along the marge of the erystal river; it may even appear as what Homer ealled "a shameless stone," hurled from a safe strategie position by some probable, but unidentificd, small boy. There are, in fact, endless ways in which the Public may come into touch with the patient men (if there be any patient enough), who read these lines, and are otherwise worthy to be called anglers.

Not all these ways are to be considered as altogether unfortunate, though. The saving grace of humour is spread over some of them, and often an ineident occurs which, rightly considered, should kecp a man happy for quite a long time. I remember one. It happened that at the end of the trout season three anglers, all famous in more ways than one, were sedately taking their homeward way from a famous fishery on the Itehen, thinking, I make no 
doubt, of dinner, the day's lack of sport, the weather, and such other things as have filled the minds of returning anglers since time immemorial. To them appeared a fourth, a member of the Public, whom I will make bold to conceal as Agricola, and some conversation took place by the side of what some call a carrier, others a drawn, others a ditch, others an eligible bit of fishing, two miles of it, one on each side.

Then to all four appeared a trout, which rose twice within tempting distance. A trout which rises twice when you are going home (according to my experience) is not a fish to be disregarded, and I am not a bit surprised that one of the anglers at once unlimbered for the attack. Nor, I must add, am I surprised that the attack ended abruptly in the flight of the trout--I know the carrier in which he lives, and if I have not known him, I have known several of his brothers. To continue, the trout was visible in the clear, shallow water, a rapidly diminishing form, and the anglers, recognising the inevitable, were for continuing their progress in the opposite direction.

Then Agricola rose to the occasion. Was he, a member of the Public, to suffer the unfortunate disciples of Walton to go away discomfited while he had legs to run and arms to wave? Not he. Like the intelligent sheep-dog of the mountain, he was after the trout to turn it in its tracks, and to 


\section{A PECK OF TROUBLES}

drive it back to the place whence it started, the place where an angler could casily cover it with a fly again. He ran, and as he ran he promised that he would do these things. And as he promised the anglers protested that his labour was in vain. Yet still he ran.

The story ends there, and I do not know whether the fish was caught, turned, and driven back. I imagine not. Certainly it did not resume its position, begin to rise again, and ultimately succumb to the blandishments of Greenwell's Glory or whatever the fly was. If that had happened, naturally the story would have had a long and ecstatic continuation, and I should have had to put it in another' chapter. As things are, I am not distracted by the intervention of miracles. And, indeed, it would be a miracle if any member of the Public by taking thought ever assisted the angler to catch a fish, because members of the Public are not so construeted as to understand the ways of fishes.

It is only necessary to reflect on some of the customs of the Public to realise this. How often have we not seen a worthy gentlcman, obviously possessed of all the qualifications for being a kind uncle and a good churchwarden, stop athwart our rising trout, stand at gaze for a while, and then make vigorous pointing motions with his walking-stick. How often have we not heard him say as he pointed: 
"There's a fine fish here," and, after a little, "It's gone away now." There are some of us even who have had the evil luck to be assisted by just such a good man in the landing of a fish. I once had to exercise considerable force and to strain a promising, though incipient, friendship in order that I might take the landing-net away from him. He had "jabbed" horribly three times, and I felt that the gut would not stand any more of it. Our parting was not so cordial as I could have wished, but I do not see what else could have been done, and, anyhow, I got the trout.

It is not so very long since I read in some provincial paper of a police-court case which arose out of the throwing of stones at a float. I cannot remember all the details, but the float was certainly fons et origo mali, and stones were thrown at it with intent. An affray followed because the justly incensed angler was not of the meek kind, and in the end the thrower was mulcted in a sum, to my thinking, scarcely proportionate to the gravity of his offence.

Stones, of course, represent a mood in the public mind quite different from the moods which provoke obvious information, unwanted advice, or unskilled assistance. Usually they are symptomatic of youth. Hardly any small boy is without the desire to throw a stone at a float. Even a small boy who is also 

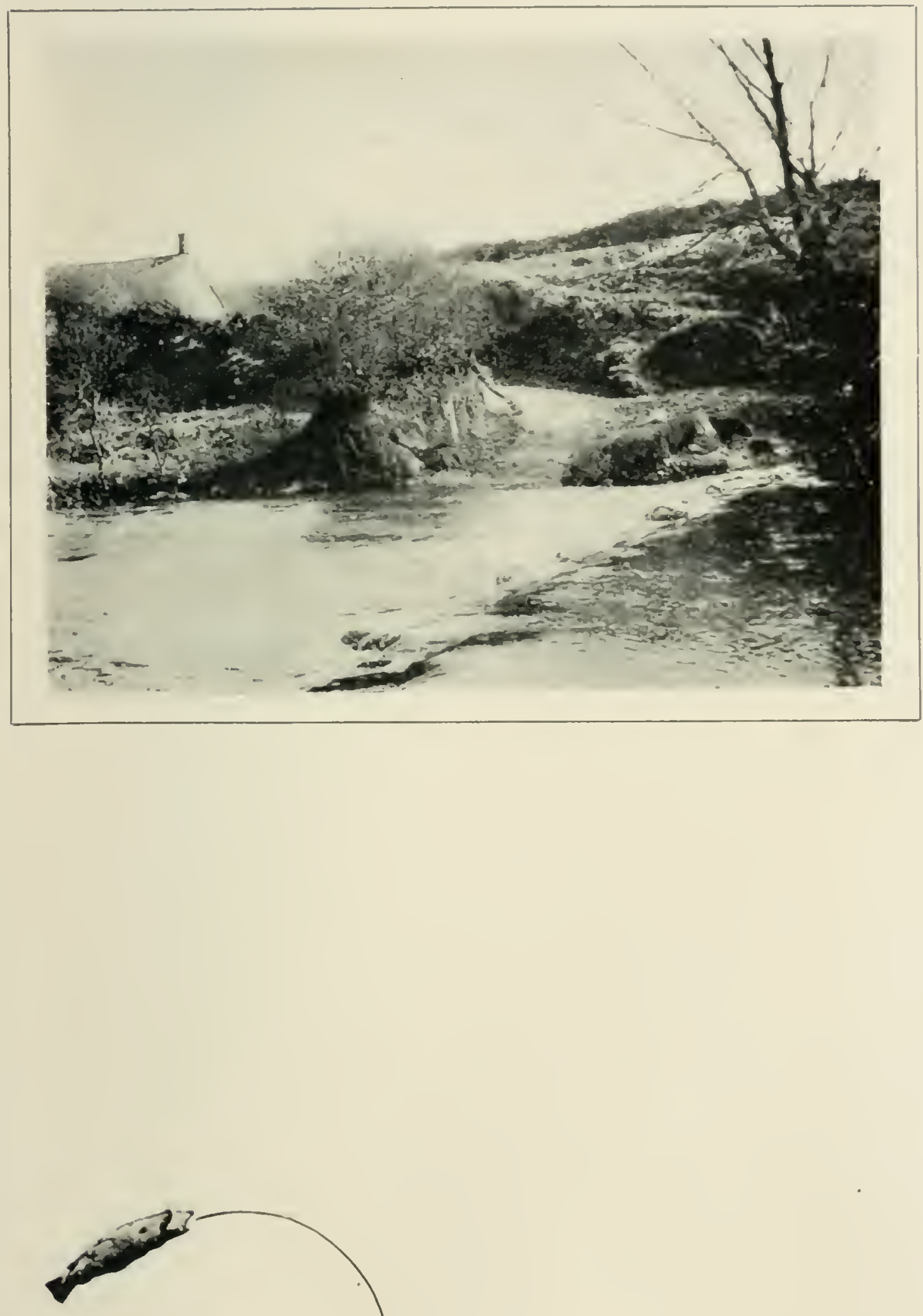

The Upper Exe 



\section{A PECK OF TROUBIES}

a fisherman may succumb to a sudden longing of this kind. Well do I remember an incident which occurred in my own youth, and in the contemporaneous youth of a now distinguished surgeon. We each had a float, and we were both overcome by the ballistic impulse at the same moment. Unhappily, we also went armed in those days, and the subsequent duel between air-gun and catapult was a sad affair. I can still fecl the shrewd smart of a marble which smites the calf of a stockinged leg, and I am sometimes reminded that the slug from an air-gun may inflict pain even less endurable. Let me now draw a veil over a scene of carnage.

Grown persons, I am glad to think, do not throw stones at anglers very much, except in out-of-theway places. In this respect manners must have mended somewhat. In his Fishing Catechism Colonel Meysey Thompson mentions an old rule in the code of a certain fishing chub, which ran : "Any one throwing stones at another's line will be severely dealt with by the committec." I am glad to think that such a rule is no longer wanted as between angler and angler. As between Public and angler, I don't think it is much wanted either, which is fortunate, because there would not secm to be much remedy for us save in dignified retreat or impetuous battle. And usually the Public is on the other side of the river when it does throw stones, so, unless 


\section{TROUT FISHING}

the angler ean throw more and bigger stones with better aim, battle is less admirable than flight.

But I have already said that the Public does not throw stones much, and generally I do not think it hostile to us. It is just a great alien thing, which is not unfriendly but simply does not understand. That is deplorable from one point of view, and it leads to troubles as I have said, but there are compensations. If the Public understood it would also angle, and where should we be then? It would be all troubles and no fish. 


\section{CHAPTER XIII}

\section{WEATHER AND WIND}

THE books of the rules at one time used to insist forcibly on the desirability of a cloudy day for trout fishing, and, indeed, some of then do so still. A theory in fishing, once it has taken hold of people's minds, takes a lot of uprooting, not, indeed, that it is intended here to suggest that the praise of grey skies is altogether mistaken. Doubtless there are conditions of drought and calm when they deserve all that can be said for them, especially if they bring the much-needed refreshment for the parched earth and shrunken streams. But without depreciating unduly the value of dull weather, it is certainly possible and right to maintain that a bright sun is not the foc to sport which some authoritics would have had us to believe, and that there are times when it is even necessary to successful trout fishing. You have only to consider the conditions of a normal spring to appreciate this. For days, perhaps wecks, the wind has been set in the north or east and skics have been hard and steely. If 
rain has fallen it has been first cousin to snow or sleet. The trout have been backward in condition and little inclined to rise, insect food being very scarce. Then comes a change of wind and a burst of warm sunshine. Even if there is no rain to speak of, the improvement in fishing is immediate, for flies appear and trout rise to them.

Looking back on past experiences, the angler does not find any lack of sunshine in the retrospect. It may be that we are more inclined, as is the sundial, to record the bright hours, and there have certainly been bits of sport enjoyed when the weather was far from delightful. But, for all that, it is obvious that a great many of our best days have been lived in the countenance and favour of a glorious sun. Big fish or big baskets-it does not matter-there is proof enough that the sun is no hindrance to achieving either ambition, while it is certain that it helps us to appreciate our luck much more keenly.

Once it is settled that sunshine is not bad for trout fishing, it becomes a matter of some interest to consider why anglers used to think that it was. Possibly the reason lies in the tackle they used. There must have been more difficulty in approaching trout in days when a very long rod was required for throwing even a moderately long line. And the old artificial flies were many of them crude productions of great size as compared with the little 
things we use to-day. Certainly they would show to better advantage when wind and weather combined to conceal their more prominent features. On south-country streams, at any rate, such patterns attached to coarse gut would not stand much chance on a calm day under a bright sun.

These are possible reasons for the old dislike for sunshine. But there is another thing worth considering. Possibly the old writers, like the new, did not know everything, and there may have been plenty of silent fishermen, as there are now, who went on their efficient way without heeding the rules laid down for them by the prophets. Experience is the best teacher after all, and probably at no time did experience ever say that grey was always to be preferred to gold.

On the whole, except in grievous droughts, I would always have it sunny when I go trout fishing, even though I may possibly suffer in basket thereby. One very definite reason which I have for this is that I dearly love to sec all that is to be secn, and more especially to see the fish which I am trying to catch. In some conditions, indeed, I feel as though I could not catch any without seeing them.

Take a rather dour river like the upper Kicnnet on a morning in July. The Mayfly has been over some time and there is little to bring the fish up to rise steadily before the evening. 'Then probably 
they will come on to blue-winged olives or sedges with much the same eagerness as the fish of Itchen or Test. But in the daytime there is considerably less visible activity in the Kennet than in either of the Hampshire streams. I believe that a good deal could be done to make it a " better-rising " river, but that is beside the present question.

The fact is, that on the Kennet in the dog-days you see little to fish for if you judge solely by rings on the surface. And yet you can catch trout, and good trout, in certain places if you give your mind to the business of hunting for them. I find it almost essential to have the help of strong sunlight and a fairly calm surface, because my aim is to spot the fish and to try and tempt them without necessarily having seen them rise. But here I may mention what seems to me an odd cireumstance. Supposing I sat on a seat with my rod spiked in the traditional manner and waited for rises to appear, hours might pass without any definite encouragement to make a cast. But if I prowl slowly along, find a fish lying quietly near the bank, and watch him, it is very probable that in a few minutes I shall see him tilt himself and take some floating trifle, or, which is even more likely, I shall see him turn and take something beneath the surface. What, I believe, it amounts to is that many fish in hot weather are feeding so quietly that from a little distance you 
would never detect any sign of movement. The trout that you stalk, therefore, may well be rising fish though you would not know it without actually seeing them. It is hardly necessary to dwell on the fascination of trying to catch such visible fish. To watch a big mouth opening and shutting on one's fly is a sensation of blissful terror.

Exactly the same kind of fishing is possible on wet-fly streams in certain conditions, of which low water is one. The still pools and flats always have a number of trout which cruise at the edge of the bushes or near the banks, and when the light is favourable you can sec and fish for them. But stalking them is not quite the same thing as stalking chalk stream fish. There is less movement about it. You get better results by standing still in a likely place than by patrolling the banks. For the trout themselves are moving, in and out, up and down, round and round, and sooner or later one, two, or even more will come into view. A single fly accurately delivered will generally get a rise from one of these fish, and I do not mind whether it floats or sinks. Some of the items which fall from bushes float, some probably sink, and the trout are ready for either procecding.

Sometimes, of course, the sun makes too much of himself for his most cordial admirer. There are days on which the heat in the open meadows is too 
great for any exertion, when the trout are dormant and even the little silvery grayling are too exhausted to splash about on the shallows in their peculiar and rather annoying manner. The big hatch-hole, where the great trout may usually be seen cruising, is a horrid sight, a vast bed of weeds going round and round like the dappled horses at a fair. Even the abstraet interest of speeulating why weeds can revolve for ever on an eddy without being swept into the main current, and so carried away downstream, yiclds at length to indignation that such things should be, to amazement that perfeet chalk stream fisheries should have the almost inevitable drawback of other people's weeds whenever one is privileged to visit them.

Lunch is eaten in melancholy, and the convietion of an impending blank grows more profound. Not a dun has been seen all the morning. Yesterday, in like weather, not a dun, or hardly a dun, was seen from morn till eve; the prospects of a rise of fish are remote, espeeially as each evening the sky is overeast with heavy masses of cloud, masses which threaten thunder, yet do not perform, masses which make the light bad and the fishing hopeless. The effect of meditation on a bad day is not conducive to energy, but all is not yet lost. The other side of the river, perhaps, might diselose a fish smutting close to the bank. A path runs aeross the sluice- 
gate bridge, through a bed of withies (in each of which the aggravating rod manages to entangle itself), and so to a plank across a carricr. Up this the cyc travels, for it is a plcasant sight on such a day, its water being cool, clear, and, above all, shaded. Happy thought! Why not follow it up? There must be trout in it, for all such streamlets in a chalk stream country hold trout, if only they are permanent and not mere ehanncls of temporary irrigation. 'Trout or no, one thing is certain; this little trec-shaded rush-girt brook is the coolest place within miles, and that alone is indueement enough to explore on such a day.

There are some signs of fish, too. Waves in all directions prove it, waves caused by the appearance of the angler's head over the rushes at the first corner. The advance was most cautious, too, with nothing sudden about it. If you want to look for a trout, you must move very slowly, and the rule was earefully observed, yet there are the waves to show failure. All, there is a fish! Its forked tail and slim shape show it to be a dace, which explains matters. Dace in the first place have bad consciences, and in the sceond swim in companies, which makes them harder to approach in such a small stream than trout. Many pairs of eyes give them an advantage. Once disturbed, however, they are not necessarily uneatchable as a trout 
would be; if you keep still, they will generally return in two or three minutes, and then you can catch one as though they had never been frightened at all. A trout, on the other hand, takes disturbance hardly, except in waters where he is accustomed to human beings. There he will hasten away, and return almost at once. In streams where he hardly ever sees a man, the sight of such a thing gives him a serious panie, and he will very likely appear no more for hours.

Proof of this is afforded presently. After several bends and corners have been explored without the sight of anything but a few more dace, a bold, spreading rise is observed under some bushes at the head of a long, straight reach, and between an island of rushes and the far bank. Nearer inspection reveals the cause, a fine trout which comes out from under a bush, takes some invisible fly and retires to his holt. By reason of obstructions there is only one way of covering him properly, and that is to take to the water, wade cautiously up behind the rushes, and then to switch a short line under the bush. This manœuvre is effected with the utmost care-it takes some ten minutes-and, behold, the trout has fled! He must have seen something, despite all precautions, and a long wait neither reveals whither he has gone nor brings him back. The angler goes on sadder, but not much wiser; he does not see how he could have 
been more like the proverbial Red Indian. A little higher up is observed a tiny rise, evidently from a dace. But, no, as it is repeated, there is a slight disturbanec below the dimple, which shows that the fish's tail is a long way from its nose. Obviously this is a trout, and a good onc.

Again there is a slow, stealthy deseent into the stream, and knee-deep the angler waits, hardly daring to draw breath, for the rise to be repeated. The spot where the fish lies is flecked with sunlight, which finds its way through the interlacing twigs of the bushes on the bank, and if there is a movement one ought to be able to see-confound it all, onc can sce, and the beast is but a small onc after all, barely three-quarters of a pound from the look of his back. Never mind, after all this trouble, have at him. The Welshman's button drops just above, a gentle rise is followed by a slow strike, andby Jove, it is not a little one after all. The indignant swirl shows that he is a fine fellow. Bushes to left, roots of a stump to right, weeds above, and bushes below, there is only one way of playing a heavy trout on light gut here-with a light hand. Whenever he gets near danger, ease the pressure; whenever he wants his head coax him back. It takes time, but it secures a fish which, with the least rough treatment, would bolt like a runaway horse, and smash you all to pieces. At last the 
angler steps out on to the bank with a beauty, all red, brown, and gold, in the meshes of the net. Ah, a pound and three-quarters good weight, and so home to tea well eontent!

The sun has his advantages even when there is too much of him, if he drives the angler to the shady plaees and so promotes sport of this thoroughly attractive kind.

The late Mr. F. G. Aflalo, whose premature death has recently been so much deplored by all honest anglers, once compiled a very interesting book called Fishermen's Weather. In it he assembled the views of a large number of prominent anglers on the affect of various kinds of weather on their sport.

I am not sure that anything very definite in the way of precept emerged from all that mass of evidence. How should it indeed? For the ordinary angler's invariable rule is, and from the nature of things must be, "Fish on and hope for the best." The colleetion of data may affeet the intensity of his hope, aceording as it indicates favourable conditions or unfavourable, but it will hardly affect the question whether he fishes or not. If accumulated experience says, "You will have very little sport," he will probably retort, "There is always an off-chanee."

As indeed there is, especially in trout fishing. I have pretty definite ideas as to the effect of eertain kinds of weather on some other fish-for instance, 
I am convinced that a big drop in the barometer with the approach of heavy rain or wind, or both, is very bad for pike fishing-but I have no settled convictions in regard to trout. They seem to me less affected by weather, and even by violent ehanges than any other fresh-water fish, and I never saw a day yet which I should honestly deseribe as hopeless, except by reason of the water being too thick or flooded for fishing. There are very bad days, of course, on which you cannot expect to catch much, but there are no days on which you may not hope to eatch somcthing.

Extremes of heat or cold, days of thundery depression or of bad light owing to the east-wind "glare "-these seem to be the worst in themselves, and the day of bad light is at the bottom of the list. Rain, whether steady or intermittent, is unpleasant for the angler, but it is not necessarily hostile to his sport. Some of the best hatehes of fly I have ever seen have occurred on very wet days. I remember one Mayfly day whose morning soaked me to the skin through mackintosh and everything. I changed at lunch time, borrowed more mackintoshes, and fared forth again to find the rain as hard as ever. But early in the afternoon the fly came on and the trout began to rise 'with a heartiness that I have never seen surpassed. Every fish which I covered took my fly properly. Cireumstances over which 
I had insufficient control-such as nerves, hand and so on-combined to make the basket unimpressive in relation to the opportunities. But that was not the fault of the weather or the fish.

I do not like fishing in heavy rain, but that is not because $I$ expeet to find the trout out of humour. I have seen such brave doings in spite of rain that on the whole I am surprised if there is not a good rise at some time on the wettest day. It is mere human weakness that makes me prefer a dry jacket even if the rise is not quite so good.

Even more does human weakness prejudice me against wind. Frankly, I hate wind when I am trout fishing, in spite of the fact that, like rain, it seems sometimes to induce a good hatch of fly and consequently a rise of fish. Often, I must admit, the wind is really no great matter, though it has great power to annoy. The gusty puffs which wreck an occasional delivery, crack off a fly here and there, or cause the gut-cast to wrap itself round the rod now and again-these, though a stimulus to what is pleasantly called "langwidge," in very old as well as in new spelling-these puffs can be endured. They colour, but they need not destroy, a day's fishing. Once a foolish fish, or an exhibition of fancied skill, has improved the mental condition, the puffs have to a large extent lost their power to madden. Recovered sanity makes it plain that a 
breath of wind more or less does not ruin one's sport, and one learns to wateh the grass or the reeds for signs of an approaching gust. Eventually one becomes quitc complacent and satisfied. Cheating and beating the wind is after all not a fiction of the poets. It is more than that-an actual possibility. It is morc even than that-an accomplished fact. An excellent demonstration has been going on all day, had any learner been there to benefit by it. But there are two and a half brace of eloquent, though silent, witnesses.

And so a dry-fly man, after a time of casy airs, may come to believe himself in truth able to captain his soul against any wind that blows. "My dear fellow," he will say, "it's all a question of management. Slowly does it. Don't hurry, and don't forget the downward cut." And he will say, "Oh, I don't much bother about wind. I've got a powerful rod and a heavy line." And he will smile the sort of smile that he conceives Marryat to have worn when consulted about the first beginnings of knowledge.

Then, without warning, comes the day of annihilation. It is often a deceptive sort of day, breaking fair, and showing adequate patches of bluc amid the heavy clouds that roll up, and on, towards noon. From the haven among the trees and backed by the hill one would at starting be prepared to assert 
that the day was going to be calm, or at worst no more violent than may be managed by the skill already mentioned. But when the river is reached, such fond imaginings have to yield to solid and unpleasant fact. The wind is much more than a rustle among tree-tops. It is a potent reality, which makes the dry-fly man clutch his hat and debate within him whither he shall go for shelter, so that he may find a quiet streteh of water where flies and rises shall be visible, and where it may be possible to cast without having to put out all the skill which is in him. Of course, it would be possible to fish in the exposed parts, for a man who knows his business; but still, the bow should not always be bent, and it is wise to reserve some measure of strength.

Accordingly search is made for the quiet place desired. Just below the bridge-that is the spotand steps are taken thither. But on actual trial the place is not so sheltered as it scems. True, the water is not lashed into foam as lower down, and two or three rises ean be seen on the broad shallow, but when it comes to eovering them, the line is taken by a sort of whirlwind and deposited suddenly and foreibly on the bank, the gut being eoiled ingeniously in and out of the herbage, so that it needs patient disentangling. Nothing daunted, though possibly a little surprised, the angler tries again, putting 
more power into the cast. This time there is a lull in the wind, and the line comes upon the water like a flail, putting two of the rising trout down at its one fell swoop. Then follows another struggle with the herbage, and then a third rising fish is put down, and lastly the fly hits the top of the rod with a crack, which suggests that both must be broken. After this the angler wonders whether conditions would not be better on the other bank, where the trees are, and he goes round to sec.

They are not better, only different. It proves that on this side the wind comes straight down on the water and then rebounds upwards. On its first rebound it takes east and fly with it into the maze of young greenery, and there they remain probably till autumn does her benefieent work of decay. The angler goes away from the bridge, and starts on his pilgrimage in search of calm. Up, down, backwards, forwards, round, behind, in front-there is no peace anywhere. The wind is all-embracing, all-compelling. It absolutely fills the whole of that valley, and no nook or corner is safe from it. And everywhere it is resolutely set with its face downstream.

What is the result? The dry-fly man struggles on desperately till lineh time, and with despairing eye watches the morning rise gradually petering out into oceasional belated splashes from yearlings, 
which are quite useless to him. At last, with fury in his heart and emptiness in his basket, he eats his wretched sandwiches, sips from his inadequate flask, and spends seven matches in the task of pipelighting. Then he rises in his might, puts on a big March brown or an alder, and becomes a wet-fly man. It is sad to have to tell it, but for the rest of the afternoon he "rakes" away downstream in the most abandoned fashion.

It is more cheering to finish the tale-it is really a true history of a real day's angling. After some hours of raking, the angler desists and retires. And his summary of the day's sport given to a kind inquirer is: "No, not a good day. A few little things returned, that's all." "Brother," said Mr. Petulengro, "there's the wind on the heath." "Brother," I would reply, "by all means. And let it stay there. We don't want it on the river."

We get it on the river, of course, in full measure, as we get so many other unpleasant things that make up what we call our weather. But we go on fishing all the same. So it is not much use complaining. And every now and then we get one of those perfect days which make all the rest worth while. So we have nothing really to complain about. 


\section{CHAPTER XIV}

NEW WATERS

TuE chicf need of the trout fisher nowadays is more trout fishing, especially in the neighbourhood of the big centres of population, or at any rate within possible reach of them. It is daily becoming more difficult for the ordinary man to get any sport worth mentioning without going a long way for it, and without paying a good deal of money into the bargain. As for rights of fishing on the famous south-country streams such as the Test and Itchen, they are almost out of the question execpt for the wealthy. And even rich men may be heard lamenting that they cannot get a bit of chalk stream for love or money.

If you go further afield you can get fishing cnough. The hill-distriets of Great Britain are mostly well supplied with trout streams, and in some parts there are lakes which add to the opportunities. Also in those districts there are quite good facilitics for the stranger who turns up with a rod. Association or hotel waters give him considerable seope.

The fishing of the hill-distriets is, however, for 
the most part, a matter of the wet fly and of small trout, and though it has points of superiority to other fishing, it does not satisfy all cravings. The man who has once known the pride of a threequarter-pound average weight will always yearn to repeat the experience from time to time, even though he enjoys the five-to-the-pound day as keenly as ever. It is, in fact, the bigger trout which are hard to come by, and this is chiefly for geographical reasons. The streams which naturally produce them in abundance lie, for the most part, near great cities and especially near London. Therefore they have become highly valuable and much prized. It is a significant fact that for many years the only part of the Itchen on which it has been possible to get day tickets has been the short length at Winchester known as "Chalkley's," while on the Test, so far as I know, it is not possible to get a day ticket anywhere. The other chalk streams are hardly more hospitable to the casual fisherman. The Chess and other Buckinghamshire and Hertfordshire rivers, the Meon, Hamble, Whitewater, Lyde, Wylye, Frome, Avon-as trout streams, these and others like them are practically elosed to the public. There are some small facilities on the Kennet, and on the Gloucestershire Coln, but generally speaking there is no public fishing in any of our southern waters which rise in the chalk 
and which are famous for their trout. A man has to travel to Derbyshire before he gets anything like a good cxtent of available water producing fish bigger than those of the ordinary mountain streams. This is a melancholy story, and it is not easy to see how the situation may be bettered so far as the chief trout strcams are concerned. It has always been a matter of surprise to me that some enterprising person has not taken a good length of one of the best chalk streams with the definite object of making a ticket-water of it. As an annexe to an hotel I should have thought it could be made to pay handsomely. The thing has not been done so I suppose it has not secmed a suffieiently safe venture.

Though we may have to rule out the famous streams from our imaginings of a world better found in trout fishing, I do not think we need therefore give up hope of improvement. There is much water in England which is undeveloped and which might be made quite productive if it was taken seriously in hand. There is much land which eould be turned into water with a little engineering skill, some labour, and a certain amount of expense, land at prescnt of small value for any agricultural purpose except as very rough grazing. A survey of the more southerly counties would, I am sure, suggest a surprising wealth of possibilitics. 
Of course there are many difficulties to be overcome. Pollution has played the mischief in some districts; in others the available waters are already oceupied by coarse fish; in others the rumour of an extant trout is enough to rouse the neighbourhood with all its lethal weapons ready for the prodigy's destruction. But nearly all difficulties can be dealt with by perseverance and ingenuity. Pollution could in many cases be abated by amicable arrangement. In regard to coarse fish, a working compromise could be reached-it is not impossible for good trout to co-exist with numbers of coarse fish so long as the water suits them; and destructive neighbourhoods could doubtless be educated to higher standards by improved opportunities. The existence of one trout per mile invites counsels of despair such as guns or night-lines. But the appearance of many trout would turn men's thoughts to flies.

I have scen some interesting and hopeful experiments in making trout fishing out of nothing more or less, and I am sure that much more might be done in this way. It needs co-operation and it calls for patience. Anglers must learn to look forward to a rather distant future if they are seeking to put a new trout fishery on an established footing. It takes two or three years for young trout to grow to a good size and to start breeding properly, and 
it is the breeding that one most hopes for. Once it has come about that a stream can cvery year show a certain number of indigenous fry, it may be assumed that everything is going well. Artificial stocking may still perhaps be carried on with advantage if there is a good deal of fishing, but one has the comfortable assurance that the new fish, if they survive the rods, will settle down as useful naturalised citizens of the community into which they have come.

One of the most interesting expcriments in making a trout stream which I have had the opportunity of studying was carricd out on a little river in the Home Counties a few years ago. It was one of those neglected waters which had been given over to small coarse fish, probably because no one ever thought it would be fit for anything else. A group of friends, however, had the luck to stumble on it as they stepped out of London (so to speak) one day, cast a discriminating cye upon it, and divined that though then practically derelict it was capable of serving worthy purposes, among them that of supplying hard-worked people with trout fishing at a very small outlay of time in travelling. Doubtless they were influeneed by the fact that the brook -it is little more than that-ran through a delightful valley of its own, with downs swclling up on either side, and with plenty of boskage all about 
to eut off the view of a world which is always too much with us inside the forty-mile radius. Doubtless, also, they found that the streamlet, albeit not strictly belonging to the ehalk, was pretty well and constantly supplied with water, which is no small matter in the history of a river. Perhaps, too, there were traditions which told of trouting there in the past.

This, indeed, was my first thought as I surveyed the stream while I put my tackle together. "Surely," I said to the kecper, "there were some big trout here before?" "Well," he replied, "when we netted the pool below the mill we only got two, besides the dace and things." "And were they big?" I asked. "About eight or nine inches," was the answer. Which scemed pretty conclusive, for if there be big trout anywhere, obviously the place in which to find them is the pool below a mill.

So it was reasonable to assume that when taken in hand the stream was in no sense a trout water, though the existence of a small one here and there argued that it should be capable of that development. And the sequel proved the justice of the contention. The discovery resulted in the formation of a little club, in a spell of intensive water culture, and in the ultimate creation of as delightful a little trout stream as soul could desire. Within 
the limits of the fishery, some three miles perhaps, I found every type of water-brattling shallows, deep, swirling holes, ripples under tree roots, dry-fly glides, and also some of that almost dead water, where trout cruise round and round and give the angler such fascinating problems as to getting his fly to the right spot at the right moment. All through there was every indication of really intelligent management, as might be expected of an enterprise undertaken by experts, and it was evident that the right weeds were being encouraged, that mud had been sedulously removed, and that the stream had been coaxed into its most suitable channels-even a little brook running through pretty "stiff" country is liable to make mistakes of direction. An accumulation of mud, for instance, may casily divert the flow from one side, where bushes offer good cover to the fish, to the other, where there is no such advantage. Good kecpering is not unmindful of such things as that.

What of the fish? Well, I came upon them on a very bright day after a sharp night frost, and right at the end of the season, and I hardly expected to do anything at all, having been warned that the brook was not a chalk stream. On that account I did not hope for anything of a hatch of fly in the daytime. The time of the brief evening rise, moreover, would see me hurrying to the station to begin a 
return journey across country which would be the reverse of brief. Circumstances, therefore, were not favourable. And yet I had very good sport, thanks partly to a decided hatch of fly which came on in the afternoon, and partly to the eagle eye of my friend the keeper, which was very swift to mark a real rise, and availed much in preventing me from wasting effort over water-rats and other interesting but irrelevant phenomena. In all I landed three and a half brace of pretty little fish running from about ten inches up to fourteen inches, keeping a brace and a half of the bigger ones for breakfast purposes. I had also the satisfaction of slaying three small chub, remnants of the former population of the stream.

The trout had, of course, been turned in either that year or the year before (though I saw a few tiny ones on the shallows that were probably the result of the last winter's spawning), and so were open to the imputation of bcing stock fish. But they had none of the silliness characteristic of typical stock fish. The influence of a company of very clever anglers may be calculated on to eradicate silliness before the end of a season, especially when many trout are returned to grow wiser and better. Lest I should have any doubt on this point (having a brace and a half in the basket), the keeper led me to a corner where there was a persistent riser whom 
he called Jones. He insisted on my angling for Jones, and smiled when, after a considerable time, I told him that angling for Jones had no interest for me. And on our return journey an hour later he said, "Better have another cast at Jones, sir. He's still rising." But I told him the truth. I was not man enough for Jones, or he was too much of a trout for me.

There was another fish, too-Robinson hight, I think. His story is not without humour. Quite early in the afternoon the keeper had been telling me of the many attainments of the fish on the upper water. "There is one," he said, "whom we eall Robinson, and he won't let you get within forty yards of him." I put this fact away in my mind, and thought no morc of it till about half-past four. Then it recurred to me. From the distance we had seen many rings oft repeated. "There's one," said the kecper with much eagerness, and he intimated that if I wanted to make up my two brace now was the time. Needless to say I at onee made ready to eover the trout, and crept up to within easting distance. After waiting there for some minutes I looked round. "Is that the trout that won't let you get within forty yards?" I asked. "Is that, in fact, Robinson?" And a smiling face assured me that it was.

That little strcam still goes on successfully after 
several years, though I believe it knew trouble incidental to the later years of the War (it was not alone in that), and it may be cited as a satisfactory example of what can be done. I am quite sure that its story could also be told of other small streams if they were treated in a similar manner. It is important to realise that its improvement does not only consist in the introduction of trout, but also in the establishment of a good show of fly, both duns and sedges. This is presumably due in part to the introduction of suitable weeds, of which I believe good store was brought from the Itchen.

Another experiment in the creation of trout fishing which is of interest is the making of a fishery by what may be called force majeure. The Thorney Weir water at West Drayton has afforded the most notable instanee of this. The Colne used in old days to be one of the finest trout livers in the south of England. What it was like is shown by the chapter in Sir Humphry Davy's Salmonia which describes Mayfly fishing at Denham. But there has been a sad falling off since then. During the twenty years or so that I have known it myself I should never have described it as a trout stream, though it has always held a certain number of trout. Latterly it seems obvious that abstraction of water combined with a good deal of pollution has made the chances of trout worse than ever. The prob- 
ability is that though older fish may contrive to get along well enough in some parts of it, the ova and fry stand a poor chance. A big head of coarse fish naturally adds to their difficulties.

The experiments at Thorney Weir were based on the theory that to get trout fishing on a big scale it must be, so to say, ready-made, and as a result a sort of tour de force was accomplished. Mudding was performed on an extensive scale and gravel was laid down in places. And then stocking was carried out in the grand manner. In the first year over two thousand big trout were released. Seven hundred of them weighed from three pounds to about four and a half pounds and many others were from fourteen to sixteen inches in length. In later years this colossal business was repeated and even bigger fish were turned in-up to seven pounds or more.

The result, of course, was remarkable fishingafter its kind-and the weckly reports contained lists of monsters, all captured on the dry fly. The trout fishing had eertainly been "made" successfully. The work was interfered with by the War and at last it became impossible to get big stock fish from the hatcheries, so the Thorney Weir fishing is, as I write, marking time. I understand, however, that the present owner intends to re-establish it as soon as conditions permit. 
The prejudice against big hand-fed trout that undoubtedly exists may lead many people to question the value of such stocking when it has been done. It must be conceded that the whole business is artificial, which is against it. But there is a great deal to be said on the other side in this instance. In the first place, by no other plan could the fishery have been turned into a heavily-stocked trout water at once; possibly by no other plan could it have been turned into a heavily-stocked trout water at all. Further, the water is only half an hour away from London, and it is obvious that even artificial trout fishing within such casy reach is a very valuable thing. The fact that practically all the rods available were taken up at once shows that the opportunity was keenly appreciated. When you have a water on the Test which is capable of growing trout casily, quickly, and naturally to a large size, the big deteriorating stock fish is almost certainly a mistake; but the Colne, with its long tradition of coarse fish, is in a very different category at present.

I had one or two opportunities of observing the results in different years and was not so impressed with the idea of fishing for tame fish as I expected to be. They were rather casier to catch than wild fish, perhaps, but not much. Anyhow I failed dismally to allure any of the monsters, and I came 
to the conclusion that even the most artificial of trout very soon acquirc a sense of diserimination. A few weeks of hard fishing will teach them a lot about the ways of the world.

There was one feature about the stocking at Thorney Weir which struck me as worth noting for other places. When all the big fish were first turned in they were not left to fend for themselves but received a daily allowance of artificial food. This allowance, liberal to begin with, was gradually decreased, the idea being that as the fish became accustomed to their new quarters they would make more and more use of the food-supplies they found there and so would be less dependant on handfeeding. I believe the theory worked out all right in practice.

It is hardly to be expected that there can bc many attempts to emulate the Thorney Weir proccedings-the expense would be prohibitive for most people-but I think the lesson of artificialfeeding gradually redueed is a useful one. I have more than once found that hatchery trout of considerably less size (say ten to twelve inches) take a long time to get acclimatised to a vater and to begin to put on weight. I think this must be due to the abrupt cessation of their aceustomed food-supplies. Where the thing is possible I belicve it would make a great deal of difference if they were 
hand-fed for a time and weaned gradually, say in about six weeks. Then they should not receive the eheek to their growth which must result from a temporary loss of condition.

Of course the ideal fish for stocking are trout which have never had any artificial food at all, or at any rate not since they were fry. But they are very hard to get and are naturally expensive, as they require so much more pond space in a fishery. The fortunate owner of a trout stream which runs in several channels, as do some of the chalk rivers, can get the desired result by turning fry or small yearlings into one of his carriers and transferring them to the main river when they are big enough. Something can also be done in a river itself by screening off an area of shallows, but this has its drawbacks. The screens must be cleared frequently and a flood will probably upset the whole arrangement. For most people, however, hand-fed stock fish are a necessity and therefore the question of carrying on the feeding for a time is important.

The other method of ereating trout fishing is the one suggested by the success of Ravensthorpe, Blagdon, and other artificial lakes. This, on anything like a big scale, is a costly business, but in a small way it should be within the scope of some landowners, and I expect that the future will see a considerable increase in the number of artificial 
trout watcrs. Such a fishery as that of the Enton Fly Fishing Club in Surrey encourages similar schemes elsewherc. Engincering difficulties apart, it seems such a simple matter to dam a small valley and so to cover a few acres of land permanently with water that the proceeding must commend itsclf, especially as trout grow very well on such submerged land.

The chief thing to aim at in the management of such fisheries is, I imagine, ensuring a periodical lowering of part of the water so that the land may be dry for a time. Then with a renewal of rich vegetation it seems to renew its power of fattening the fish. If such an alteration of levels is not feasible probably the best policy is to ensure a strong growth of useful water plants, and the stock of food which they promote, before any fish are put into the water. Then they are less likely to deteriorate after this initial rapidity of development. One more safeguard has always seemed to me very desirable, the sereening-off of certain shallow areas as food nurscries. If larvæ, shrimps, snails, ctc., have sanctuaries into which the fish, or at any rate the bigger fish, cannot pursue them, they will increase very rapidly, and so the rest of the water will always receive the surplus stock as it spreads beyond the borders of the protected areas.

Though there is, as I have said, not enough trout 


\section{TROUT FISHING}

fishing to go round at present, I believe it rests with trout fishers to make more, and it can be done in the ways suggested. The secret, for anglers of small means, is co-operation and hard work intelligently applied. 


\section{CHAPTER XV \\ ODDS AND ENDS}

IT is, when you come to think of it, rather odd that on some fisheries the standard of retainable trout is one of weight, while on others it is one of length. Would it not be better if clubs and fishery owners all had a lengtl standard? Supposing you have a standard of one pound and catch a fish of fifteen and three-quarter ounces or sixtcen and a quarter ounces, you could not venture to retain it (nor would you lightly return it) without first ascertaining whether it really reached the lawful pound. That would mean weighing it, and that would mean a great deal of unnecessary handling and messing about which is not good for the fish if it proves to be below the specified weight.

There may be ways of attaching the hook of a spring balance to a trout which are unobjectionable (if it is going back into the water), but I do not know them. The best, I suppose, is just to hang the trout on the balance by the gill cover, but if the fish gives a kick when hanging a serious wound to the gills may be the result. If it has been out of the water 
long enough to have no kick left in it, when you return it you will have to nurse it back to life, a tedious process to yourself and also probably not too good for the trout. To have been half suffocated cannot have a beneficial effect on any living creature.

If you must weigh a fish, the best plan is to do so in a wet duster, having previously ascertained the weight of the duster. Or, of course, it would be possible to construct a little weighing net with two strips of wire and a piece of muslin. This would be a useful thing to carry, and would take up no space. The landing-net might be employed, but if your spring balance only registers up to some four pounds, it would in some cases prove too heavy. Whatever your receptacle, it should not weigh more than a few ounces. One thing, however, is certain, and that is that a fish which may have to be returned ought not to be attached directly to a spring balance, and probably a good deal of harm has been done where such a custom is in vogue.

It is obviously better to have a length standard, and either to carry a measure or have one marked on the landing-net handle. The moment a fish is on the grass you can measure it and decide at once whether it is sizeable or not, in the latter case slipping it back into the water without delay. The only objection to the length standard that I can see is in the case of ill-conditioned fish which do not 
weigh as much as they ought. In the carly part of the season, of course, such trout ought to be returned. Possibly it would be practicable to have a girth and length formula. With a tape measure it would take very little time to asecrtain both dimensions. But as a rule the length measurement ought to suffice. The weight of trout varies in different loealities, but on the chalk streams the following scalc should be approximately correct : 11 in., 8 oz. to $10 \mathrm{oz}$; 12 in., $10 \mathrm{oz}$. to $12 \mathrm{oz}$; 13 in., 13 oz. to 16 oz.; 14 in., 1 lb. 1 oz. to 1 lb. 4 oz.; 15 in., 1 lb. 4 oz. to $1 \frac{1}{2} \mathrm{lb}$; 16 in., $1 \frac{1}{2} \mathrm{lb}$. to $1 \frac{3}{4} \mathrm{lb}$. Well-fed fish from such streams ought always to be nearer the higher weights given, and, of course, now and then they are much above them. The late Mr. Halford in one of his books mentions a Wandle trout fiftecn inches long which weighed three pounds two ounees, but that must have been a sort of freak, even among the old Wandle trout, which were very heavy for their length.

It is, I think, worth while laying some stress on the fact that a good deal of harm is done to undersized trout which have to be returned by inexpert handling. Some men never seem to acquire the knack of holding a fish gently and yet with that even pressure of all the fingers which ensures a sufficient grasp. Nothing like a "clutch" is ever" required. The thing to aim at is to poise the fish 
at the point of balance, the fingers serving as little more than supports. It seems to me that there must be some affinity between the correct method of holding a trout out of the water and the delicate manipulation of the sportsman who smears his arm with clay and embarks on the business of "tickling" one under water. Anyhow I am sure that when held properly a fish even out of the water will struggle comparatively little, and this makes a lot of difference in the heartiness with which it resumes life when returned.

Sometimes, in hot weather or after a long fight, a returned trout shows no heartiness, but rather a pessimistic tendency to lie on its back and give up all attempts to live. In that case it must be coaxed by being held in the proper position with its head upstream until it decides that life is worth while after all. In obstinate cases a gentle movement backwards and forwards in the water seems to stimulate the action of the gills, but as a rule it is enough to hold the trout in the proper position for a minute or two. If time is precious, as when the big fish have just begun to feed properly on the Mayfly, first aid can be given by propping the sufferer up against the bank with a bit of stick which is stuck into the bed of the stream.

This matter of returning fish has provoked a good deal of discussion on account of its presumed 
results on the fishing. The contention is that too much returning makes trout bad risers and that the sport suffers by a large proportion of the older fish being abnormally suspicious. There may be something in this, but I do not think it a very serious risk. Fish have not long memories and I doubt if the sense of perils past lasts through the close time into a new season. A grave objection to returning fish is the possible physical effects of mishandling. This will almost ecrtainly affect the condition of the trout, interfere with that good digestion which is necessary to their growth, and so prevent their becoming sizeable in the normal time. I suspect that some of the lanky, ill-conditioned creatures which are found in our rivers are fish which have been injured in this way.

While one admits that returning trout may have bad results, it is difficult to see what alternative there is, at any rate for waters which are much fished and where the stock is not practically unlimited. A suggestion that anglers should keep everything they catch would plainly be impracticable. The best policy scems to be to adopt the length rather than the weight standard, and to add, if possible, a few precepts to the rules, one being that where a rising fish is plainly undersized (on the dry-fly rivers, at least, this is generally pretty obvious), the angler should refrain from casting to it, and 
another that due care should be taken in unhooking and handling any trout which is not to be kept. Perhaps a third might be that it is undesirable to fish consciously for trout which have recently been turned in, even though they do not come quite within the category of small ones. Where a sizelimit is, say, twelre inches and the new stock fish run up to eleven inehes, the temptation to see sizcable trout rising everywhere is considerable. It may perhaps be considered absurd to suggest differentiation between a stock fish of eleven inches and an old inhabitant of about the same size, but the feat is not difficult really while the stock fish are new to the water, which is the period that matters. There is no mistaking their splashy and "unfinished" way of rising after one has studied it a little. I admit, however, that abstinence may be a hard doctrine. The stock fish will display themselves when no other fish are rising and the angler always hopes for the best!

Trout are worth careful treatment while they are alive, and they are also worth careful treatment when they are dead-death by the way should be administered promptly when the fish has been landed, before even the fly has been extracted. Two or three smart taps on the back of the head, given with a small weighted stick or even the end of a spring balance, will do what is required -as they are, 
in a manner of speaking, valuable property, and even though their captor may not appreciate their flavour himself, there are numberless people to whom they would come as a real treat, perhaps a greater treat than salmon. Though trout make their appearance in the market, they are not so essentially a feature of the stalls or slabs as their larger cousins, and the sale of trout, luckily for our waters, is a relatively small affair.

The angler should always treat his fish with respect after he has caught them so that their edible value may not be in any way lessened. Probably the best method of treating them after they have been killed is to wrap them in a dry cloth. Paper is, however, equally good as a covering and will serve quite well if the eloth has been forgotten. Some men carry a linen bag to hold their fish, which is a good plan. Failing either cloth or paper, the creel may be lined with rushes, and more rushes may be sprinkled over the fish, or a dockleaf or two will scrve to keep them cool and protect them from a hot sun. Grass seems to be very bad for fish, which is a pity, as it shows them off to advantage. Hay would be better if it is easily to be got, the main thing being to keep the trout dry as well as cool.

In very hot weather the angler would be well advised to elcan his fish at once, if he can bring himself to do so. It is in the stomach that decom- 
position first starts, so it is obvious that if the intestines be removed the fish will keep fresh considerably longer. The trouble of course is that most anglers do not like to spoil the look of their trophies so soon, especially if they expect to have to display them to admiring eyes later. Cleaning fish is rather a messy job, which consorts but ill with the poetical side of fly fishing though it enables the fisherman to investigate the food which has been taken--a proceeding recommended by some experts. In any case, however, the trout should be cleaned before they are sent by post or rail to friends, and their chanees are improved if a little salt or vinegar be sprinkled inside, especially along the backbone.

Different anglers, of course, have different ideas as to the receptacle which is most comfortable for carrying fish. It is not easy to improve on the ordinary wicker creel so far as efficiency goes. It admits of ventilation, does not crush its contents, and does not get unduly hot. The only things against it are its sizc, shape, and weight. It is certainly not the most comfortable thing in the world to carry, though it is greatly improved by a combined waist and shoulder strap which eases the shoulder of a lot of weight. The ordinary waterproof partitioned fishing bag is more comfortable than the creel, and it is very convenient for carrying impedimenta as well as fish, but it is 
apt to be rather heavy. Also in the height of summer it must be a very hot abiding place for such delicate flesh as that of the trout. The bag is exeellent for winter fishing and the colder days of spring and autumn, but it leaves a good deal to be desired in summer so far as keeping the fish in good condition goes.

It sometimes happens that the simplest things are also the best, and this oecurred to me when I first saw a friend equipped with the light rush basket which fishmongers call a "frail " or "bass." There ean be nothing better for fish than this, as long commercial usage testifies, and why should not the angler have the benefit of so excellent an article? On the score of weight alone it is worth a trial, weight being very important on hot days. The two handles in the middle are not perhaps quite adapted for fishing purposes, but it is quite casy to remove them and attach rings at more eonvenient points to which could be fastened the ends of a shoulder strap. Of course the bass offers no convenienee for earrying tackle and lunch-it is purely a receptacle for fish-but a fishing-coat has, or should have, big pockets, and if they are not enough it is always possible to carry a small haversack as well as the bass. The two together will not weigh so much as a creel or bag whose eapacity would be no greater. I believe that an angler who has once got 
accustomed to a bass will not readily take to any other form of receptacle in hot weather.

In a book of this sort I do not think there is any necessity to go into the minutix of equipment, a matter which has been sufficiently dealt with by many competent pens. A modern catalogue of fishing tackle shows that we have reached a very high standard of efficiency and comfort in regard to our gear. Where development is most probable is in flies. In a previous chapter I have hinted my belief that the new conventions are in fact more true to nature than the old, though the belief does not move me to bonfires or other drastic action. While the trout continue, in their irresponsible manner, to rise at buttereups, cigarette-cnds, defunct lucifer matches, and other poor imitations of the insect kingdom, I believe I shall continue to get as much sport as is good for me with the flies which take my own vagrant fancies from time to time. Those flies may be old, or they may be new. I have no prejudice either way. So there is nothing earnest or useful to be said here.

There are, however, just a few things connected with equipment on which I have definite views, as I am sure that they have had a considerable influence on my fishing. One rclates to reel-lines and it is of more importance to novices than to old hands. When I was a boy I used to do my fly fishing with 
any line - a fly fishing line was, I supposed, a thin one, as opposed to a pike fishing line which was a thick one. Everybody knew, of course, what ravening monsters were those pike, much like crocodiles in fact. I pegged away with my thin lines and used, I remember, to be much bothered when an extra long cast had to be made.

In course of time I was introduced to the dry fly and incidentally to the heavier line which so many of the masters used, and then I got my first understanding of the essence of casting which is the balanee between rod and line, and also of the exeellent deviec of "shooting" a yard or so which saves so much labour. The increase of comfort and case brought about by using a heavier line impressed me so much, that I came to the conclusion (by which I still abide) that no novice ought ever to begin his eareer with a light one. Later, it is a different matter. A light line has many advantages in fishing. But having learnt the mechanies of casting with a heavy one a man has no difficulty in adapting himself to the other. The point is that he should learn in comfort and without tears, and to this end the heavy line (suited to the rod of course) doth marvellously contribute.

I have certain fixed ideas concerning gut also, elementary enough, no doubt, but still from my observations new to some people. 'The wet-fly collarr' 
of these flies for instance is often level. If tapered it follows the convention of a dry-fly cast and tapers very gradually. Both these fashions are, I am sure, a mistake. A level three-yard cast of, say, 3x gut is liable to bad tangles which involve the whole of it, and the top part near the reel-line is apt to get frayed and worn. Also it does not make for such accurate delivery as does a tapered cast.

On the other hand the tapered cast, whose descent from thick to fine is very gradual, offends against rcason for wet-fly work. When three flies are used not less than two feet six inches apart the top dropper will be found depending from gut which is considerably thicker than that to which the end fly is attached. This handicaps the said dropper unreasonably in its presentation to a fish which has an eye for suspicious circumstances, and is quite unnecessary. As I see it a wet-fly collar should cease its taper at a point at least a foot above the top dropper. I find it an advantage to have the collar rather longer than the usual three yards, especially if three flies are to be used, and so to get about four or five feet of taper to about six feet of level.

Another small point-the flies should not be dressed on gut finer than that forming the untapered part of the cast. If they are there is, I think, more risk of breakages, especially with the droppers. Indeed, when using eyed flies as droppers I always attach 
them to links one grade stronger than the end of the cast, as it makes them stand out better and there are less tangles.

The only special point about dry-fly casts, in which my practice seems to differ from that of other anglers whom I mect, is that in calm weather or following winds I use a length which some of them secm to think excessive, eleven or even twelve feet. F. M. Halford recommended this to me as a remedy for cracking-off flies and an aid to delivering them without a bang, and I have found it so helpful that I possibly now carry the plan to extremes. I must own to having sometimes had difficultics in landing trout when a twelve-foot cast has been associated with a ninc-foot rod.

Of the many "tips" which the years have brought to me from one source or another I think the discovery of Amadou, that admirable fungus, is one of the best. The most ingenious fisherman, the late Mr. Basil Ficld, first gave me a small piece of Amadou, but he did not tell me what it was. I got the impression that it was some very scarce and precious material from France. My little piece was worn out in a short time and I mourned it sinecrely for some years. Then one day another most ingenious fisherman, Dr. W. J. Turrell, the authority on old angling authors, led me into a chemist's shop in Oxford and revealed to me great 
heaps of what I had supposed to be about as plentiful as radium. It was a glad moment.

It was still some time, however, before the full merits of Amadou were revealed to me. I used it for drying flies with pleasure and profit, but never thought of further use for it till some correspondent wrote to The Field to suggest that it would prove a remedy for a sodden line. The sinking line had always been one of my chief bugbears in dry-fly fishing, and I used sometimes to cumber myself with a second reel, in case the first failed me after a few hours of casting. But Amadou has quite removed the necessity for that. It will dry a line, so that, after a new application of grease, it will float almost as long as it did when the day began. An admirable fungus indeed.

It is tempting to take up a tackle catalogue and work slowly through its contents, dwelling on the virtues of fly-boxes with transparent lids, on reels with melodious voices, on handy folding-nets, on agate rings, and other excellent devices for increasing the happiness of the angler. But there would really be no end to it, and this book is a thing which, however imperfect in other respects, must, at any rate, be perfect in one-its reader must be able to say at a given point, "Well, that really is all."

This is so important that I will withhold that satisfaction from him no longer. 



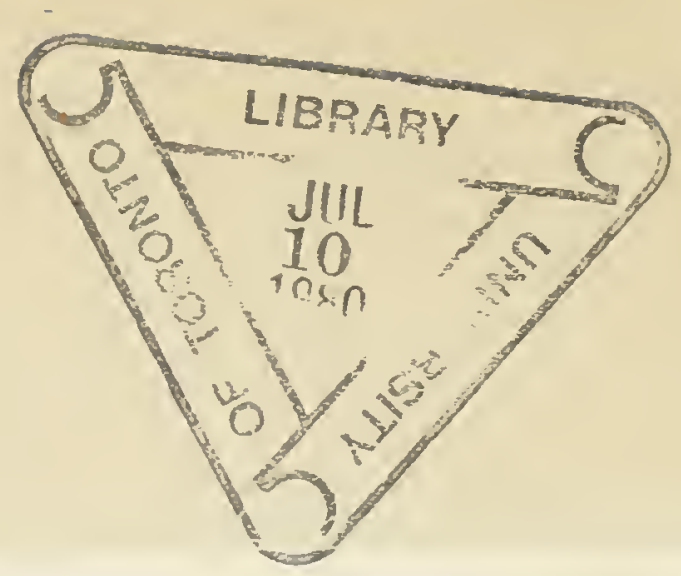

DATE DUE

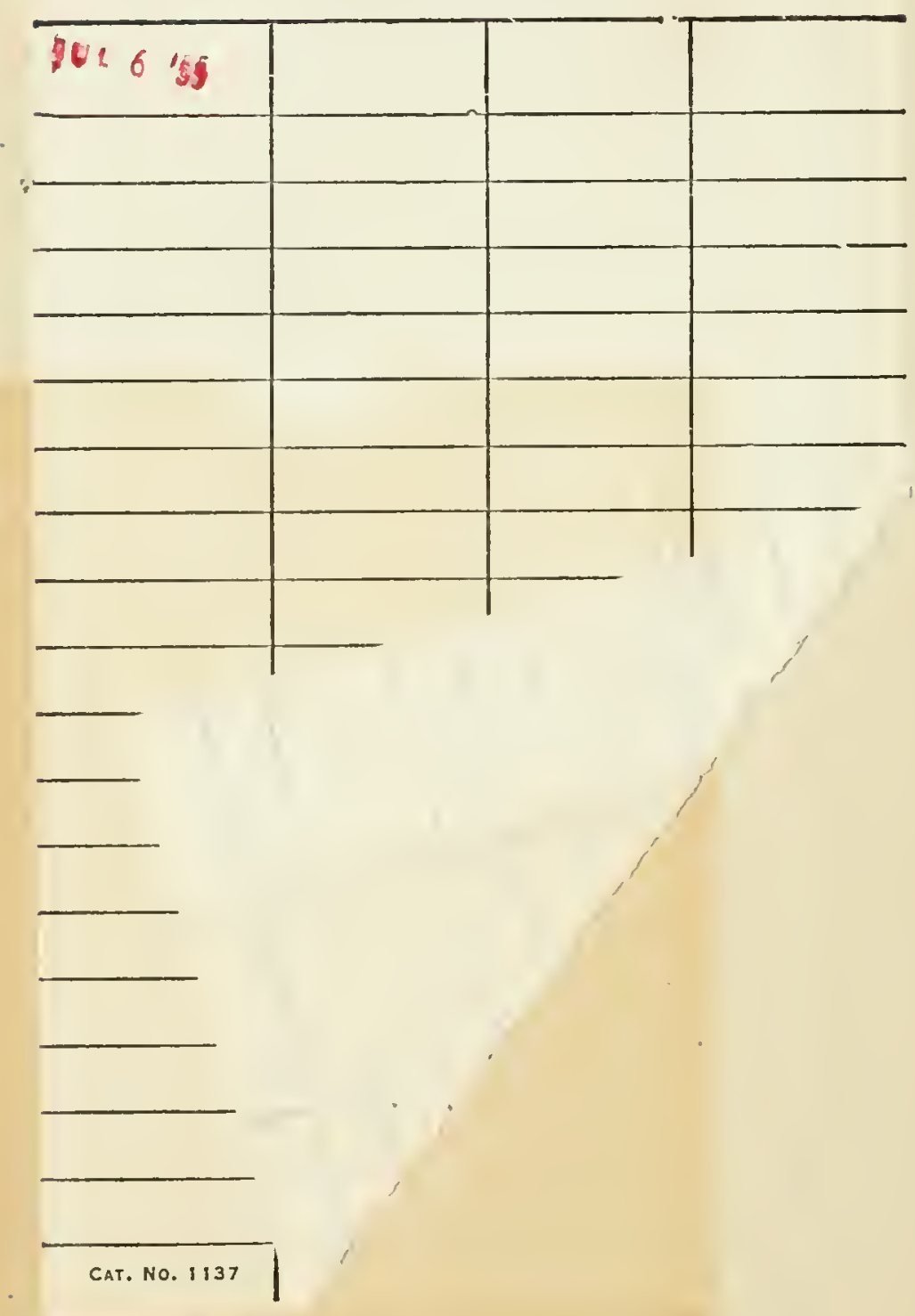




\section{PLEASE DO NOT REMOVE CARDS OR SLIPS FROM THIS POCKET}

\section{UNIVERSITY OF TORONTO LIBRARY}


